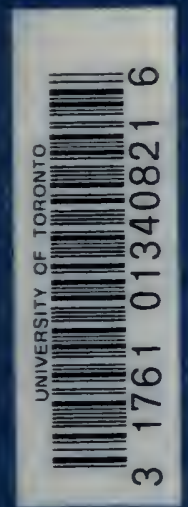


Digitized by the Internet Archive in 2008 with funding from Microsoft Corporation 




\section{RUSTIC SOUNDS}

AND OTHER STUDIES 



\section{RUSTIC SOUNDS}

AND OTHER

STUDIES IN LITERATURE AND

NATURAL HISTORY

BY

SIR FRANCIS DARWIN

With Illustrations

LONDON

JOHN MURRAY, ALBEMARLE STREET, W. 1917 


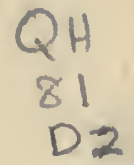

IIBRAR

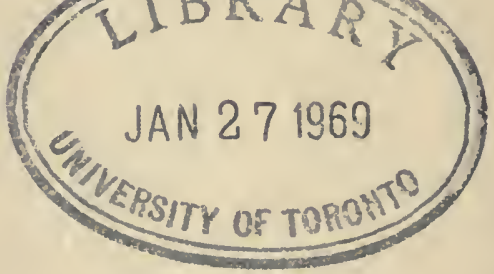




\section{CONTENTS}

PAGE

I Rustic Sounds

$\begin{array}{rrrr}. & . . & . & \text { I } \\ . . & . . & . . & 13\end{array}$

III The Movements of Plants .. $\quad$. 36

IV A Lane in the Cotswolds .. $\quad$. 55

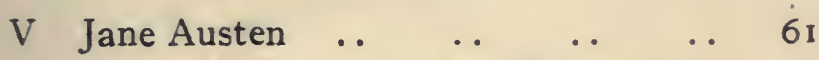

VI The Education of a Man of Science . $\quad 78$

$\begin{array}{lllll}\text { VII The Pipe and Tabor } & \text {. } & \text {. } & \text {. } & 97\end{array}$

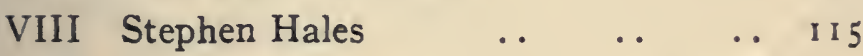

IX Nullius in Verba $\quad \ldots \quad \ldots \quad \ldots \quad 140$

$\begin{array}{lllll}X & \text { Sir George Darwin } \quad \ldots & \ldots & \text {. } & 152\end{array}$

$\begin{array}{llllll}\text { XI War Music } & \text {. } & \ldots & \ldots & \ldots & 195\end{array}$

XII The Teaching of Science .. .. $20 \mathrm{r}$

XIII Picturesque Experiments .. $\quad$.. 210

XIV Dogs and Dog Lovers _. . . 219

Plate. Pipe and Tabor $\quad$. $\quad$.. to face 102 
To

F. H. D. 


\section{RUSTIC SOUNDS}

Sounds are to me more reminiscent than sights ; they bring back the sensations of childhood, and indeed all memories of my past life, in a way more touching and clear than what is seen. Wendell Holmes claims the sense of smell as most closely associated with memory; for me, as I say, it is that of hearing.

In this paper I shall wander in imagination through the different seasons in the home of my youth, and let the recalled rustic sounds lead where they will.

To children there is something impressive and almost sacred in the changes of the seasons, in the onset of winter, or the clear approach of spring. The first of these changes was heralded for me by the appearance of puddles frozen to a shining white; mysterious because the frost had drunk them dry in roofing them with ice, and especially delightful in the sharp crackling sound they gave when trodden on. This was the noise of the beginning of winter. Another winter memory is the humming whistle of the boys' feet as they slid on the village pond, a remembrance that recalls my envious admiration of their heavily nailed boots, giving them an advantage in pace and a more noble style of sliding. 
Another familiar sound was the wicked groaning crack that ran round the solitary pond on which we skated, as it unwillingly settled down to bear us on its surface. It had a threat in it, and reminded us how helpless we were, that the pond-spirit was our master and had our lives in its grip.

Another winter note was the hooting of invisible owls, boldly calling to each other from one moonlit tree to another. In the spring there was the querulous sound of the lambs, staggering half fledged in the cold fields among the half-eaten turnips beside their dirty yellow mothers. Not the sheep of the Dresden shepherdess, but rather of the old man in As You Like It, who warns Rosalind that shepherding has its ugly side. Yet it had something prophetic of more genial days.

IN

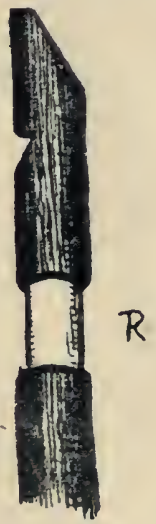

Fig. $r$.

As the sap began to rise in the trees my thoughts lightly turned to the making of whistles. I was taught the mystery by a labourer in my father's employ and never departed from his method. The first thing was to cut a branch of some likely tree, a horse-chestnut for choice, severing it by an oblique cut, removing a ring of bark $R$ and notching it at $N$. The bark had then to be removed in one piece so as to make the tube of the whistle. The first thing was to suck the bark and thoroughly wet it - a process I now believe to have been entirely useless. The bark was next hammered 
all over with the haft of the knife, which was held by the blade. Then when the inner layer of the bark was well bruised, it could be removed in one piece. To effect this I was taught to hold it in my handkerchief, and after a twist or two, a delicious yielding was experienced and the bark slipped off. The shiny white stick which remained in the other hand had to be cut in half, shaved in a particular way and again fitted into its bark tube. Then came the exciting moment,-would the thing whistle? The joy was short lived, and the whistles soon dried and shrank and ceased to satisfy the artist. But it was always possible to make a new one.

Since the above description was written, there has appeared in The Times Literary Supplement (February 22, 1917, p. 90) a notice of the poems of a Canadian writer ${ }^{1}$ from which the reviewer quotes the following beautiful lines:

"So in the shadow by the nimble flood, He made her whistles of the willow wood, Flutes of one note with mellow slender tone;

(A robin piping in the dark alone).

Lively the pleasure was the wand to bruise, And notch the light rod for its lyric use, Until the stem gave up its slender sheath, And showed the white and glistening wood beneath.

And when the ground was covered with light chips, Grey leaves and green, and twigs and tender slips,"

${ }^{1}$ Lundy's Land, and other Poens, by Duncan Campbell Scott, Toronto. 
This could only have been written by one perfectly familiar with the art of whistle-making. But it seems to have been misunderstood by the reviewer, who says that he " once came upon one of these small Æolian harps in a wooded isle in the "Land- of Afternoon,'" . . . and decided "that it was a work of superstition by Indian hands." As an Æolian harp is a stringed instrument sounded by the wind, and a whistle belongs to the very distinct class of musical things sounded by human breath, I can only suppose that the reviewer has misunderstood the poem.

I cannot leave the Canadian poet without a reference to the beautiful line, ("A robin piping in the dark alone.") A Canadian robin must surely make a song like ours, who seems also to sing in parenthesis.

The other form of rustic pipe that pleased me was a sort of oboe made from a dandelion stalk by squeezing it at one end. It had a rough nasal note, which could be controlled by holes cut in the stalk and stopped with the fingers. This again was but brief satisfaction, for the two halves of the reed soon curled outwards and ceased to speak. In later life this curling outwards was made use of in my work in the physiology of plants. I like to remember that my primæval oboe gave me the idea.

The village boys made 'musics' by fixing strips of laurel leaf into a split stick, and blowing violently into them, which set the leaf vibrating and made a coarse scream, but this instrument we despised, and I think rightly, for it had none of the 
pleasant tone of the whistle, nor was there any art in the making of it.

A primæval musical instrument called the 'Whit horn' I have seen in the possession of the late Mr. Taphouse, of Oxford. It is a conical tube of bark held together with thorns and sounded by means of a rough oboe-reed made of bark; there were no finger-holes, and is said to have yielded a harsh shriek on one note. It was, I think, played on May ist, or else at Whitsuntide. It is to Mr. Taphouse that I owe my introduction to the pipe and tabor which form the subject of a paper in this volume. The pipe is shrill in its upper register, but this is no great fault in an instrument meant to be played out of doors: the same fault is to be found with the flageolet, and the penny whistle. But the last named instrument is reminiscent of a man playing outside a London public-house, and we know from the story of the perfidious Sergeant in The Wrong Box to what lengths it may lead us. ${ }^{1}$

The most truly rustic instrument (and here I mean an instrument of polite life-an orchestral instrument) is undoubtedly the oboe. The bassoon runs it hard, but has a touch of comedy and a stronger flavour of necromancy, while the oboe is quite good and simple in nature and is excessively in earnest; it seems to have in it the ghost of a sunburnt boy playing to himself under a tree, in a ragged shirt unbuttoned at the throat, a boy created by Velasquez. To

1 I have an antiquarian interest in the penny whistle as being a poor relation of the "recorder" of our forefathers. 
hear an oboe actually played as a rustic instrument one must go to Brittany, where it accompanies the national bagpipe or 'biniou.' To a reed-instrument player it was painful to see the oboist bite a bit off his reed when the tone was not to his liking!

From this digression, originating in the whistle cut from a horse-chestnut bough, I return to some less artificial sounds. I must say a word about the song of birds, but my knowledge of the subject is but small. The most obvious of spring-time sounds is the voice of the cuckoo. I confess to liking the muttering chuckle which, in an unscientific mood, I have supposed to mean that an egg has successfully been laid in a hedge-sparrow's nest. But the cuckoo's "word in a minor third" is always delightful. The bird is neither more nor less of a foreigner than a willow-wren, yet he has, in comparison to the wren's subdued chromatic warble, a song so self-assertive, and a tone so unlike our other birds, that one feels him an obvious exotic, a foreigner of so glorious and dashing a nature that one is grateful to him for singing among flat ploughed lands and monotonous hedges. I fancy the Welsh proverb, "Who would have thought the cuckoo would sing on the turf-heaps of the mountains," is a poetic reflexion of this thought.

Of the nightingale I have nothing to say, except to put on record a true remark of Sir Charles Stanford's, viz., that he sings in a syncopated rhythm. But, though I lived in a nightingale land, it is another bird that most clearly brings back to me the country of my boyhood, I mean the night- 
jar. He has something of antique mystery which I do not find in the nightingale, as he purrs on his only note through the warm night. There is something unknown and primæval and vaguely threatening in his relentless simplicity. Can it be that I inherit from a stone-age ancestor both the fear and love of the bull-roarer?

Another bird that moves one in a very different way is the robin, of whom it is hard to say whether he has more of tears or smiles in his recitative. In comparison to the night-jar he seems like a civilised human soul who has quite modern sorrows, and has half forgotten them in quiet contentment with the autumn sunshine. The blackbird has a tinge of the robin's sentiment, but it is over-borne by the glory of his song as a whole, which is pure gold, like his beak.

The chaffinch is not an interesting person, and he is so numerous that one soon becomes weary of him and his song. Let us hope that he expresses his real nature in the building of his pretty nest rather than in song. This must, I think, often happen, and to take an example from human builders, it is not inconceivable that the architect of St. John's College Chapel, Cambridge, may have sung delightfully. But there are limits to one's faith, and personally I cannot imagine the desecrator of Pembroke College in the same injured town of Cambridge practising any art in a way that would please me.

To return to birds - the greenfinch is a pleasant singer, or perhaps a conversationalist. I am never tired of hearing him repeat the word "Squeese" as 
he sits hidden in the heavy shade of the summer elms. His twinkling bell-note with its contented simplicity is also attractive. His cousin, the bunting, makes remarks not unlike those of the greenfinch; and he appears to address them by preference to the travellers on dusty high roads, where he passes much of his time sitting on telegraph wires. The anchorite yellow-hammer persistently declining cheese with his bread is always pleasant. Professor Newton used to say that the spring begins with the yellow-hammer's song. According to Blomefield's Calendar ${ }^{1}$ the average date in Cambridgeshire is February 16 , but he has been known to sing on January 30-rather a wintry beginning for spring. I have never made up my mind as to what the kitty-wren says or sings. He is always in a desperate hurry to get through his piece, as if he were afraid of lagging behind the beat of some invisible conductor. In consequence of this there is a want of restraint, and a style that suggests a shy child gabbling a show bit of poetry. But I repent these words for I love the kitty-wren.

There are a multitude of other bird-sounds which are pleasant to hear as their turn comes round, for instance, the complaint of the wryneck, the "cuckoo's mate," who seems to me to be querulously expressing his dislike to my garden, which he tries year after year and deserts after a day or two.

I have never heard that contented bird the

1 A Naturalist's Calendar, by Leonard Blomefield (formerly Jenyns). Cambridge University Press, 1903. 
quail, who should be a wholesome lesson to all wrynecks. I should like to hear him as Schubert has him:

\section{"Sitzend im Grünen \\ Mit Halmen umhüllt,"}

and singing "Lobe Gott" all day in the rhythm with which the oboe praises God in the Pastoral Symphony.

Another bird, whom I take for a contented fellow, is the green woodpecker, for he goes through life laughing, but I am not quite sure that I should like his taste in jokes. $\mathrm{He}$ is always associated in my mind with a passage in a letter of my father's : "At last I fell fast asleep on the grass, and awoke with a chorus of birds singing around me ; and squirrels running up the trees, and some woodpeckers laughing, and it was as pleasant and rural a scene as ever I saw, and I did not care one penny how any of the beasts or birds had been formed."1

There are many noises rather than notes which are most pleasant to hear. The invisible industrious corncrake, whose persistent cry comes from nowhere and everywhere at once. The harsh warning of the jay who seems to say "Man! man!" as he skulks off when his wood is invaded. The rough noise of the ox-eye sharpening his little saw, and many others.

Then I must not forget the noise of birds in flocks, ranging from the familiar wrangle of sparrows noisily going to roost, to the mysterious sound of

${ }^{1}$ Life and Lefters, Vol. II., p. II4. 
great flights of birds migrating at night, one of the most romantic of sounds, but to me untranslatable, since I do not know the language of these wanderers.

I come now to human sounds. It was exciting to wake at $5 \mathrm{o}^{\prime}$ clock some morning in June, and to learn by the sound of scythes being whetted that the mowers had arrived, and that the hay harvest had actually begun. The field had been a great sea of tall grasses, pink with sorrel and white with dog-daisies, a sacred sea into which we might not enter. But now we could at least follow the mowers, and watch the growth of the tracks made by their shifting feet, and listen to the swish of the scythes as the swathes of fallen grass and flowers also grew in length. There was something military in their rhythm, and something relentless and machine-like in their persistence. But our admiration was mixed with pity from the time that one of them told us that after the first day's mowing he was too tired to sleep. In later years another sound was associated with haymaking, when in an Alpine meadow the group of resting peasants were heard hammering the blades of their little preRaphaelite scythes to flatten the dents made by stones hidden among the grass.

A well-remembered sound that came near the end of the harvest was the cry of "Stand fast!" which was heard at intervals warning the man in the cart, whose duty it was to arrange the pitched-up hay, that a move was to be made. Why it was necessary to shout the warning so that it could be heard a quarter of a mile away I cannot say. But its impressive effect depended 
on its loud chant-like tone. This sound is connected with recollections of riding in the empty hay-cart, from the sea-green stack mysteriously growing in the corner of the field back to where hay waited to be carted. The inside of the hay-cart was enchantingly polished, and also full of hay-seed, which had a charm for me. The hay-making at Down was a leisurely affair, with many women gossiping as they gently turned the hay. There was, however, one man of whom we children were much afraid, a fierce red-eyed old labourer who acted as foreman, and did not hesitate to show that he thought us out of place in a hay-field.

One sound there was peculiar to Down,-I mean the sound of drawing water. In that dry chalky country we depended for drinking-water on a deep well from which it came up cold and pure in buckets. These were raised by a wire rope wound on a spindle turned by a heavy fly-wheel, and it was the monotonous song of the turning wheel that became so familiar to us. The well-house, gloomily placed among laurel bushes, had a sort of terrifying attraction for us, and I remember dropping pebbles and waiting -it seemed ages-for them to fall into the water below. We believed the well to be 365 feet deep, also that this was the height of the dome of St. Paul's-I have never tested the truth of either statement. The opening was roofed in by a pair of hinged flaps, or doors, and I especially liked the moment when the rising bucket crashed into the doors from below, throwing them open with a brutal and roystering air, which one forgave it as having made a long and dangerous journey 
up from the distant water. But the best was when the empty bucket went down, and the fly-wheel spun round till its spokes were invisible. Then was the time to remember the death of a dog (called Dick) who was killed by jumping through the flying wheel. I envied my elder brothers who could actually remember Dick : to me he was only a tragic myth. I imagine that in hot dry weather more water was drawn, or else that being more constantly out of doors we heard more of it. It is at least certain that the sound of the well came to be associated with peaceful days and happy weather in that dear garden.

Another sound I like to recall is connected with the memory of my father. He daily took a certain number of turns round a little wood planted by himself, and christened the Sandwalk. As he paced round it he struck his heavy iron-shod walking-stick against the ground, and its rhythmical click became a familiar sound that spoke of his presence near us, and was associated with his constant sympathy in our pursuits. It is a sound that seems to me to have lasted all those years that stretch from misty childish days until his death. I am sure that all his children loved that sound.

February, 1912. 
II.

\section{FRANCIS GALTON ${ }^{1}$}

\section{$1822-1911$}

Francis Galton was born on February 16th, ninety-two years ago, and to-day we are met together to remember him-a word that seems to me more in tune with his nature than the more formal expression commemorate.

He disliked pomposity, but he seems to have loved little private ceremonials. For instance, when he opened the first notebook in preparation for his autobiographical Memories, he began page I with Falstaff's words : "Lord, Lord, how subject we old men are to this vice of lying "-an inverted appeal to truth which no man ever stood less in need of. And again, at the foot of the very last page of his Memories is a drawing of Galtonia candicans, a little ceremony without words, a hieroglyphic glorification of the honour paid him in giving his name to this African plant.

Many persons, and even some reviewers, form their opinions of books by reading half-a-dozen passages at random. I have been more scientific in selecting the first and last pages, and from these I conclude that a simple and kindly commemora-

1 This, the first Galton Lecture, was delive:ed before the Eugenics Education Society, February r6th, 1914, and is, by permission. reprinted, with some changes, from the Eugenics Review, I9I4. 
tion is not out of harmony with the genius of this great and loveable man.

I should like to express my appreciation of the honour done me in asking me to give the first Galton lecture. In many ways I am a bad choice, since I have had no share in his science of eugenics, neither has my research-work been directly connected with evolution. I can only hope that in consideration of my delight in the fibre and flavour of Galton's mind, with its youth, its charm of humour, and its ever-springing originality and acuteness,-I say that I hope these considerations may excuse me for having undertaken an office for which I am in so many ways unfitted.

One of his most obvious characteristics was his love of method. I do not mean methodicalness, but that he took delight in knowing how to do all manner of things in the very best way. He also liked to teach his methods to others. Those who never saw him, or even read his books, will exclaim, "What a bore he must have been." One might as well call the lightning a bore for explaining that the thunder was coming, or complain of the match for boring the gunpowder as to the proper way of exploding. With Galton's explanations there was a flash of clear words, a delightful smile or gesture, which seemed to say: "That's all-don't let me take up your time." Nobody was ever more decidedly the very antithesis of a bore than Francis Galton.

He first appeared on the literary and scientific stage as a traveller, geographer, and author of a book on South Africa (1853), and it was the experi- 
ence there gained that enabled him to write two years later, in 1855, that wonderful book, The Art of Travel. There he teaches such vitally important things as how to find water, how to train oxen as pack animals, to pitch a tent, to build a fire, to cook, and a thousand other secrets. He liked, of course, to be useful to weary and thirsty travellers, but he was as much, or more, impelled by the love of method for its own sake. $\mathrm{He}$ was in fact an artist in method. The same thing is shown in a letter he wrote to Nature near the end of his life, explaining how to cut a cake on scientific principles so that it shall not become stale. This again was not so much a philanthropic desire that his fellow men should not have dry cake, as delight in method.

When I re-read The Art of Travel quite recently, I could not find his method of preventing a donkey braying. My recollection is that, observing a braying donkey with tail erect, he argued that if the tail were forcibly kept down, as by tying a stone to it, the braying would not occur. I certainly believe myself to have read or heard that this most Galtonian plan succeeded.

Later in life he tried to make his unique knowledge of value to his country. He writes ${ }^{1}$ :

"The outbreak of the Crimean War showed the helplessness of our soldiers in the most elementary matters of camp-life. Believing that something could be done by myself towards removing this

1 The passage quoted is from Galton's autobiographic Memories, page 165 . I have necessarily drawn largely on this delightful book, and have not generally thought it necessary to give references. 
extraordinary and culpable ignorance, I offered to give lectures on the subject, gratuitously, at the then newly-founded camp at Aldershot."

He received no answer from the War Office, but a personal application to Lord Palmerston led to his being installed. He speaks of a few officers attending his course, and adds that the "rude teachings of the Crimean War soon superseded" his own.

In relation to what I have been speaking of, I must here be allowed to turn back to an earlier period of his life. In illustrating the different dispositions of his sisters, both of whom were dear to him, Galton writes :

"My eldest sister was just, my youngest merciful. When my bread was buttered for me as a child, the former picked out the butter that filled the big holes, the latter did not. Consequently I respected the former, and loved the latter."

Have we not here an early appreciation of method, or must we merely class the memory with the scene in "Great Expectations," where the terrifying elder sister, Mrs. Joe, prepares bread and butter for her husband and for Pip (her little brother) in an eminently just and disagreeable manner. May I be allowed to add that a love of butter in the big holes is not hereditary in all branches of the family; I should have loved the sister who picked it out.

At a later stage in his boyhood Galton transferred his study of method from his sisters to his schoolmasters. He describes what he suffered from the absurd limitations (which still exist) in the education of English boys, and chafed at the 
teaching he received. "Grammar," he says, "and the dry rudiments of Latin and Greek were abhorrent to me, for there seemed so little sense in them." He suffered in fact like his cousin, Charles Darwin, who groaned over the classics at Shrewsbury School, and forgot what he learned, even to some of the Greek letters, by the time he was nineteen.

In 1838 , when Galton was sixteen years of age, he became an indoor pupil at the Birmingham General Hospital. Here the education was at any rate practical enough, and to this coddled generation it sounds a rough introduction to medicine. He had to prepare tinctures, extracts, decoctions, and learned to make pills by hand-a slow enough process. In later life, when he saw a pill-making machine at work, it must have been his boyish memories which inspired the characteristic calculation that if a grandmotherly Government possessed forty-five of these engines, it could supply each inhabitant of the British Isles with one pill per diem.

It was in the surgery that he had most experience; he and the other indoor pupils were called up at all hours to dress burns, to patch broken heads, and reduce dislocations, with, as it seems, very little instruction. It was doubtless a fine bit of education in self-reliance, and he must have learned much that was of use in his South African travels. Whether as a student of method he approved of his rough and ready education is not quite clear. His genius for experiment, or rather that priceless capacity for extracting unexpected conclusions from experience, comes out in his 
account of a case in the Birmingham Hospital. An injured drayman was brought in dead drunk, and underwent amputation of the legs without any signs of feeling pain. This set Galton wondering whether patients might not with advantage be made drunk before operations-a query which was to be happily answered by the discovery of anæsthetics.

Another characteristic event was his attempt to learn the properties of all the drugs in the pharmacopceia by personal experience. He determined to dose himself alphabetically, but got no further than $\mathrm{C}$., for the effects of croton oil put a stop to his thirst for first-hand knowledge.

We must pass over his time at King's College, London, where, as he sat at lecture, he could see the "sails of the lighters moving in sunshine on the Thames," a vision which stirred his blood with a longing for adventure, and which, as he characteristically noticed, always occurred when the weather-cock on the Horse Guards showed that the south-west wind was blowing.

We must, in like manner, skip his undergraduate days at Trinity, Cambridge. We thus arrive by a devious route at the period when he returned a traveller and geographer of recognized merit, and began the work with which he was practically connected for many years, as a member of the Meteorological Committee. His best-known contribution in the science was in a paper read before the Royal Society in 1862, where his discovery of the anticyclone was first described; but he also had a good deal to do with the printing and publish- 
ing of the now familiar weather charts. Meteorology takes us from 1861 to 1863 , that is nearly to 1865 , when his first paper on heredity appeared, which was at the same time his first paper on hereditary genius. This line of research was to form his chief claim to celebrity and must be separately treated.

Meanwhile I wish to say something of his love of experiment, which is a branch of his devotion to method. We know something of the more entertaining of his inquiries from his delightful book of Memories, yet I cannot but fear that he has left out many experiments even stranger than those he publishes. My father had a special affection for what in his own case he called "Fool's experiments." These are what, I am afraid, Galton may have omitted. Still there are records of some delightful lines of work. He is probably the only man who ever attempted to solve by experiment the problem of free will and determinism. He limited his inquiry to the question-whether there exists in human affairs such a thing as an "uncaused and creative action." The experiment, or rather selfobservation, was carried on (1879) for six weeks, almost continuously, and "off and on for many subsequent months." He found that with practice he could nearly always trace the "straightforward causation" of a given action, which at first seemed to have been performed "through a creative act, or by inspiration."

Then there was his attempt to experience the feelings of the insane. "The method tried was to invest everything I met, whether human, animal, or inanimate, with the imaginary attributes of a 
spy." The trial was only too successful ; by the time he had walked $1 \frac{1}{2}$ miles to the cab-stand at the east end of the Green Park "every horse in the stand seemed watching" him, "either with pricked ears, or disguising its espionage." $\mathrm{He}$ adds that hours passed before this uncanny sensation wore off. On another occasion he managed to create in his mind the feelings of a savage for his idol, the idol in his own case being a picture of Mr. Punch.

These experiments seem to me very characteristic of the man in their originality, their humour, and their unexpected measure of success, for personally, I should have prophesied failure in all. They have a special bearing on Galton's belief that a quasi-religious enthusiasm for eugenics may be built up. I have sometimes wondered that he should believe this great change so feasible, but I understand how he came to think so when I read of his strange power of impressing beliefs on himself, with such force as to leave a trail of discomfort in the mind after the make-believe had ceased.

These and similar trials were, I think, made in relation to his desire to weigh and measure human faculty in a broad sense. I remember his telling me of his experiments on the mind of the British cabman. His method was to use alternately two different forms of the address to which he wished to go. Thus on Monday he would tell the man to drive him home to 42 , Rutland Gate, on Tuesday he would say, "Rutland Gate, 42," and so on. My recollection is that the cabmen understood more quickly the familiar formula in which the number precedes the name of the street. 
There was also a characteristic experiment or inquiry into the intensity of boredom in a lecture audience, by counting the number of fidgets per man per minute. In this case to avoid the open use of a watch, he estimated time by the number of his own breaths, "of which there are fifteen in a minute." I hope my brother ${ }^{1}$ will forgive my adding that he found the Royal Geographical Society meetings good hunting-ground for fidgets, for as Francis Galton remarks, "Even there, dull memoirs are occasionally read.'

Nor must I forget his plan of marking, by means of a hidden apparatus, the beauty of the women he met in the streets of different towns. He classified them as pretty, ugly, and indifferent; in this beauty competition London came out at the top; Aberdeen, I regret to say, was at the bottom.

But in considering the measurement of human faculty we have got quite out of any reasonably chronological sequence, for the book bearing that title appeared in 1883 . But the estimation of human characteristics, especially in relation to heredity, was in Galton's mind several years earlier, and in 1865 he wrote the two papers in Macmillan's Magazine which contain the germs of his later work on heredity and eugenics. It is unfortunate that the research on heredity, together with its practical application to human welfare in the new science of eugenics, should not have more space given to it in his autobiographical Memories; there are but

1 Major L. Darwin had been President of the Royal Geographical Society. 
thirty-seven pages-or i I per cent. of the whole book. The specific importance of the subjects here dealt with is so great that these thirty-seven pages outweigh all the rest of the book. We should like to have had a fuller account by the author of this remarkable work of 1865 . He does, however, tell us-and it is a very striking statement-that the two articles "expressed then, as clearly as I can do now, the leading principles of Eugenics."

The chief point in which he came to differ from the Macmillan articles was that he was then "too much disposed to think of marriage under some regulation, and not enough of the effects of self-interest and of social and religious sentiment." I imagine that the pendulum has now swung the other way, and that one of the most hopeful and practical schemes is the prevention of marriage among habitual criminals and the feeble-minded.

Galton attributes his work in heredity in some measure to the publication of the Origin of Species, which, he says, "made a marked epoch" in his "mental development, as it did in that of human thought generally."

That Galton personally felt no difficulty in assimilating the new doctrine, he characteristically ascribes to a "bent of mind that both its illustrious author" and himself had "inherited from" their "common grandfather, Dr. Erasmus Darwin." But in our day the name of Galton is intimately connected in our minds with the science of heredity, and we forget that he, like lesser men, was a mine fired by the Origin. He was "encouraged," he says, "by the new views to pursue many inquiries 
which had long interested" him "which clustered round the central topics of heredity." This was the charge with which the mind had been loadedthe Origin was the fuse.

When that book was published in 1859 , nearly everyone here to-night must have been too young to know anything of the great change in the colour of human thought which was ushered in. There are more who may remember how twelve years later, when the Descent of Man came out, there was still plenty of clerical and other forms of foolish bitterness. But a man needs to have been in the full swing of mental activity in 1859 to perceive the greatness of the change due to the Origin of Species.

His two papers in Macmillan's Magazine, 1865 (Vol. XII., pp. 157 and 318), seem to me very remarkable, and, as I have said, they are passed over too lightly by the author in his Memories (p. 310). They contain a statistical proof of the inheritance of intellectual and moral qualities. ${ }^{1}$ And those who would allow the truth of this statement must further agree that it is the first statistical demonstration of this important fact that the world has seen. And he insists that the whole spiritual nature of man is heritable, so that in his opinion there are no traces of that new element, "specially fashioned in Heaven," which (he says) is commonly believed to be given to a baby at its birth.

The paper contains a very interesting discussion on the development of social virtues by natural

1 In Memories, p. 310 , he criticises the statistical methods of this work. 
selection. He gives, too, a characteristic explanation of that human attribute commonly known as Original Sin, the quality, in fact, which makes men yield to base desires against and in spite of their sense of what is right. He says" that here "the development of our nature under Darwin's law of natural selection has not yet overtaken the development of our religious civilisation." It may be more briefly described as the conflict between the individual desires with the tribal instincts. It must be remembered that for all this discussion Galton had no Descent of Man to guide him.

I shall come back later to his clear and courageous statement of eugenics in 1865 . Meanwhile I must speak of heredity, a word, by the way, introduced by Galton, and for which he seems to have been taken to task.

With regard to the machinery of reproduction the essay is remarkable for containing what is practically identical with Weismann's continuity of the germ-cell, and Galton's priority is acknowledged by that author. But in science the credit goes to the man who convinces the world, not to the man to whom the idea first occurs. Not the man who finds a grain of new and precious quality, but to him who sows it, reaps it, grinds it and feeds the world on it. This is true of this very Macs millan's Magazine article. Who would know of these admirable views on Hereditary Genius and Eugenics, if this were Galton's only utterance? This is the grain which has increased and multi- 
plied : and it is to-day familiar nutriment, and is now assiduously cultivated by the Eugenics Education Society. But if Natural Inheritance, and Hereditary Genius had not been written; if the papers on eugenics had not appeared, and especially if he had not convinced the world of his seriousness by creating a eugenic foundation at University College, where his friend Professor Karl Pearson carries on the Galtonian traditions-why then the paper in Macmillan would have counted for very little. But it was not quite unnoticed. By my father it is referred to in the Variation of Animals and Plants under Domestication. Galton was encouraged and reassured by Darwin's appreciation of his work : his words in Hereditary.Genius ${ }^{\mathbf{1}}$ are, "I feel assured that, inasmuch as what I then wrote was sufficient to earn the acceptance of $\mathrm{Mr}$. Darwin... the increased amount of evidence submitted in the present volume is not likely to be gainsaid." He was characteristically generous in owning his debt to the author of the Origin of Species, and characteristically modest in the value he ascribed to my father's words.

The book on Hereditary Genius strikes me as most impressive. It seems as though the men whom the world had agreed to honour as an admirable and indeed a brilliant worker in geography and meteorology had suddenly grown big. He shows himself to have the power of sustaining a weighty argument in strong and temperate phrase, speaking as judge rather than advocate, and to have definitely

${ }^{1}$ Heroditary Genius, p. 2. 
taken rank with Darwin, Lyell, Hooker and Huxley, men whose pens have dinted the world, leaving their ineffaceable mark on the road trodden by the march of science.

When I was working at the Life and Letters of Charles Darwin, I naturally asked Mr. Galton for leave to publish the letters he had received from my father. But he would not agree. Mr. Darwin, he said, had spoken far too kindly of his work, and he preferred to keep the praise to himself. But later, when he wrote his Memories, ${ }^{1}$ he fortunately realised that it is wiser to think of the value to the world of such documents, than of private likes or dislikes. The letter my father wrote about Hereditary Genius which Galton says "made him most happy" begins :

"I have only read about 50 pages of your book ... but I must exhale myself, else something will go wrong in my inside, I do not think I ever in all my life read anything more interesting and original."'2

In reading this great book it is, I think, impossible to doubt the strength of the work. The quiet relentless way in which his territory is pegged out, and the clear wisdom with which the terms of the new science are defined, are equally impressive. And for lighter enjoyment his illustrations are to be recommended. He has to settle precisely what he means by a man being eminent or illustrious before he can begin to ask-are these

1 He had already allowed Professor Seward and myself to publish them in More Letters of Charles Darwin.

2 Memories, p. 290. 
qualities hereditary? An eminent man is one in four thousand, and to make clear what this implies, he writes: "On the most brilliant of starlight nights there are never so many as 4000 stars visible to the naked eye at the same time; yet we feel it to be an extraordinary distinction to a star to be accounted as the brightest in the sky." 1 If we could imagine that each new night shows us a fresh set of stars, we might speculate as to how many nights we should watch the sky before we found one bright enough for a Galton.

In the same way he tries to make us see a million, because in that number there is but one illustrious man. He worked it out in Bushey Park, where he had gone to see the horse-chestnuts in flower, and came to the astonishing conclusion that, taking one half only of the avenue and the flowers visible on the sunny side of that row, it would require 10 miles of avenue to give $1,000,000$ spikes of blossom.

Later he defines mediocrity in a way not very flattering to those, who, like myself, live in the country. Mediocrity ${ }^{2}$ then "defines the intellectual power found in most provincial gatherings, because the attractions of a more stirring life in the metropolis and elsewhere are apt to draw away the abler classes of men, and the silly and imbecile do not take a part in the gatherings." On this last point, by the way, I am not convinced. The research on the heredity of mental and moral characters

1 Hereditary Genius, p. 9.

2Ibid., p. 31. 
leads naturally to eugenics, as in the 'Macmillan ' paper of 1865 . But before dealing with this I must say a few words about what, in the opinion of some, is Galton's chief claim to eminence-the study of heredity as a whole. There is no doubt that he was the first to treat thoroughly and in a strict statistical method, the steps by which one generation passes into the next. He was pre-eminently a lover of statistics, he was indeed what Goschen called himself, " a passionate statistician."

He used Gauss's Law of Error, which Quetelet had already applied to human measurements. "The primary objects," he says, "of the Gaussian Law of Error were exactly opposed, in one sense, to those to which I applied them. They were to get rid of, or to provide, a just allowance for errors. But these errors or deviations were the very things I wanted to preserve and to know about."

This conception of variation impressed him deeply, so that he remembered the exact spot in the grounds of Naworth Castle where it first occurred to him "that the laws of heredity" were solely concerned with deviations expressed in statistical units."

What may be called the final result of Galton's work in heredity is, I imagine, his ancestral law, namely that "the average contribution of each parent" to its offspring is one quarter, or in other words, that half of the qualities of the child can be accounted for when we know its father and mother. In the same way the four grandparents together

1 Memories, p. 305. 
contribute one quarter, and so on. He illustrates this by calculating how much Norman blood a man has who descends from a Baron of William the Conqueror's. Assuming that the Baron weighed 14 stone, his descendant's share in him is represented by $\frac{1}{50}$ grain. ${ }^{1}$

This side of Galton's work is, in the judgment of many, his greatest claim to distinction as a master in the science of heredity. How far this is so I shall not attempt to pronounce. It is possibly still too soon to do so. Nevertheless, it seems to me that Mendelism, the main facts of which are no longer in dispute, will compel the world (if it has not already done so) to look at variation in a very different way to that of Galton. The Mendelian does not, and never will, look at variation merely as a "deviation expressed in statistical units." Nor can he accept the ancestral law, because he has convinced himself that some ancestors contribute nothing in regard to certain characters.

The contrast between Galtonism and Mendelism may be illustrated by an example, which, if not a strict analogy, has in it something illuminating, especially for those who do not know too much of the subject. Galton seems to me like a mediæval chemist, while Mendel is a modern one. Galton can observe, or can follow the changes that occur when two compounds are mixed. But he knows nothing of the mechanism of what occurs. But the Mendelian is like a modern chemist who calls

1 Macmillan's Magazine, xir., p. 327. 
the chemical elements to his aid, and is able to express the result of the experiment in terms of these elements. This is an enormous advantage, and if my analogy is to be trusted, it would seem as though a progressive study of heredity must necessarily be on Mendelian lines.

But it obviously does not follow that the laborious and skilful work of Galton and his school is wasted. Those who wish to have made plain to them how Biometrics may illuminate a problem which cannot as yet be solved in Mendelian fashion, should read Dr. Schuster's most interesting book on eugenics. I am thinking especially of the question as to the heredity of tuberculosis and cancer. The relation between Galtonism and Mendelism is also well and temperately discussed in the late Mr. Lock's Recent Progress in the Study of Variation, 1906.

But it is time to speak of Galton as a eugeniston which if we look to the distant future his fame will rest. For no one can doubt that the science of eugenics must become a great and beneficent force in the evolution of man.

We must be persistent in urging its value, but we must also be patient. We should remember how young is the subject. As recently as I90 I Galton was, in his Huxley Lecture, compelled to speak of eugenics in these terms ${ }^{1}$ :

"It has not hitherto been approached along the ways that recent knowledge has laid open, and it occupies in consequence a less dignified position in

1 Essays in Eugenics, p. I. 
scientific estimation than it might. It is smiled at as most desirable in itself, and possibly worthy of academic discussion, but absolutely out of the question as a practical problem." After explaining that the object of his discourse was to "show cause for a different opinion," he goes on with what, in his restrained style, is strong language : "I shall show that our knowledge is already sufficient to justify the pursuit of this perhaps the grandest of all objects."1

At the close of the lecture he speaks out as to the difficulties and the pre-eminent value of eugenics, and once more of the oppressive "magnitude of the enquiry."

No one who reads this lecture of Sir Francis Galton's is likely to let eugenics go with a smile, and a remark that it is not a practical problem. It is one of the functions of the Eugenics Education Society to spread the sanely scientific views here set forth by Galton, and as far as I am able to judge, the Society has and is doing sound work in this direction.

In another essay, ${ }^{2}$ Galton discusses the meaning of the 'eu' in eugenics in a characteristic way. He imagines an attempt among the animals in the Zoological Gardens to establish a code of absolute morality. With customary love of detail he supposes the inquiry to be undertaken by some animal, such as a sparrow or a rat, which is intelligent and has easy access to all the cages, and is therefore

'Essays in Ewgenies, p. I.

${ }^{2}$ Ibid., p. 35. 
able to collect opinions. There would be strongly pronounced differences between the carnivorous animals and those which form their natural prey. There would be a general agreement as to maternal affection, though fishes and the cuckoo would laugh at it. But all would agree on some eugenic principles: That it is better to be healthy and vigorous than sickly and weak-well-fitted for their part in life rather than the reverse-in fact, good specimens of their kind whatever that kind may be.

Sir Francis Galton goes on to give a list of qualities that "nearly every one except cranks would take into account in picking out the best specimens of his class." The list includes " health, energy, ability, manliness and courteous disposition." 1 I wish he had thought of eugenic mothers, and had translated manliness into the feminine equivalents of courage and endurance. When I first read this list it struck me at once how highly distinguished was Galton himself in all these qualities. As we dwell on the qualities one by one, they seem to call up echoes from the image we have of his character. "Ability, manliness, and courteous disposition," how strong these were in him! I cannot help feeling that he might have added one more quality from his own treasure-house, namely, a sense of humour, which is so priceless an antiseptic to sentimentality, and was markedly present in his character.

In this same lecture ${ }^{2}$ Galton sums up the

1 Essays in Eugenics, p. 37.

${ }^{2}$ Ibid., p. 42. 
stages in the development of eugenics (1) "It must be made familiar as an academic question." As a practical subject worthy of serious consideration. (3) It must be "introduced into the national conscience, like a new religion." $\mathrm{He}$ recapitulates in an eloquent phrase: "It has, indeed, strong claims to become an orthodox religious tenet of the future, for Eugenics cooperates with the workings of Nature, by securing that humanity shall be represented by the fittest races. What Nature does blindly, slowly, and ruthlessly, man may do providently, quickly, and kindly."

Here we see the future of eugenics marked out for us, and the last sentence might well serve as a motto for this Society. How are we to work for the cause?

It is true that our opinions are formed by the daily papers, and our actions as a nation are determined by political parties which come and go largely by chance. But however our opinions originate, if they are strongly and persistently urged by a large majority of Englishmen, great changes in the manner of human life may be effected. Persistence is the great thing in all reforms: in the words of my father's favourite quotation- "It's dogged as does it." Francis Galton has been temperately persistent in a marked degree. His caution and wisdom are illustrated by the dates of his writings on eugenics and heredity, which placed in order suggest a regiment relentlessly advancing, not a bunch of heroes rushing on a breach:- 
Two papers in 'Macmillan's Magazine' $\mathbf{1 8 6 5}$ Hereditary Genius ～. . . . $\quad$. . 1869

'Fraser's Magazine' $\quad$. $\quad$. . $\quad \ldots \quad 1873$

Human Faculty (word 'Eugenics' first

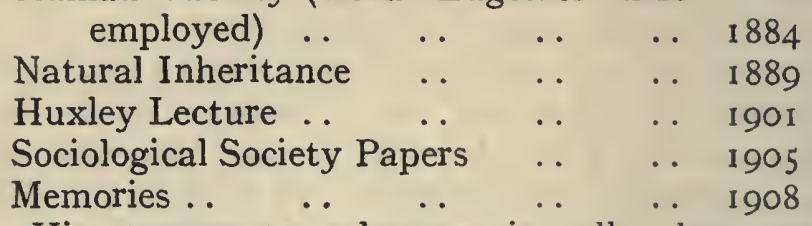

His temperate advance is all the more striking when we remember the fiery impatience with which in Hereditary Genius he spoke of the harm done by the Church in ordaining that the intellectuals, the literary, and the sensitive should be celibates, and of the wholesale slaughter by the Holy Inquisition of the courageous and clear minded who dared to think for themselves.

From the first he had the support of Charles Darwin, who never wavered in his admiration of Galton's purpose, though he had doubts about the practicality of reform. His hesitation in regard to eugenic method is expressed with a wise proviso as to future possibilities: "I have lately been led, " he says, "to reflect a little ... on the artificial checks, but doubt greatly whether such would be advantageous to the world at large at present, however it may be in the distant future." In the first edition of the Descent of $\operatorname{Man}(1874),{ }^{2}$ he distinctly gives his adherence to the eugenic idea by his assertion that man might by selection do something for the moral and physical qualities of the race. It is a great

1 More Letters, I1., p. 43 and 50.

2 One Volume Edit. I894, p. 6 I 7 . 
thing that this Society should have had Francis Galton for its Honorary President. It entitles us to feel assured that in following the line of action marked out for ourselves we are on the right track, and that in the difficult pioneer work of helping the English public to realise the deadly need of eugenic reform we are following in Galton's steps. We are also so fortunate as to have received encouragement and help at the hands of some of the leaders in the science of heredity, Weismann, Yves Delage, Ray Lankester, the late Adam Sedgwick, Poulton, Bateson, and others.

Galton says somewhere ${ }^{1}$ that great men have long boyhoods. This was certainly true of him, though I should rather describe as youthful the delightful qualities that never faded out of his nature. It is, I believe, the correct thing to speak of the "golden dreams of youth," and if by this hackneyed phrase we mean a keenly imaginative outlook, a hopefulness with a certain dash about it, a generous courage-tinged with romance-then Francis Galton had undying youth. And this makes his seriously measured progress in eugenics all the more worthy of our admiration.

In one of the Macmillan articles he wrote: "Many plan for that which they can never live to see. At the hour of death they are still planning."

It was thus that Francis Galton died, and as year after year we meet together on February I6th, let us think of him and his plannings with affection and respect.

1 Macmillan's Magazine, xIr., p. 326. 


\section{III}

\section{THE MOVEMENTS OF PLANTS ${ }^{1}$}

It is sometimes asserted that the power of movement is a character distinguishing animals from plants. This statement arises to some extent from an obvious confusion of thought. Trees are stationary, they are rooted to one spot, but they are not therefore motionless. We think them so because our eyes are dull-a fault curable with the help of a microscope. And when we get into the land of magnification, where the little looks big and the slow looks quick, we see such evidence of movement that we wonder not to hear as well as see the stream of life that flows before our eyes.

In speaking of the cells of which plants are built, Huxley said that a plant is "an animal enclosed in a wooden box." It is this prisoner, the living protoplasm, that we may watch pacing round its prison walls. And we may see it stop as though frightened at our rough usage, and then, after a hesitating twitch or two, we see it recover and once more flow round the cell. Or we can watch under the microscope minute free-swimming plants rushing across the field of view, all one way, like a flock of little green sheep that we can drive to and fro with a ray of light for a sheep-dog.

1 Evening lecture delivered at the Glasgow meeting of the British Association, September I6, Igor. Reprinted with alterations, from Nature, November 14, 1901. 
But I am not going to deal with microscopic matters, but rather with things on a bigger scale which can be seen with the naked eye. I will begin by trying to show that very obvious movements are to be seen in every kitchen garden, or in every garret window, where a scarlet runner is grown for its red flowers' sake.

In a scarlet runner the shoot is not completely vertical, but bends over to one side. To record the movements of the plant a series of photographs may be taken vertically from above the plant, so that the end of the shoot shows like the hand of a watch against a sort of clock-face on which the points of the compass are marked. Such photographs show how the shoot swings round in its instinctive search for another stick to climb.

This well-known movement is performed by a co-ordinated series of curvatures, the exact nature of which need not trouble us now. Let us rather consider the less obvious power of co-ordination which enables a plant to grow upwards in a straight line. Think of a forest of pine trees, hundreds of thousands of them, all growing vertically up towards the sky. Here is a clear case of movement, for the leading shoots were once but a few inches from the ground, and now they are crawling along vertical lines 100 feet up in the air. It may be said that this is mere increase in size, not movement in the ordinary sense. But it may be made plain that the trees could not grow in this way had they not a power of curvature, to which the term movement cannot be refused.

As it is not easy to experiment on pine trees 
we may use a pot of mustard seedlings, which represents in miniature a forest of vertical stems. Now suppose the flower-pot upset and left lying on its side for a few hours : the seedlings will be found to have all recovered the vertical position, and they have done so by a bend which is just as much a case of movement as the flexure of a man's arm, though it is effected by a very different mechanism. Not everyone realises how rapid this movement is. Fig. 2 is from a diagram made in the ordinary course of class-work at Cambridge, and illustrates this point. A shoot of Valerian was placed horizontally at 2.17 , and a black line painted like a silhouette on a vertical sheet of glass to record its position at 2.30 ; similar lines were painted at intervals, forming a record of fairly rapid movement. If greater delicacy of observation had been practised, it would have been easy to show that the plant begins to curve up within a few minutes of being placed horizontally.

It is a remarkable fact that the plant should be stimulated, or stirred up, to a definite curvature by merely placing it horizontally. The curvature tends to bring the plant into the upright position, and when the whole stem has reached the vertical, the stimulus ceases to exist. It is as though the plant were in a condition of content when vertical, and of discontent in any other position, and as though the discontent expressed itself in curvature.

But the plant does not gain the vertical by a single continuous curvature; at first it overdoes the thing (see Fig. 2), and the end of the shoot may pass beyond the vertical by $20^{\circ}-30^{\circ}$. But this new 
position, inasmuch as it is not vertical, originates a new stimulus, and the new curvature which follows brings the shoot back towards the upright position. It may again overshoot the mark, but by repeated corrections it finally attains the normal upright posture.

It is this power of correcting the line of growth whenever it deviates from the upright that enables the pine tree to grow straight upwards. And this is what I meant when I said that its habit of growth depends on regulated curvature, to which no one can refuse the name of movement.

The pine and the seedling have, in fact, a wonderful kind of sensitiveness-a sensitiveness to

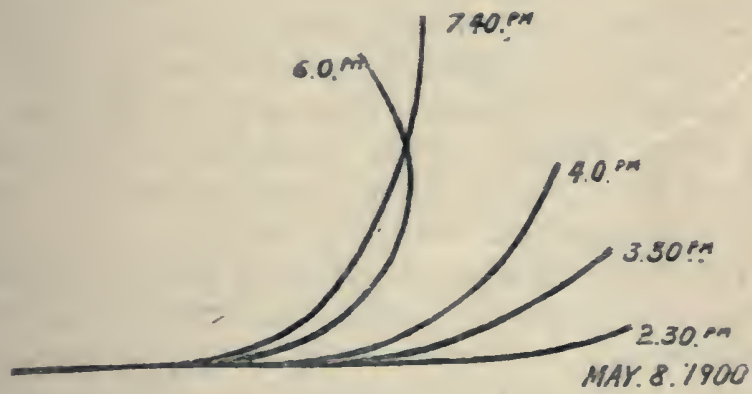

FIG. 2.-A Valerian stem curving geotropically.

the force of gravity. To those accustomed to think of Mimosa as the sensitive plant par excellence my words may sound strange. But the sensitiveness of Mimosa is crude by comparison with that of the seedling. A plant with a perception of the position of the centre of the earth and a power of growing 
along the line so perceived is a much greater miracle than a leaf that closes its leaflets when burnt or cut or shaken.

I shall show that certain parts of the plant have the special quality of the perception of gravitation, but we are at present ignorant of how the act of perception is effected. "We know something of the machinery of hearing or vision in animals, but in plants we can only guess that when a cell is placed horizontally a resulting change of pressure on the protoplasm produces that loss of equilibrium which is translated into curvature. It is, however, probable that Nĕmec and Haberlandt are right, and that the stimulus depends on the pressure of solid particles, e.g. starch-grains, on the protoplasm. ${ }^{1}$

The use of this gravitational sensitiveness is clear enough. It is to the pine tree what a plumbline is to the builder, for neither plant nor man can build high unless he builds straight. A man has a general perception of the verticalness of his body and of surrounding objects, but he does not trust to this sense in placing brick on brick to make a house. He uses a plumb-line which tells him through his eye the precise line along which he must pile his bricks. The tree has also to pile one over another the cells or chambers in which its protoplasmic body lives, and this too must be done along a vertical line; but the plant is guided by the sensitiveness to gravity of which I have spoken.

It must be clearly understood that gravity does not act directly on the growth of plants. It does

1 See their papers in the Deutsch Bot. Ges., 1900, and my summary in a paper read before the British Association, r905., 
not act as a magnet acts on iron, or to take a better example, it does not simply act as gravity acts on the plumb-line in which the string is kept in a vertical line by the weight. It might be supposed that in some occult way the stem was mechanically kept straight like the string, and this indeed was the view formerly held about such roots as grow straight down into the earth. But it is not so ; the thing is not explicable mechanically. Gravitation is nothing more than a sign-post or signal to the plant-a signal which the plant interprets in the way best suited to its success in the struggle for life, just as what we see or hear gives us signals of changes in the exterior world by which we regulate our conduct.

It may be said that this is hard to prove, and indeed, like other biological theories, it can only be shown to be true by its explaining a number of facts. It is interesting to try to explain the facts without the assumption in question. If gravity does not act indirectly as a signal it must act directly ; and we must find a reason why, in the case of the mustard seedling above referred to, the stem has grown up and the root down. There is absolutely nothing in their structure or manner of growth to help us to see why this difference of behaviour under identical conditions should exist. And if, instead of placing the mustard seedling in the dark we had grown it near the window, ${ }^{1}$ we should have come across another remarkable phenomenon, namely, that the stem grows towards,

${ }_{1}^{1}$ The root must of course be in a glass of water, and therefore exposed to light. 
the root away from, the light-and this is equally inexplicable on a mechanical basis.

But it may be urged that it is not fair to compare a root and a stem which are structurally unlike. Let us, therefore, keep to roots. When the root of a bean has grown vertically down into the soil for some distance it begins to bud forth into side roots. These are exactly like the primary root from which they spring; there is no difference in structure or in machinery of growth. Yet the secondary roots do not grow vertically down, but obliquely, or in some cases horizontally. There is one more striking fact about the roots of the bean. The secondary, like the primary roots, give off branches, and these-the tertiaries-behave differently from both the elder generations of roots. For instead of directing themselves vertically or horizontally, they simply treat the force of gravity with contempt and grow where fancy leads them. The point on which I wish to insist is, that it is impossible to explain on any theory of the direct action of gravity why the three orders of roots have three distinct modes of growth. They may remind us of three generations, grandfather, father, and son, all of one blood and yet behaving towards the universe in three distinct ways - a fact not unknown in human society.

On the other hand, it would not be difficult to show that the behaviour of the three orders of roots is well suited to the plant's needs, and therefore we can understand how the power of reacting in three different ways to the same signal has been evolved. The main root takes the shortest course 
to the deeper layers of earth ; the four or five ranks of secondary roots divide the world between them and push forth all round, keeping slightly below the horizontal; the tertiaries take it for granted that their predecessors have done the usual thing, and that they can satisfactorily occupy the spaces left among their elders by random growth. The fact that the tertiary roots have no specialised sensitiveness of gravitation shows that their unregulated growth is good enough for the necessities of the case. For among organised beings necessity is the mother of development, and what their brethren of second rank have developed they too could assuredly have gained. To this point of view I shall return, but first I should like to give a few more instances of actions carried out in response to the signal of gravity; and these examples shall be from stem-structures.

The ripe flower-heads of a clover ( $T$. subterraneum) bury themselves in the ground, thus effectually sowing their own seeds, and they are guided to the ground by their unusual capacity of curving down and directing themselves like a primary root towards the centre of the earth.

Other flower-stalks are guided by gravitation for quite different purposes. Take, for instance, a common narcissus. In the young condition there is a straight shaft ending in a pointed flowerbud ; but as the flower opens the stalk bends close to the top and brings the flower-tube into a roughly horizontal position, where it shows off its brightly coloured crown to the insects that visit it. The flowers are guided to the right position by the 
gravitational sense, and they increase or diminish the angular bend in their stalk till the right position is attained, as shown in Fig. 3.

All these cases of plants executing certain useful curvatures, which occur when the plant is displaced as regards the vertical, and cease when the habitual, relation is reached, all these, I say, seem to me only explicable on the theory that gravitation does not act as a mechanical influence, but as a signal which the plant may neglect entirely, or, if it notices, may interpret in any way; that is, it may grow along the indicated line in either direction or across it at any angle. It may be said that this is no explanation at all, that it only amounts to saying that the plant can do as it chooses. I have no objection to this, if the meaning of the word 'choice' be defined.

I am now going to deal with the subject of movement from a somewhat different point of view, namely, with the object of showing that it is possible to discover the part of the plant which reads the signal: and this is not necessarily the part that executes the correlated movement. In the reflex movement of an animal (for instance, a cough produced by a crumb going the wrong way), we distinguish the irritation of the throat and the violent action of the muscles of the chest and abdomen; and further, the nervous machinery by which the stimulus is reflected or switched on, by way of the central nervous system, from the throat to the muscles concerned in coughing. In the plant, too, if we are to compare its movements to the reflexes of animals (as has been done by Czapek), we must distinguish a region of percipience, another of motility, and the 
transmission of an influence from the percipient to the motor region.

Transmission of a stimulus has long been known in Mimosa, but, in the far more important curvatures which we are now considering, it was not known to

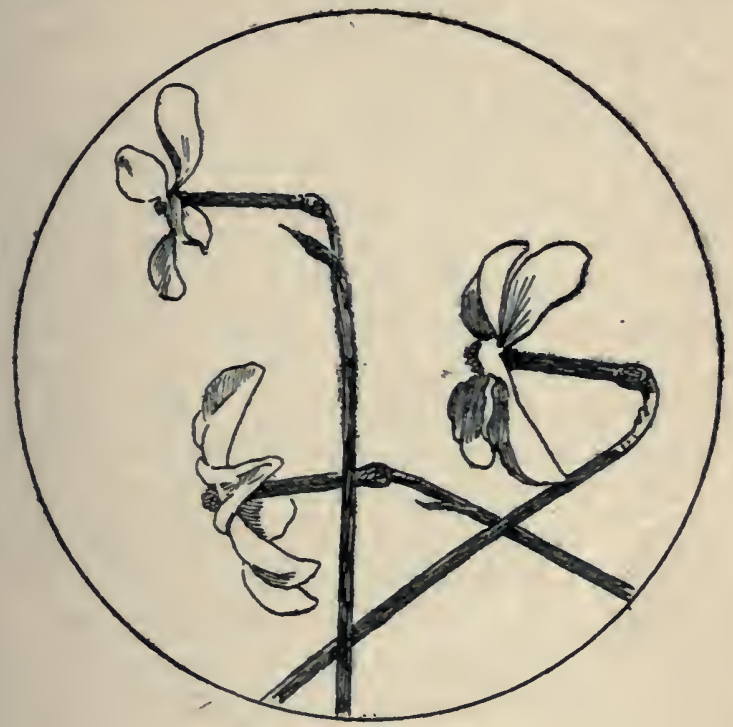

FIG. 3.-Narcissus flowers.

exist before the publication of the Power of Movement in Plants. There is an experiment of Rothert's ${ }^{1}$ which we make in class-work at Cambridge, and which only differs from my father's classical experiment in the fact that a much more perfectly adapted plant is employed. The plant in question is a grass, Setaria, which has a remark-

1 Cohn's Beitrage, 1894 . 
able form of seedling. When the grain germinates it does not send up a simple cylindrical sprout like an oat, but a delicate stem terminating in a pointed swollen part which looks like a little spear-head. When a group of Setarias is illuminated from one side they bend strongly over, with their spearheads all pointing straight at the light. The spearheads do not bend; the whole movement is carried out by the stalk on which the head is supported. And what is remarkable is, that the spear-head and not the stalk perceives the light. This is easily proved by covering the heads of a few Setarias with opaque caps. For the result is that the blindfolded seedlings remain vertical while their companions are pointing to the light. Thus the part which bends is unaffected by illumination, and the part which is affected does not bend. The spear-head is the percipient organ, the shaft or stalk is the motor region, and from head to shaft an influence has clearly been transmitted.

My father and I made an attempt to prove the same thing for the gravitation-sense of roots, that is, to prove that the tip of the root is the region in which the force of gravity is perceived by the plant. Our method of proof does not hold good, but our conclusions are true after all. When gravitation is the stimulus, the experiment is much more difficult than when light is in question, because now that fairy godmothers are extinct we must not hope for a substance opaque to gravitation, a substance with which we might shelter the root-tips from the force of gravity as the tips of the Setaria seedlings were sheltered from light. 
The plan adopted by us was simply to cut off the extreme tip of the roots, and fortunately (or unfortunately) the result was just what was expected-the tipless roots had lost the sense of gravitation, and were unable to curve downwards towards the centre of the earth. It was natural to believe that the tipless roots failed to bend because their sense-organs-their percipient parts-had been removed. As a matter of fact they had been removed, but it was fairly objected that the operation of removing the delicate tissues at the tip of the root is a severe one, and that the roots which refused to grow downwards were suffering from shock, and not from the absence of their senseorgans.

The subsequent history of the inquiry is an instance of the unwisdom of prophesying unless you know. In 1894 an able summary of the question was published in a German journal, in which the impossibility of solving the problem of the gravitational sensitiveness of the root-tip was dwelt on, and immediately afterwards Section $\mathrm{K}$ of the British Association had the satisfaction of hearing Pfeffer read a brilliant paper giving the long-hoped-for proof that the tip of the root is a sense-organ for gravitation. ${ }^{1}$

Like many other experiments, it depends on a deception or trick played on the plant. The root is forced to grow into a minute glass tube closed at one end and sharply bent in the middle, resembling a little glass boot; the extreme tip being thus

1 Pfeffer, in the Annals of Botany, September 1894. Further details in Czapek's paper in Pringsheim's Jahrb., I895. 
kept at right angles to the main body of the root. If the theory we are testing is the right one, a root with its motor region horizontal and its tip vertical ought to continue to grow horizontally, because the tip being vertical is not stimulated by gravity ; it is in a quiescent, or, as it were, a satisfied condition, and no bending influence is being sent to the motor region. And this is what Pfeffer and Czapek found. On the other hand, if the main body of the root points vertically down while the sensitive tip is horizontal, a curvature results, because as long as the tip is horizontal it is stimulated, and the stimulus is transmitted to the motor region.

This experiment proves not only that the tip of the root is the sense-organ for gravity, but also that the motile part is not directly sensitive; in other words, that gravitation is perceived exclusively in the tip of the root. Since the publication of Pfeffer's and Czapek's papers I have been lucky enough to hit on another way of investigating percipient organs for gravitation, ${ }^{1}$ and I am not without hopes that botanists may become in this question as fertile as Cyrano with his seven ways of flying to the moon.

There is a certain kind of inverted action familiarly known as the tail wagging the dog, and it is on this principle of inversion that my experiment is designed. Inversion may in some cases be practised without altering the final result. For instance, it does not much matter whether the thread goes to the eye (the rational masculine

F. Darwin, Annals of Botany, December 1899. 
plan) or vice versa, as in the feminine way of threading a needle. In other cases you create what is practically a new machine by inversion, as in a certain apparatus in which the hand of a clock stops still while the clock itself rotates. The effect is still more striking with my plants, for the inversion practised on them entirely changes the character of their movement.

The result may be shown with the seedling Setarias of which I have spoken, or with Sorghum, as in Fig. 4. If one of these is supported by its seed with its stem projecting freely in the horizontal plane, the gravitation stimulus makes it bend upwards until the tip is vertical, when the stimulus ceases to act and the curvature comes to an end. If the conditions are reversed, if the seedling is supported in a horizontal position by its tip, while the seed projects freely, the result is at first the same, though finally it comes to be strikingly different. The basal end of the seedling is carried upwards by the curvature of the stem; but according to the theory we are testing, the tip of the seedling is the only part of the plant which feels the gravitational stimulus, and the tip of the seedling remains horizontal in spite of the curvature of the stem. Therefore the tip of the seedling is not freed from stimulation as it was in the first case, where the curvature brought the tip into the vertical position. The horizontal tip therefore continues to send commands to the stem to go on curving, in a way I can best explain if I am allowed to make the plant express its sensations in words. The tip says to the stem, "I am horizontal, therefore 
you must bend upwards" ; and when this order has been obeyed the tip says, "It is of no use, I am still horizontal-go on bending." The result is that the stem curls up into a spiral like a corkscrew or a French horn, as shown in Fig. 4.
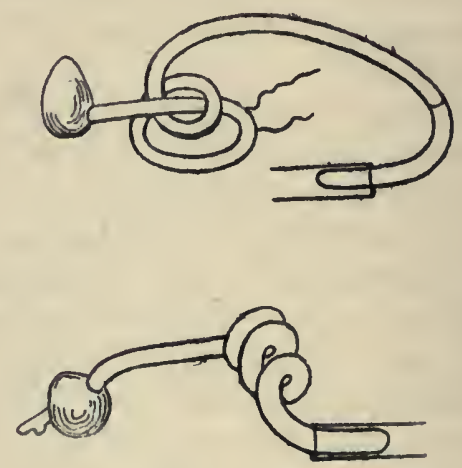

FIG. 4.-Seedling Sorghums supported by their tips in horizontal glass tubes. (From the Annals of Botany, December 1899.)

These unfortunate plants are in the position of a convict on the treadmill ; their movements are, from their own point of view, absolutely ineffectual and meaningless. The results are, however, of some importance from our point of view, since they give clear support to the theory which I have now attempted to place before you, namely, that the percipient region is at the tip of the Setaria seedling, and that by what corresponds to a reflex action, the stimulus perceived by the tip is transmitted to the motor region.

I should like to add a few words on the question ow far the movement of plants can be placed under 
the general laws deducible from the movements of animals. Unfortunately, as soon as we attack this question we are liable to enter regions where for the ignorant there are many pitfalls. We are, in fact, face to face with the question whether in plants there is anything in which we may recognise the faint beginnings of consciousness, whether plants have the rudiments of desire or of memory, or other qualities generally described as mental.

If we take the wide view of memory which has been set forth by S. Butler ${ }^{1}$ and by Hering, we shall be forced to believe that plants, like all other living things, have a kind of memory. For these writers make memory cover the whole phenomena of life. Inheritance with them is a form of memory, or memory a kind of inheritance. A plant or an animal grows into the form inherited from its ancestors by passing through a series of changes, each change being linked to the preceding stage as the notes of a tune are linked together in the nervous system of one who plays the piano. Or we may compare the development of an animal or plant to the firing of a train of gunpowder, which completes itself by a series of explosions, each leading to a new one. To use the language I have been employing, each stage in development acts as a signal to the next.

In the same way the characteristic element in what is done by memory, or by that "unconscious memory"' known as habit, is the association of a

${ }^{1}$ Life and Hablt, 1878 .

2 Butler's term. 
chain of thoughts or actions each calling forth the next.

What I wish to insist on is, that the process I have called action-by-signal is of the same type as action-by-association, and therefore allied to habit and memory. The plants alive to-day are the successful ones who have inherited from successful ancestors the power of curving in certain ways, when, by accidental deviations from their normal attitude, some change of pressure is produced in their protoplasm. With the pianist the playing of A has become tied to, entangled or associated with, the playing of $B$, so that the striking of note $A$ has grown to be a signal to the muscles to strike B. Similarly in the plant, the act of bending has become tied to, entangled or associated with, that change in the protoplasm due to the altered position. There is no mechanical necessity that $B$ should follow $\dot{A}$ in the tune ; the sequence is owing to the path built by habit in the man's brain. And this is equally true of the plant, in which an hereditary habit has been built up in a brain-like roottip.

The capacities of plants of which I have spoken have been compared to instincts, and if I prefer to call them reflexes it is because instinct is generally applied to actions with something of an undoubted mental basis. I do not necessarily wish it to be inferred that there can be nothing in plants which may possibly be construed as the germ of consciousness-nothing psychic, to use a convenient term ; but it is clearly our duty to explain the facts, if possible, without assuming a psychological resemb- 
lance between plants and human beings, lest we go astray into anthropomorphism or sentimentality, and sin against the law of parsimony, which forbids us to assume the action of higher causes when lower will suffice.

The problem is clearly one for treatment by evolutionary method-for instance, by applying the principle of continuity. ${ }^{1}$ Man is developed from an ovum, and since man has consciousness it is allowable to suppose that the speck of protoplasm from which he develops has a quality which can grow into consciousness, and, by analogy, that other protoplasmic bodies, for instance those found in plants, have at least the ghosts of similar qualities. But the principle of continuity may be used the other way up; it may be argued that if a lump of protoplasm can perform the essential functions of a living thing, to all appearances without consciousness, the supposed value of consciousness in Man is an illusion. This is the doctrine of animal automatism so brilliantly treated by Huxley. ${ }^{2} \mathrm{He}$ is chiefly concerned with the value of consciousness to an organism-a question into which I cannot enter. What concerns us now is, that however we use the doctrine of continuity, it gives support to belief in a psychic element in plants. All I contend for at the moment is, that there is nothing unscientific in classing animals and plants together from a psychological standpoint. For this contention I may quote a well-known psychologist, Dr. James Ward, ${ }^{3}$

1 See James Ward, Naturalism and Agnosticism, i. 283

Sctence and Culture, Collected Essays, i.

Loc. cit. p. 288. 
who concludes that mind "is always implicated in life." $\mathrm{He}$ remarks, too (ibid. p. 287): "It would be hardly going too far to say that Aristotle's conception of a plant-soul ... is tenable even to-day, at least as tenable as any such notion can be at a time when souls are out of fashion."

This is a path of inquiry I am quite incapable of pursuing. It would be safer for me to rest contented with asserting that plants are vegetable automata, as some philosophers are content to make an automaton of Man. But I am not satisfied with this resting-place. And I hope that other biologists will not be satisfied with a point of view in which consciousness is no more than a bye-product of automatic action, and that they will in time gain a definite conception of the value of consciousness in the economy of living organisms. Nor can I doubt that the facts discussed in these pages must contribute to the foundation of this wider psychological outlook. 


\section{IV}

\section{A LANE IN THE COTSWOLDS}

Early in May I walked up from the valley to the extreme rim of the Cotswolds, just above our house. The lower country is all pasture, where we can wander at will, and delight in the many beautiful trees: the fresh green elms, the vernal yellow of the oak (which lingers in varying degrees behind some of its companions, but does not deserve Tolstoy's epithet ' maussade'), and the grey anatomy of the timid ash, whose black buds are still getting up their courage. We do not owe the trees in the meadows to landowners with a taste for natural beauty, but to the cattle that must have shade.

The buttercups are beginning their golden show, and there is not much else to decorate the fields, except daisies and the cheerful dandelions. These last are still growing obliquely, and not yet staring boldly up at the sky, as in later life. There is also an occasional patch of bugle-sturdy little blue sentinels, and a few purple orchids. In the upper meadows where the wind is cold the daisies bend their stalk and lay their heads on the ground (as they do at night), and their little noses look red like poor Marian's in Shakespeare's winter song. In 
the daisy it is the pink-tipped petals ${ }^{1}$ huddling together that make this chilly symbol a contrast to the happy star that sunshine shows.

Near the top of the hill is a bare pasture covered with cowslips, all pointing their pretty heads one way. At first it seemed that they were simply yielding to the fresh wind, but on picking them it was made clear that they bent their stalks wilfully, not on compulsion. On the whole it seemed that they were nodding towards the brighter light, but I could not perceive that the quarter to which they turned had any advantage in luminosity.

Close to the top of the hill is a little wood of nut-trees, and I looked down into it over the hedge with a shock of pleasure at the chequer-work of white and blue, a conspiracy of wild garlick and blue-bells. In this land I have not seen the blue haze covering acres of cleared woodland such as we have in Kent. But this colour-dance of the two plants is beautiful in its own way. Now we have reached the rim of the valley, and look over into a new country, with many red patches of ploughed land, and sheep in the treeless fields instead of cattle. Here the skylark sings, who is something of a stranger to us dwellers in the valley. The same is true of the yellow-hammer, whose hot and dusty voice is less familiar there. To one inland bred the seagulls feeding in the ploughed lands are a delight. They seem an echo from the salt sea, or a variation (in a musical sense) on the far away silver

Strictly speaking-florets. 
strip which is the Severn shining down to the Bristol Channel.

We now come to a little wandering road, called for reasons unknown to me Seven Leases Lane, and after a time end our wanderings at a point whence we can look down on misty Gloucester and its cathedral ; and this is a historic spot if the rumour is to be trusted, that from here King Charles watched the siege. The lane is pleasant with its plashed hedges beset with traveller's joy (clematis) and bryony. Clematis likes to climb up trees, but it seems quite happy ramping over the hedges. It is now in its freshest youth, and the careless way in which the young stems toss themselves hither and thither gives an impression of endless living things dancing with complete abandon on the hedge as on an airy floor. The traveller's joy climbs by seizing hold of the branches of plants more solid than itself. It grips them with its leaf-stalks, which serve as tendrils and support the weakling stem aloft in the clear air. But as yet they have hardly begun to fix themselves; though some I saw which had caught each other, giving themselves a gay aspect by seeming to dance hand in hand.

The white bryony is there also, and its tendrils have fastened on to the hazel, beech and dog-wood, which make up the mass of the hedge. Their tendrils are but delicate ropes, and when they have seized a twig they would break away in the first fresh breeze. But this is prevented by the fact that the tendrils contract into spiral springs, and by the give-and-take of its elastic coils the cable 
becomes almost unbreakable and the ship rides out the stiffest gale. ${ }^{1}$

Two other types of climbing plants are common in our lane, which have neither the grasping leafstalks of clematis nor the delicate tendrils of white bryony. Black bryony is a twining plant, and can travel spirally up the hazel stems, just as a hop ascends its pole. But here in our lane there is but little to climb up, and its livid pink stems, often twisted with one or more brother-strands, lie along the hedge or sway in the air like discontented snakes. Just now they hardly show any leaves, but later in the spring they will have finely polished ones, and later still bunches of red berries, which do not seem to be popular with birds, and hang on their branches till winter comes. Another type of climber which shows itself early is the goose-grass. ${ }^{2}$ This is a humble personage, probably looked down on by the superior climbers above described, as able neither to swarm spirally nor to ascend by the aid of tendrils or other gripping apparatus. The goose-grass depends on the possession of delicate little hooks covering stem and leaves. These can be perceived by stroking the plant from the base upwards, but not in the other direction. The hooks being directed downwards do not hinder the upward push of the growing plant, but they prevent it from slipping downwards. If one disentangles a goose-grass from its position it will fall weakly over and lie along the ground. In its

1C. Darwin. Climbing Plants.

¿Galium aparine. 


\section{A LANE IN THE COTSWOLDS}

simple way it gains the object aspired to by all climbers, namely the possession of a satisfactory position in the world without going to the expense of building a stem stiff enough to stand alone. To children goose-grass is valuable as the ideal material for the making of sham birds' nests, since the hooked prickles hold the stems in position and make the art of nest-building a singularly easy one.

The great revolution that breaks out in the spring, when the store-houses of the plant pour nutriment into the numberless awakening buds is a miracle annually repeated in the endless procession of life. We know something of the mechanism by which mobilisation is effected. We know for instance that the starch-grains guarded by the dormant plant during the idle days of winter are liquified, or rather, that the starch is converted into sugar, and being soluble in water can flow from the magazines of the plant to where growth, implying the creation of millions of newly born cells, demands material. We are gradually learning to understand something of that seething cauldron of life which we can dimly watch in living things. The ferment diastase is one of the tools with which plants perform their miracles of chemical activity. This diastase and its brotherferments have qualities resembling those of living creatures. They may, like seeds, be dried and kept in a bottle until they are awakened by giving them water. Perhaps this is talking in a circle, and that ferments only resemble living things because organisms contain so many of these mysterious bodies. I like to fancy that there is 
something more than this, and that a ferment is an automaton which the plant compels to labour for it-a Frankenstein monster having semi-living qualities, being no more than a parody of life. But I am getting beyond the questions that are in tune with a spring day. 


\section{V \\ JANE AUSTEN}

The most obvious characteristic of English country life as described by Jane Austen, is a quietness such as even the elder generation now living have not experienced. A quietness which many would call dull and some few peaceful. It is, indeed, hard to believe that life was once so placid, so stay-at-home, so domestic, so devoid, not merely of excitement, but of any change whatever.

The life of Emma Woodhouse (to take a single instance) has all the characteristics of this deep repose. At Hartfield there was certainly no changing "from the blue chamber to the green," a revolution which would have made Mr. Woodhouse seriously unwell.

Emma never seems to leave home, she had not seen the sea, nor indeed had she (before a memorable occasion) explored Box Hill, a few miles away, although her father kept a carriage and a pair of horses. Nor is there any evidence of her going to London, a distance of sixteen miles. She did not engage in good works; there were no committees or meetings except those held at the 'Crown' at which Mr. Knightly and Mrs. Elton's cara sposo were the leaders, and where no ladies were admitted. 
In comparison with the hurried unsheltered life of the modern girl, Emma seems a princess shut in a tower of brass or an enchanted garden. And although in the course of the story she escapes this particular tower, it is only to fall into the castle of Mr. Knightly, who (with his squire William Larkins) plays the part of knight errant.

And Emma was not dull, but full of happy animation, and her quiet life encouraged the growth of an educated, or at least a cultivated, condition which re-appears in the other novels. This placid life is all the more striking in contrast to the great contemporary struggle of the Napoleonic wars, hardly a sound of which reaches Miss Austen's readers, although in Persuasion we do hear something of Captain Wentworth's prize money. George Eliot knew the flavour of this quietude, and reproduces it in the introduction to Felix Holt. But even in these pre-reform days the quiet is beginning to be broken; the stage-coachman is beginning to dread the railway train, and looks on Mr. Huskisson's death as a proof of God's anger against Stephenson. Again, in Middlemarch we see the country stirring in its sleep, and poor Dorothea suffering in the process of awakening. There is nothing of this in Miss Austen; it is true that the Miss Bennets sometimes experienced the blankness of female existence, but they could imagine nothing blanker than the departure of the militia from Meryton.

Jane Austen's books have something of the quiet atmosphere of Cowper's Letters. Mr. Austen Leigh in his Memoir speaks of her love for the 
writings of Cowper and of Crabbe (the latter indeed she proposed to herself to marry). We know that Marianne Dashwood (that type of sensibility) was very far from finding Cowper too quiet. For when Edward Ferrars failed to read him aloud with spirit, Marianne remarks, "Nay, mamma, if he is not to be animated by Cowper!"

Bagehot ${ }^{1}$ in his article on the Letters of Cowper unconsciously describes the life at Hartfield or Mansfield Park. Of Cowper he writes: "Detail was his forte and quietness his element. Accordingly his delicate humour plays over perhaps a million letters mostly descriptive of events which no one else would have thought worth narrating, and yet which, when narrated, show to us, and will show to persons to whom it will be yet more strange, the familiar, placid, easy, ruminating, provincial existence of our great grandfathers."

The domestic and intimate parts of life are the most lastingly happy, and thus it is that an imaginary existence, which in some moods seems to be unbearably humdrum, harmonises with the best parts of our own life. The quiet winds that blow through Miss Austen's imagined land cannot turn windmills or overset tall trees, but they can set going those tunelike chains of simple experiences written on our memories by the quiet and happy parts of life.

Imaginative writing is often compared to painting, and Miss Austen has spoken" of "the little bit (two inches wide) of ivory on which I work

${ }^{1}$ Literary Studies, Vol. I., p. 303.

${ }^{2}$ Momoir, p. 155. 
with so fine a brush, as produces little effect after much labour." But this gives a false impression, suggesting a niggling character from which her work is free. What strikes one is rather how much she conveys by touches which seem trifling until we realise the triumph of the result. The effect is not a miniature, as the author suspects, but something essentially broad in spite of its detail, like a picture by Jan Steen.

To discuss why Jane Austen's humour is admirable, or how she reaches such perfection in the drawing of character, seems to me as hopeless as to ask by what means Bach or Beethoven wrote such divinely beautiful tunes. Her powers are rendered even more admirable by the fact ${ }^{1}$ that she did not draw portraits, so that no one could say $A$ is Mr. Collins and $B$ is Mrs. Palmer.

I think it is true, but not easily explained, that the simplest people in her books give us most pleasure. Why is Admiral Croft so delightful, and why do we read again and again the speech about his wife, who suffered from sharing the exercise prescribed for her husband's gout? "She, poor soul, is tied by the leg with a blister on one of her heels as big as a three-shilling piece." Why do we delight in Mr. Woodhouse's perambulation among his guests, and his words to Jane Fairfax, "My dear, did you change your stockings ?" In this respect we have advanced beyond the Quarterly reviewer of $1815,^{2}$ who says: "The faults of these works arise 
from the minute detail which the author's plan comprehends. Characters of folly or simplicity, such as those of old Woodhouse and Miss Bates, are ridiculous when first presented, but if too often brought forward, or too long dwelt on, their prosing is apt to become as tiresome in fiction as in real society." If ever a reviewer "damned himself to everlasting fame," surely this writer did so ; but, indeed, we need not have quoted so much, since (in the words of Corporal Trim) "he is damned already" for leaving out the 'Mr.' before the name Woodhouse.

But six years later (1821) another Quarterly reviewer (said to be Archbishop Whately) reversed the above unfortunate judgment by singling out the drawing of Miss Austen's fools as shining examples of her skill.

Jane Austen must surely be the most re-read author of the last hundred years. Lord Holland is said to have read her books when he had the gout, and in that case he must have experienced what smaller people have suffered during less picturesque complaints, viz., from not being able to determine which of her books they have most nearly forgotten. In this frame of mind one longs for a new Miss Austen more than for a new symphony of Beethoven, or a play of Shakespeare, and much more than for the lost books of Livy, which, indeed, I, for one, do not desire at all.

The power of endlessly re-reading the novels of Miss Austen is the only advantage conferred by a bad memory. I do not imagine that Macaulay, greatly as he admired her, could have endured to 
read her as often as I have. Nor am I willing to allow that this is intellectual idleness, for her works like those of Nature, always yield something new to the faithful student.

And she, like Nature, has the power of creating in her devotees a minute interest which I rarely experience in other writers. It does not seem to Austenites a foolish thing to inquire what was Mr. Woodhouse's Christian name, a problem only soluble by remembering that he thought it "very pretty" of poor Isabella to call her eldest little boy Henry, and by implication proving that the child, who should have been christened John after his father, was named after his grandfather. And I am proud to remember that when the problem of Mr. Woodhouse's name was propounded to my mother, she solved it at once, and as though it were a question too simple to be asked. Nor does it seem to us trivial that the word given by Frank Churchill to Jane during the "word-game" at Hartfield was 'Pardon.' This was traditionally known in the author's family, indeed Mr. Austen Leigh ${ }^{1}$ says that she was always ready to reveal such valuable facts as that Mrs. Norris' "considerable sum" given as a present to William in Mansfield Park was one pound; that Miss Steele never caught the Doctor, and that Mary Bennet married an unfortunate clerk of her uncle Philip's. These revelations lend an air of history to her romance, they give the exciting quality of treasuretrove to the secrets she shares with us. "And 
here," as children's books say, "a very pretty game may be played by each child saying" what question he would put to the ghost of Jane Austen. For myself I believe I should ask, "Would Fanny Price really have married Crawford if he had not eloped with Miss Bertram? If in the words of Captain Price there had not been "the devil to pay" in Wimpole Street. Then, too, I should have liked some eugenic information about Elizabeth's (Mrs. Darcy's) children. Because if there was reversion to the type of Lydia it would have been serious. One can fancy Elizabeth retorting that if he said another word about the Lydia type she would pray for an infant possessing all the qualities of Lady Catherine de Burgh, a gift well within the powers of the gods who rule heredity.

I doubt whether Jane Austen consciously painted the results of heredity; rather, I suppose that her memory working instinctively, made, for instance, the Bennet family consist of types recalling the father or mother. She could hardly have known of the questionable theory that the eldest child is commonly inferior to the second, and nevertheless she makes Jane Bennet inferior in capacity to Elizabeth, although so greatly superior to the younger children of Mrs. Bennet's type.

There are other cases of heredity among her characters; for instance, in Persuasion, the snobbery and selfishness of Miss Elliott clearly reproduces her father, while Anne, as we know from Lady Russell, was a true child of her mother. I like to fancy that the querulousness and weakness of Mary (Mrs. Charles) was a perverted gentleness coming from 
her mother, while her vulgarity came from Sir Walter. Then again, Emma had none of $\mathrm{Mr}$. Woodhouse's qualities, and we must suppose her to be a repetition of her mother. Unless, indeed, her general kindliness came from her father, and possibly also the stupidity which wrecked her matrimonial agency. We must, I think, believe that Mrs. Woodhouse had been a managing woman, who probably insisted on Mr. Woodhouse marrying her ; thus her instinct for matrimonial scheming was confined (we may fancy) to her own interests. It is too fanciful to suggest that Mrs. Woodhouse had a tinge of hardness in her which came out in Emma's celebrated rudeness to Miss Bates. At any rate, it is certain that it was not a heritage from her father. I knew a lady who could never forgive this slip of poor Emma. And the vividness of this feeling was not a symptom of that want of literary sense which makes the gallery hiss the villain on the stage, but must be taken as a proof of the vitality of the character. Isabella Woodhouse is obviously of her father's type, with hardly a mental feature to remind us of Emma.

In the Bertram family the inheritance is not very clear; the Miss Bertrams seem to show the hard narrowness of Mrs. Norris, and none of the sheep-like good nature and futility of Lady Bertram. I suspect that in Mrs. Norris, hardness and business tendency were an inheritance from her uncle, the Huntingdon solicitor, for we know that he made the harsh and commercial statement that his niece was at least $£ 3000$ short of any equitable claim to the hand of Sir Thomas. We do not know any- 


\section{JANE AUSTEN}

thing of the parents of Lady Bertram, but we may suspect that her Ladyship inherited from her mother the soft and cushiony character of which she is a great example. Mrs. Price, with her small income and large family, was unfortunately of the same easy and futile temper. Edward Bertram is obviously his father the Baronet over again, with all his kindness and extreme respectability, while what will ultimately grow into Sir Thomas' pomposity is like the delicate tissues of the sucking pig in Charles Lamb's essay, not to be described by the gross terms applicable to the adult, "Oh, call it not fat ! but an indefinable sweetness growing up to it," etc. The elder brother, Tom, who began life as a cheerful, irresponsible person, falls under the family curse in consequence of a mysterious fever, so that he doubtless inherited the fatal tendency from Sir Thomas, together with a certain insonciance and want of heart, which one can imagine to be forms of Lady Bertram's emptiness and Mrs. Norris's hardness.

This is a subject on which a Mendelian inquirer might endlessly speculate, but the characters in fiction being even less susceptible to experiment than our living friends and acquaintance, the interest of the matter is soon exhausted.

It is to be regretted that Miss Austen did not allow the characters of one novel to appear in the next. It is true that this would have upset plots in an absurd way, but I should like to know what would have happened if, when Henry Tilney had made up his mind that he was in love with Catherine, Elizabeth Bennet had appeared? He would 
surely have repented of his entanglement with Catherine. There is, however, this to be said, that I strongly suspect Elizabeth of being his first cousin. She is so like him that she might have failed to please him, or he may have known her from a little girl and looked on her as a sister. Or the marriages of cousins may have been as impossible among the Tilneys as in the Royal Family of Crim Tartary, where Bulbo's beautiful Circassian cousin simply had to be allowed to die of love for him.

There are many possibilities in the combination of characters now separated by inexorable paper and ink. One can imagine a meeting at Bath between General Tilney and Sir Walter Elliott; they would clearly sympathise, and unless the General has injured his complexion by incautious zeal on active service, which seems unlikely, Sir Walter would have had "no objection to being seen with him anywhere"; he might even have walked arm-in-arm with him as he did with Colonel Wallis, who "was a fine military figure, though sandy haired." Again, Mr. Collins would have been charmed with Mr. Dashwood in Sense and Sensibility, for although the two characters are not quite similarly compounded of snobbery and folly, yet there is a common substratum of meanness that must have served as a bond.

It would be interesting to treat the whole of Miss Austen's characters as the flora of a given land is dealt with, to divide them into genera and species, and to provide an analytical key. Take, for instance, the young men: these would corres- 


\section{JANE AUSTEN}

pond to a Natural Order, say the Ranunculaceae, and may be divided, as the following table shows,

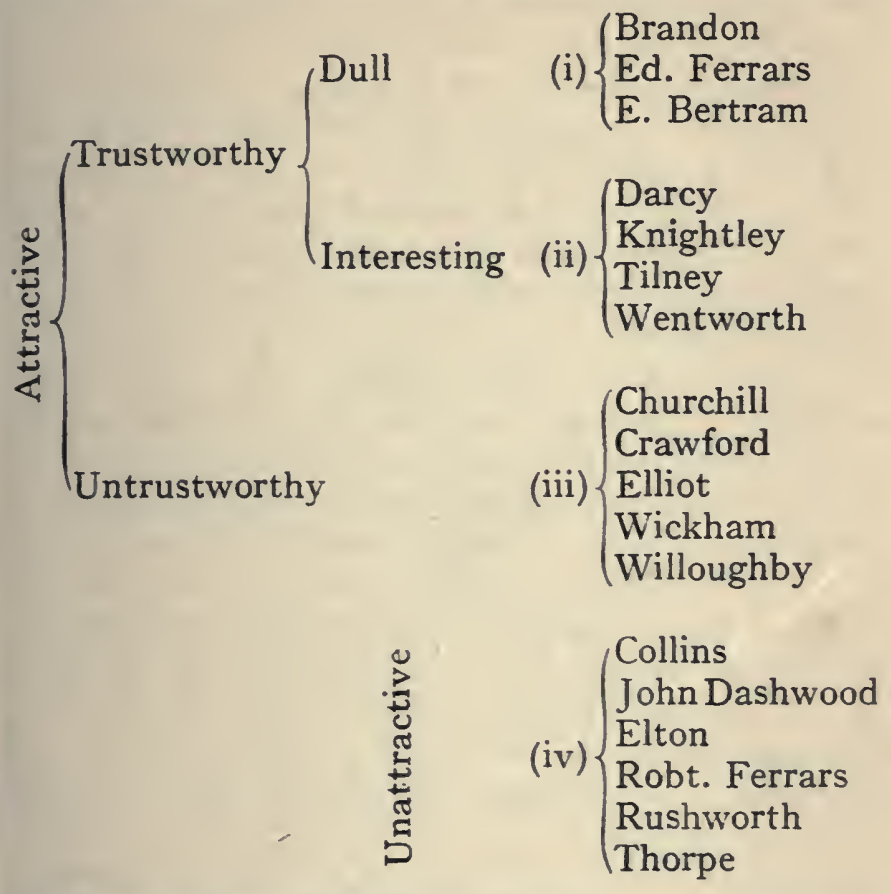

into two groups, Attractive and Unattractive, and these are subdivided again into four groups which correspond to genera. No. 1, which we should call Brandonia, possesses the three species Brandonia brandoni, ferrarsi, and bertrami, and so on with the rest.

Brandon, Dashwood, Ferrars, R. Ferrars, Willoughby are in Sense and Sensibility; E. Bertram, Crawford, Rushworth in Mansfield Park ; 
Mr. Collins, Darcy, Wickham in Pride and Prejudice; Tilney and Thorpe in Northanger Abbey; Mr. Elton, F. Churchill and Knightley in Emma; Wentworth and Mr. Elliot in Persuasion.

Then of course we should need descriptions to distinguish the species, thus in genus (ii) Darcy would be known by pride, Knightley by calm sense, Tilney by light-hearted cheerfulness, while Wentworth would be easily recognised by his subdull character. Naturalists would dispute whether $\mathrm{Mr}$. Elton should be in the same genus as Wickham, or in the quite distinct genus (iv); or again, whether F. Churchill should not beplaced with Darcy and Knightley. In thesame way Captain Wentworth might perhaps be placed in the dull group with Brandon, Edward Ferrars and Edward Bertram.

I have not attempted to include in the system all the young men who occur in the novels. I leave the completion to those who can devote a life-time to the subject, and who are possessed of the necessary discrimination and patience to marshall and arrange the whole flora of Miss Austen's world.

In connexion with this subject I have found it interesting to read for the first time quite recently Miss Austen's unfinished novels, Lady Susan and The Watsons. It is easy to classify some of the characters-thus Mrs. Robert Watson is obviously Mrs. Elton, as, indeed, Mr. Austen Leigh points out in his Memoir.

In the following scene the character addressed as Jane is Mrs. Robert Watson, who has come to stay at the house of Mr. Watson, her father-in-law. 
Elizabeth is the eldest of the Watson girls, and keeps house for her father. "I hope you will find things tolerably comfortable, Jane," said Elizabeth, as she opened the door of the spare bed-chamber. ${ }^{1}$

"My good creature," replied Jane, "use no ceremony with me, I entreat you. I am one of those who always take things as they find them. I hope I can put up with a small apartment for two or three nights without making a piece of work. I always wish to be treated quite en famille when I come to see you. And now I do hope you have not been getting a great dinner for us. Remember we never eat suppers." And then: "Mrs. Robert, exactly as smart as she had been at her own party, came in with apologies for her dress. 'I would not make you wait,' said she, 'so I put on the first thing I met with. I am afraid I am a sad figure. My dear Mr. W. (addressing her husband) you have not put any fresh powder in your hair."

This is certainly Mrs. Elton's double, and the resemblance extends to calling her husband $\mathrm{Mr}$. W. It gives one a certain shock of surprise to find an old friend masquerading as a new acquaintance, nor is she the only example in the book. I think the following speech of Mr. Tom Musgrave will recall a well-known character.

"Oh, me," said Tom, "whatever you decide on will be a favourite with me. I have had some pleasant hours at 'speculation' in my time, but I have not been in the way of it for a long while. 'Vingt-un'

1 Memoir, P. 348. 
is the game at Osborne Castle. ${ }^{1}$ I have played nothing but 'Vingt-un' of late. You would be astonished to hear the noise we make there-the fine old lofty drawing-room rings again. Lady Osborne sometimes declares she cannot hear herself speak. Lord Osborne enjoys it famously, and he makes the best dealer without exception that I ever beheld-such quickness and spirit, he lets nobody dream over their cards. I wish you could see him over-draw himself on both his own cards. It is worth anything in the world!"

We may surely recognise the folly and underbred parade of Mr. John Thorpe in Mr. Tom Musgrave's speech. Again, Tom Musgrave plagues Emma just as Thorpe persecuted Catherine by an ill-timed invitation to a tête-a-tête curricle drive.

The heroine, Emma Watson, has no resemblance to Emma Woodhouse. In situation she may be compared to Fanny Price, for she has been brought up by a refined aunt, and is suddenly plunged into the very different manners and surroundings of her pushing jealous sisters; but in character she seems to me to have none of the charm which has given Fanny Price such various admirers as the Rev. Sydney Smith and Mr. F. W. H. Myers. ${ }^{2}$ It is perhaps characteristic of her creator's truth, that her heroine who is made known to us just as she arrives at her new home in uncomfortable surround-

1 Not the Royal residence of that name.

${ }^{2} \mathrm{Mr}$. Austen Leigh, Memoir, p. I40, quotes from Sir Denis Le Marchant that Fanny Price was a "prime favourite" of Sydney Smith. Mr. F. Myers I remember speaking to me of his especial admiration for Mansfield Park and Fanny. 
ings and among unknown sisters, should be reserved and a little prim, and that we should be made to feel that this was not her complete character. Possibly she would have developed into a Fanny Price with a strong touch of Eleanor Dashwood, but this is a barren speculation.

Another unfinished novel was begun in January, 1817 , and twelve chapters were written by the middle of March. Miss Austen died on July 18 of that same year. This unnamed novel, to judge by extracts published in the Memoir (p. I8I), promised to contain at least one admirable character in the person of Lady Denham, who seems an ill-natured and grasping Mrs. Jennings (if that is not a contradiction in terms), with a strong flavour of Lady Catherine de Burgh.

Miss Austen's works are not only to be studied from the point of view of genetics, nor merely by a naturalist whose desire is to classify without inquiry as to the origin of his species; they also supply material for the geographer. I do not know who first identified the Highbury of Emma with Cobham, as being seven miles from Boxhill and 18 from London ("sixteen miles, nay 18 , it must be full 18 to Manchester Street"). The identification is confirmed by a slip on the part of the authoress, who, in a single passage, printed Cobham in place of Highbury. By this method of mensuration my friend the Master of Downing has shown Kellynch Hall in Persuasion to be near Buckland St. Mary, and Mansfield Park to coincide roughly with Easton, near Huntingdon. The geography of Lyme Regis is of interest. 
The party from Upper Cross drove in a leisurely way to Lyme, and the afternoon was well advanced as they descended the steep hill into the village. The hill is doubtless much as it was, and nearly at the bottom are the two hotels mentioned; it is, honestly speaking, impossible to say at which of the two the Musgroves put up. I am inclined to believe it was that on the west side, but my reasons, if indeed they exist, are not worth giving.

The house in which Miss Austen is known to have stayed is probably Captain Harville's. It is near the Cobb, and presents that air of not having much room inside, which we gather from the description in Mansfield Park.

But these points are of trifling interest in comparison with the really important question-where did Louisa's accident occur? There are three separate flights of steps on the Cobb, and the local photographer, in the interests of trade, had to fix on one of them as the scene of the jump. I cannot believe that he is right. These steps are too high and too threatening for a girl of that period to choose with such a purpose, even for Louisa, whose determination of character we know to have been one of her charms. Then, again, this particular flight is not (so far as I could make out) in the New Cobb, which is where the accident is described as occurring. It is true that at first sight it hardly looks dangerous enough to bring about the sight which delighted the fishermen of Lyme, namely, a "dead young lady," or rather two, for the sensitive Mary contributed to the situation by fainting. I am, however, confirmed in my belief 


\section{JANE AUSTEN}

by what happened to myself, when I went to view the classic spot. I quite suddenly and inexplicably fell down. The same thing happened to a friend on the same spot, and we concluded that in the surprisingly slippery character of the surface lies the explanation of the accident. It had never seemed comprehensible that an active and capable man should miss so easy a catch as that provided by Louisa. But if Captain Wentworth slipped and fell as she jumped, she would come down with him.

I am told that when Tennyson visited Lyme he repelled the proposals of his friends, who wished him to see something of the beauties of the place, and insisted on going straight to the flight of steps. This is an attractive trait in Tennyson's character, but it may not have been pleasing to his hosts. 
VI.

\title{
THE EDUCATION OF A MAN OF SCIENCE
}

\author{
An Address to the Association of University \\ Women Teachers, January 13, 1911
}

In the following pages I propose to give my own experience of education, that is to say, not of educating others, but of being educated. It seems to me that the education of one's youth becomes clear to one in middle life and old age ; and that what one sees in this retrospect may be worth some rough record and some sort of criticism. One may, of course, be mistaken about what was bad and what was good in one's training. But the experience of the pupil is, at the least, one aspect of the question. And I think that the memories of how we were taught is something much more definite and vivid, something that can be more easily made interesting to one's readers, than the generalised experience gained as a teacher.

Any record of education which extends fifty years back has a certain value, and my experience may serve as a stepping-stone to that of my father, of which we fortunately have an account in his own words, and these take us back to a period more than one hundred years ago.

Those of us who are inclined to despair over education as an inherent misfortune of youth, may 
be encouraged by this putting down of milestones, and may almost believe that we have moved in the right direction. Whereas, to those optimists who are cheerfully and unhesitatingly educating their allotted prey of children, it may be as salutary, as a cautionary story, to realise that the same optimism ruled one hundred years ago, when the Eton latin grammar was a symbol to innumerable complacent schoolmasters of what was best in the best of all possible worlds. But the chief part of what I have to say is autobiographical, and I have only an occasional remark to make on the progress and improvement that have occurred in education. -.. My ignorance of educational methods may probably lead me to repeat what is well known; because what seems to me bad in my training has doubtless been recognised as such by modern teachers, nor can I hope to have anything very new to say about what seems to me to have been good.

As children, we, my brothers and sisters, were treated by our parents in a way the very reverse of the pitiless i 8 th and early igth century mannerthe spirit of those surprising stories such as the Purple Jar, where the child is deceived by her abominable parent. In fact, a chief characteristic of our parents' treatment of us was their respect for our liberty and our personality. We were made to feel that we were " creatures whose opinions and thoughts were valuable to them."

The happy relations with our elders which we enjoyed in the holidays to some extent counteracted the evil effects of going to school. The worst of a boarding-school is that it is a republic 


\section{EDUCATION OF A MAN OF SCIENCE}

of children, where the citizens are saturated in the traditions and conventions peculiar to themselves, and are, for more than half their lives, deprived of the saner ideals of grown-up people. Before we went to school we were taught by governesses. I cannot help wishing that we had had foreign teachers who would have taught us to speak their language-a thing that can be done so easily in childhood. I have never got over the want of fluent French and German, and I resent the fact that I should be condemned to feel like a child or a boor in the presence of foreigners. We are taught Latin and Greek because, as we are assured, they introduce us to the finest literature in the world. To most boys they do nothing of the kind, and are an intolerable burden. French and German taught by the oral methods really do introduce us to whole nations of minds that are otherwise cut off from us ; and not merely minds mirrored in books, but more especially those of human beings as given in speech.

This is all very familiar, I only mention it because it is a special case of a wider question, namely: How much can be safely poured into a receptive child which he will be thankful for as he gets older? I mean, rather: What is the proportion that ought to be maintained between learning to reason, e.g., Euclid; exercising the attentive faculties, e.g., in plodding through a Latin book with a dictionary; and the more or less mechanical acquirement, as in learning by heart? Why was I not taught addition by memorising tables as in the case of multiplication? It could 


\section{EDUCATION OF A MAN OF SCIENCE 8I}

have been built into the structure of my mind equally well, and would have saved much misery. It is, of course, essential that what is learned should be true. I have heard a credibly attested story of a dame-school at the beginning of last century, where class and teacher were heard chanting together: Twice $I$ is 2 , twice 2 is 3 , twice 3 is 4 , etc.

I certainly believe in learning by heart, and I am grateful for having learned many dates at school; most of them are forgotten, but enough to be of some use are retained. The worst of it is that I am as likely to know the date of the Flood as that of the Fire of London, and of the battle of Arbela as that of Worcester.

I am also grateful for having been made to learn Shakespeare by heart, although we had to do it before breakfast. I do not imagine that I now remember any of it, but it gave me some idea of the beauty of literature, which I hardly gained at all from the classics. It also started me reading Shakespeare out of school. I believe this is the easiest way of supplying some modicum of literature to a boy who cannot get it out of Latin and Greek. And a kind of Cowper-Temple Shakespeare, without note or comment, is more effective than regular so-called literary lessons, and the worrying of boys about the metre or the difference between a hawk and a handsaw. A boy does not want to understand everything, and he likes to get his poetry in a book which looks as if it were meant for reading, not for cramming or for holiday tasks. 


\section{EDUCATION OF A MAN OF SCIENCE}

Personally, I also resent that I was not taught at school to read music by the sol-fa system, which is another of the things that can be poured into most children not only easily but with pleasure to themselves. I have been assured by a learned musician, that in the 17 th century reading music was as much a sign of culture as reading a book. There was recently an excellent letter in the Times ${ }^{1}$ on public school music, pleading that boys should be allowed to drop, let us say greek iambics, and devote the time to serious musical study. The writer describes how at a certain school a good professional orchestra gives a concert once in each term, for which the boys are prepared by having the themes of the movements, e.g. of a Beethoven symphony, played over to them on the piano and expounded. He describes how an athletic boy, a member of the football team, declared, when the concert was over, that there was nothing to live for during the rest of the half, apparently not even football. No wonder that the writer of this letter should respectfully deride a former Head Master of Eton for his approval of choral singing, on account of its "moral and political value."

I have always felt that the best teaching I received was in two practical matters, viz., how to play the flute, and how to use a microscope. It may be said that these were subjects in which I took a natural and spontaneous interest, and were therefore easily taught. This is no doubt partly true, but I do not think it depended on any special attraction

1 Times, Dec 6, Igro, Educational Supplement. 


\section{EDUCATION OF A MAN OF SCIENCE 83}

for music or microscopy, but on something wideron the novelty of being taught to do something physical, something with one's hands and ears and eyes. I am sure boys ought to have more practical teaching-not necessarily in science, but such things as mild carpentering, the tying of knots, and such exercise in rough weighing and measuring as would form a basis for a little elementary physics. The same is true of girls, and in one way they need handiwork more than boys. I found, in my Cambridge class of practical plant-physiology, that the girls had not such 'deft fingers' as their brothers; I believe the difference is largely due to the boys having played with string and knives, etc., for many idle hours. Both boys and girls must be taught to use, not only their hands, but their eyes. It seems to me piteous that when I was at school there was absolutely nothing done to keep alive the natural sharp-eyedness of children. I remember vividly the intense pleasure which my father gave me (a very small boy) by showing surprise at my knowledge of common trees and shrubs in a winter coppice. I am sure that school did much to kill the power of observation in me.

It may be that observation is an essentially transitory quality, a fleeting ancestral reminiscence, a trail of glory, like other savage traits in children. But more than now survives might be preserved to us by training at school. It ought not to be possible for a boy to come up to a University so blind and helpless as to describe a wall-flower (which has six obvious stamens arranged in a striking pattern) as having "about five stamens." 


\section{EDUCATION OF A MAN OF SCIENCE}

Yet this I experienced in an examination of medical students. Describing an object placed before him is excellent training in observation for a boy. And the capacity of describing an object by memory should also be cultivated. Remember what Dr. Noel says in Stevenson's story of the Saratoga Trunk, and how we may fail in a question of life and death because we cannot descriqe the mysterious stranger who dogs our footsteps.

To return for a moment to the description of an object. It not only practises the power of observation, but is also excellent exercise in writing English, far better as it seems to me than the usual essay on the usual subjects. In describing a given object the pupil has not to seek for material-it is there before him. He need not recall his feelings during a country walk, or the way he spent his time in the Christmas holidays, or vainly search for facts on the character of Oliver Cromwell. He can concentrate on arrangement, on directness and clearness. My experience of the essays set to candidates in the Natural Science Tripos was most depressing. A man who could write a good plain answer to an ordinary examination question becomes ornate and tiresome when he is told to write an essay. Such candidates have clearly never heard the admirable statement by Canon Ainger of the style expected in writers in the Dictionary of Natural Biography, "No flowers by request." Nor can they have known that other bit of advice, "You have no idea what strength it gives to your style to leave out every other word." I have heard suggested another method of checking the natural 
EDUCATION OF A MAN OF SCIENCE 85

diffuseness of the youthful essayist, namely, to make him confine himself to a definite number of words, I have even heard an essay on a post card recommended.

For myself, I believe the best exercise in English I ever had was the correction of my father's proof-sheets. What I found so educational was the necessity of having to explain clearly and exactly why I objected to a given sentence, since I naturally could not baldly express my disapproval. It was not only good training, but as has been well said by my sister (who also helped in this way), "It was inexpressibly exhilarating to work for him"and she continues-referring to the generous way in which he took our suggestions, "I think I felt the singular modesty and graciousness of his nature through thus working for him in a way I should never otherwise have done."

How far every boy ought to be made to do mathematics (beyond simple arithmetic) I cannot say. I know that I am extremely grateful for the small amount of mathematics forced into me. I am even thankful for a very mechanical side of the subject, namely, the use of mathematical tables in general, and for being compelled to work out innumerable sums by logarithms, which we had to do in a "neat tabular form" to quote our precise master's words.

Certainly my opportunities were strikingly better than my father's, who records that at Shrewsbury School nothing ${ }^{1}$ was taught but classics,

${ }^{3}$ See, however, a footnote in No. Ix. of this volume, P $14 \mathrm{I}$. 


\section{EDUCATION OF A MAN OF SCIENCE}

ancient history and ancient geography. Euclid, which he liked and felt to be educational, was taught by a private tutor who had the attractive characteristic of wearing top boots.

I now pass from general education to the teaching of science. When I went to Cambridge in 1866, the teaching, as far as the biological sciences went, was in a somewhat dead condition. Indeed, I hardly think it had advanced much from the state of things which existed in 1828 , when my father entered Christ's College. Cambridge was a turning point in his scientific life, chiefly through Professor Henslow's discovery that the youth, whom his father Dr. R. W. Darwin thought likely to be a mere sporting man and a disgrace to his family, was really a remarkable person, possessed by a burning zeal for science. Henslow made a friend of my father (he was known as the "man who walks with Henslow"), and recommended him as naturalist to the "Beagle," where he was made into a man of science.

In my time there were two ways of acquiring knowledge: attending the lectures of University professors, and going to a coach. Lectures, as my father has said, have "no advantages and many disadvantages . . . compared with reading." And the same view (or heresy as he confesses it to be) has been well given by the late Henry Sidgwick in his Miscellaneous Essays (1904). He holds that a purely expository lecture, without experiments or specimens, is something very like a barbarism, an echo of the days before printing was invented. He points out too how there is every temptation to the 
EDUCATION OF A MAN OF SCIENCE 87

teacher not to publish his lectures. Thus the students who live elsewhere, and therefore cannot attend his course, "are deprived of useful instruction," and the students who do attend them have to receive it in an inconvenient form, in order that the Professor may be enabled to fulfil with éclat the traditional conception of his function (op. cit., p. 347). One set of lectures, which as a medical student I was compelled to attend, were so dull that I literally could not listen to them, but I got into a quiet corner and read Swift's Journal to Stella, and for that opportunity I am certainly grateful.

A course I thoroughly liked was that given by the late Sir George Humphry, the Professor of Anatomy. He used to sit balancing himself on a stool, with his great hungry eyes fixed on us, talking in plain direct terms of anatomy enlivened by physiology. The one point that remains with me is the way in which he would stop and wonder over the facts he brought before us: "This is a wonderful thing, one of the most wonderful things in the world, I know nothing about it-no one knows-you had better try and find out, some of you "; simple words enough, but they struck a chord of romance in some of his hearers. I remember another teacher of anatomy in London who stirred our wonder in quite another way, for he made us marvel how any man could repeat by heart Gray's book on Anatomy for an hour, and wonder too, why we should be compelled to listen.

The private tutors or coaches to whom most Cambridge students of natural history went were, as far as my experience went, hopelessly bad. My 


\section{EDUCATION OF A MAN OF SCIENCE}

coach tried to ensure that I knew certain inferior books well enough to be examined in them, but he never showed me a specimen, and never attempted to ensure that I should have any sort of first-hand knowledge. We were also taught by the Curator of the Botanic Garden, a completely uneducated man, and in all ways as different from the present learned and cultivated Curator as it is possible to imagine. He, like my other coach, simply insisted that we should know by heart a very bad text-book, on which he cross-examined us as we walked round the Botanic Garden. As far as my recollection goes he never stopped to show us a flower or a leaf, and we had nobody to help us to a sight of the minute structure of plants as seen with a microscope, about which, however, we could talk eloquently from the book.

I sometimes wonder that fire did not descend from heaven and destroy a University which so sinned against the furst elements of knowing, in neglecting the distinction between what we learn by our own personal experience and what we acquire from books.

Of course there are some sciences which have their origin in practical matters, e.g., chemistry, which originated partly in alchemy and partly in what is now the work of the druggist; such a science was fortunate, in that no one objected to its claim for practical teaching. Nevertheless, the student of chemistry in my day easily fell into a lamentable dulness of different coloured precipitates. I should have liked to do something quantitative, however rough, to get away from the 
everlasting test-tube, and to make, for instance, some of the historic experiments with gases.

Human anatomy again was always taught practically, i.e., by work in the dissecting-room. But owing to the manner in which medical students were examined, the subject failed to have the value it might have had; minute questions were asked which no amount of dissecting would enable us to answer. The book had to be learned by heart, and I shudder as I remember the futile labour entailed. And the examination was so arranged, that whilst we were "cramming" anatomy we had also to suffer over another subject, materia medica, which was almost entirely useless, and wearisome beyond belief. Much of it was about as rational a subject to a physician as to a surgeon would be a minute knowledge of how his knives were made and how steel is manufactured. I remember how, after getting through this double ordeal of cram on drugs and on the structure of the body, I heard a surgeon say in lecture : "This is one of the very few occasions on which you must know your anatomy." I recall the anger and contempt I then felt for the educational authorities, as I remembered the drudgery I had gone through.

The want of organised practical work in zoology was perhaps a blessing in disguise. For it led me to struggle with the subject by myself. I used to get snails and slugs and dissect their dead bodies, comparing my results with books hunted up in the University Library, and this was a real bit of education. I remember too that a thoughtful brother sent me a dead porpoise, which (to the 


\section{EDUCATION OF A MAN OF SCIENCE}

best of my belief) I dissected, to the horror of the bedmaker, in my College rooms.

Then the late Mr. Clark, superintendent of the Museum of Zoology, and one of the kindest of men, occasionally gave us beasts to cut up. I shall never forget my pride of heart when a preparation which I made of a hedgehog's inside was placed in the Museum.

Just as I was leaving Cambridge in 1869 or, '70 there arrived that great man, Sir Michael Foster, who organised the revolution in which the futilities of the early igth century were blown to fragments, and in their place a sound system of practical instruction was created. Foster was discovered by Huxley, and it was through him, and thanks to the patriotism of Trinity College in creating for him the post of Praelector, that Foster got this great opportunity. The effect of what he did for English education has been incalculably great. His pupils have gone forth into all lands, and have spread the art of learning and teaching wherever they have come to rest.

In thinking over the reformation wrought by Michael Foster I am somehow-quite inconsistently-reminded of the great scene in Guy Mannering. I see in imagination the cold dark cave at Warroch Head, where Dirk Hatteraick lurks; he plays the part of False Science in the Mystery Play, and the cave is the Cave of Inanity. Then comes the great flare of light, as Meg Merrilees throws the torch on to the heap of flax, and her cry, "The hour is come and the man!" while Harry Bertram with his supporters rush in and bind False Science fast. 
EDUCATION OF A MAN OF SCIENCE 9I

Harry Bertram is, of course, Michael Foster, and I should say that Dandie Dinmont is Coutts Trotter. Meg Merrilees is naturally Huxley, who was the magician of the affair (she is always said to have looked like a man). Here all analogy breaks down. Meg was killed by False Science, Huxley was not; indeed it was the other way. Harry Bertram lived happily ever afterwards. Michael Foster was not so fortunate, and I am ashamed to think that before he died he was misunderstood and half forgotten in his own University.

I must apologise for this outburst of incoherence; I am afraid it was not this sort of thing that Tyndall had in mind when he pleaded for the scientific imagination-that is something much more serious.

Not only does the student of to-day get good practical teaching, but he has the great advantage of being under professors who are generally engaged in original work. And if a man can afford the time to stay up after his degree, he is encouraged and helped to undertake research. If practical teaching is the foundation, the protoplasm as it were, of scientific education, I am sure that original work is its soúl or spirit.

Whether, like my father in South America, we have the genius to solve big problems in geology and "can hardly sleep at night for thinking of them," or whether, as with us smaller people, the task is some elusive little point which we triumphantly track to its cause, there is an extraordinary delight in such work. Professor Seward arranged an admirable imitation of original research in his 
advanced class on the anatomy of plants at Cambridge. He gave out specimens which the students had never seen ; these had to be investigated, and they had to give viva voce accounts of their discoveries to the rest of the class. I believe this to be a method worth imitating, and I may say as an encouragement to women teachers that it was a Newnham student who was especially distinguished in this mutual instruction class.

When I left Cambridge and became a medical student in London, I had the luck to work in the laboratory of Dr. Klein, who was then head of the Brown Institute at Nine Elms. He was fresh from Vienna, with all the continental traditions in favour of original research. Even in the ordinary laboratory work I remember how he tried to throw the romance of practicality over my task. He rushed in one day with a large bread-knife stained with blood in the most sinister manner, saying that a murder had occurred in South Lambeth, and it was for me to determine whether or no the red fluid on the blade was blood!

Later on he set me to work investigating inflammation, and I can still remember his praise of the harmless little paper I wrote. To my secret satisfaction he blamed me for the severity of my remarks on a German Professor who had written on the subject. He told me to strike out my criticism, though he allowed it to be just. I sighed as an author, but obeyed as a pupil,--to misquote the words of Gibbon.

Education is often spoken of, and is praised or blamed, as a method of imparting information to 


\section{EDUCATION OF A MAN OF SCIENCE 93}

the young. It is obvious that it is far more than this. It includes the stimulation of tastes, tendencies, or instincts which are inherent but dormant in the pupil. In my case the opportunity, so wisely and kindly given by Dr. Klein, of seeing science in the making-of seeing research from the inside-his giving me the delight of knowing that I had added a minute fragment to the great raging flood of publications which marks the progress of knowledge-all this was a potent factor in my education in the wider sense. That is, it did not merely teach me certain facts, but woke in me the desire to work at science for its own sake. My father finally gave me the necessary opportunity by taking me as his assistant.

No one should ever be able to finish the history of his own education, because it is co-extensive with his life. In my father's autobiography written shortly before his death, he attempts to sum up the effect of this self-education on himself, both as concerns his experimental research and also in regard to the literary part of his work. An instance of his modest estimate of his own mental progress, is so characteristic that I shall venture to quote it. "I think that I have become a little more skilful in guessing right explanations and in devising experimental tests; but this may probably be the result of mere practice, and of a larger store of knowledge. I have as much difficulty as ever in expressing myself clearly and concisely; and this difficulty has caused me a very great loss of time; but it has had the compensating advantage of forcing me to think long and intently about every 


\section{EDUCATION OF A MAN OF SCIENCE}

sentence, and thus I have been led to see errors in reasoning and in my own observations or those of others." I repeat that self-education is an endless task. To some men this is a comforting, to others a depressing, fact. Samuel Johnson was, I think, saddened by the making of fresh plans of conduct for each new year. A very different man, though also a Samuel,-Butler, the author of Erewhon, was cheered by the thought that it was always possible to improve. When I knew him he was working as a painter in an untidy room in Clifford's Inn, without much furniture except a piano. He was poor, and therefore, to save models, painted himself over and over again, the result being a cupboard full of grim heads, which he called the chamber of horrors. He always believed he should succeed at last, and the point I am slowly reaching is that he comforted himself with the belief that John Bellini entirely altered his style when he was between 60 and 70 years of age. One of the French aphorism writers, Vauvenargues, has said (as translated by Lord Morley), "To do great things a man must live as though he had never to die. ${ }^{1}$ I too would recommend the wholesome theory that it is never too late to learn; it helps to keep one from falling too soon into incurable fogeydom.

In the lives of big men it is sometimes possible to see how work done for its own sake may turn out to have had its real value as a piece of training for something of far greater worth. Thus my father

1 Studies in Literature, 189r, p. 100. 
EDUCATION OF A MAN OF SCIENCE 95

began in 1846 working at a curious Cirripede, i.e., a barnacle, which he had found on his voyage; this led him to examine others, and in the end he worked seven or eight years at this group of animals.

To his children the habit of working at barnacles seemed a commonplace human function, like eating or breathing, and it is reported that one of us being taken into the study of a neighbour, and seeing no dissecting table or microscope, asked with justifiable suspicion, "Then where does he do his barnacles?" When I was writing my father's Life, I asked Mr. Huxley his opinion whether this seven or eight years' work had been, in his judgment, worth the great labour involved. His answer was that no man is a good judge of the speculative strain which may be put on the raw materials of science, unless he knows at first hand how this raw material is acquired, and this knowledge my father gained by his barnacles. The Origin of Species is the evidence that he did not miscalculate the strain his facts would bear, for his theory is as strong as ever.

There is one influence, of the greatest importance in regard to' education, with which I have not attempted to deal. I mean the personal influence of the teacher. This is a part of the pupil's environment which not even a millionaire can undertake to supply to his pet University. It is rather a thing to pray for, and to treasure when the gods send it to us.

There is a magic in the personal effect of a great teacher, which makes it comparatively unimportant 


\section{EDUCATION OF A MAN OF SCIENCE}

what sort of science he teaches. In him the How entirely dwarfs the What.

To take an instance. My father's master, Professor Henslow, was of this type. But some of his advice was extremely bad. Thus he told my father to read Lyell's Principles, but on no account to believe the theoretical parts of the book. In spite of the warning, my father was at once converted to the doctrines set forth in the Principles, and Lyell was from that time forward the chief influence of his scientific life. But his gratitude to Henslow remained fresh and strong to the day of his death.

The same thing is true of Lyell and hisinstructors. When he left Oxford and went down to Scotland geologising, he must have been full of Buckland's teaching, and ought to have believed that the surface of the county of Forfar was just as the Flood left it, some few thousand years ago. But he at once proceeded to discover in Noachian Forfarshire the most striking evidence of geological change actually in progress. So that, under the influence of a great catastrophist, Lyell became the greatest of the uniformitarians, and more than any one man was the destroyer of the older point of view.

The personal effect of teacher on pupil cannot be bought at a price, nor can it be paid for in any coin but gratitude. It is the possibility of earning this payment that makes the best part of a teacher's life. 
VII.

THE PIPE AND TABOR

An Address to a Society of Morris Dancers, Oxford, February 12, 1914

In the following pages I have brought together some scattered information on the instruments, especially connected with Folk-Dancing, which give the title to my address. The coming to life of a mass of beautiful tunes and dances, in response to the patient search of Mr. Cecil Sharp and a few others, is one of the most magical occurrences of which I have any memory. In a less degree I have experienced the same sense of the unexpected, in learning that in a Kentish village, so near London as often to be darkened by the skirts of town fogs, the ancient superstition still existed of telling the bees that their master is dead. Such an unsuspected lurking of primitive belief in our midst may well give a shock of surprise. But in the resurrection of the mass of hidden music, and of the dying traditions of dances, a web of extraordinary beauty is suddenly revealed-a matter of real importance.

If tunes have souls they are shut out by death from ever again vibrating in a human tenement. They are like the gabel-rachels, the souls of unbaptised infants whom men in Yorkshire used to hear crying round the church as though begging 
to be let in. But the traditional tunes of England are no longer homeless ; they have a safe refuge in the printed page. They have become immortal, or as near immortality as modern paper can insure.

Mr. Sharp has done wonderful things; he is like a naturalist who should discover that we are unconsciously surrounded by whole races of beautiful things as unknown to us as elves and fairies. In the Commemoration Service we speak gratefully of all those who "found out musical tunes." If ever a man deserved remembrance for literally finding out tunes it is Mr. Sharp.

But to return to the musical instruments of the Morris dancers-the Pipe and Tabor. I am told that the little drum on which the piper accompanies his tune should be pronounced 'tabber.' I have no doubt this is right. The Oxfordshire name Dub suggests it, and the old French word Tabour is something of an argument in the same direction. In Wright's Dialect Dictionary it is said that the lesser spotted woodpecker is called the "tabberer" from its habit of drumming on tree trunks. I should like to call my pipe a "tabberer's" pipe if only out of affection for the little black and white bird and his drum, but the modern pronunciation, with a long $a$, has a strong hold and can hardly be ousted. We nowadays put the pipe before the tabor, but in Shakespearian days this was not so. In The Tempest Ariel plays the tune "Flout'em and scout 'em" on a tabor and pipe-and the artist was called a taborer $^{1}$ not a piper. In the same way

1 The military drum and fife band is spoken of as "the drums" ; there is no such person as a fifer, he is described as a drummer. 


\section{THE PIPE AND TABOR}

the Provençal performer on the two instruments was (according to Daudet), and I hope still is, known as the tabourinaire.

Morris dancing, for which the tabor and pipe once supplied the music, is now an everyday accomplishment. At Cambridge one may see Fellows of Colleges dancing, waving handkerchiefs and knocking sticks in the old manner, and I hope the same is true of Oxford.

But piping is not so common. Some of us have heard Mr. Sharp at a lecture, or Mr. Haydn Coffin on the stage. But it is not an art likely to spread rapidly, because the old English is pipe rare and hard to come by, and copies are not common either.

I began to learn the taborer's art on a French or Basque galoubet obtained in Oxford from that kind friend of many musicians, the late Mr. Taphouse. But it was only quite recently, when Mr. Manning lent me an old Oxfordshire instrument and allowed me to have it copied, that I made any kind of progress.

I do not know when playing the "whittle and dub" (as they were called) became extinct as a village art. It certainly existed thirty years ago, and for all I know there are still some living who could hand on the grand manner of taboring. Mr. Taphouse remembered very well the days when the pipe and drum were heard all round Oxford at fairs and village festivals. I remember his showing me a whittle with a crack in it where it had been broken over the head of a reveller by a drunken taborer. 
The two instruments have been generally associated with dancing. 'Tans'ur ${ }^{1}$, writing in 1772 , speaks of this. "The Tabor and Pipe are two musical Instruments that always accompany each other, and are mostly used at Wakes by Country People, and at their Dancings and innocent Diversions, and often with Morris Dancers." He speaks of the pipe as played with the left hand, "on which Wrist hangs a small drum, braced in Tune to the Pipe, and beat by the Right Hand as a Bass in Time to it : both of which being well managed make pretty Harmony."

In the Wallace Collection there is a picture by N. Lancret (1690-1743) of a celebrated dancer, Mme. Camargo, who is accompanied by a small orchestra of two recorders, a bassoon and one or more viols; these are partly hidden at the back of the scene, while a boy with pipe and tabor ${ }^{2}$ stands close to the dancer, giving the impression that she depends on him rather than on the more formal musicians in the background. It may remind us of the Duke of Plaza Toro, who sings a song accompanied and supported by his own particular private drum as well as by the orchestra. The same quasi independence of the tabor and pipe is still to be found in the folk music of the Catalans, the inhabitants of the north-east of Spain. The dance

The Elements of Musick Display'd, etc., by William Tans'ur, Senior Musico Theorico, London, I772, p. I03.

${ }^{2}$ It is a pleasure to express my indebtedness to Mr. Cockerell, Director of the Fitzwilliam Museum at Cambridge, for his kindness in searching, in my interest, for old illustrations of the pipe and tabor. I have given some account of them in an appendix to this essay. 
which Mr. Casals-himself a Catalan-described to me, is a round dance of some complexity. It is held in high esteem as a national affair, and is danced by gentle and simple together. The band consists of a tabor and pipe, four large rustic oboes, some cornets and a double-bass. The interesting point is that the taborer always leads off with a solo, a spirited flourish which Mr. Casals was so good as to play on the piano. It is curious that there is only one such traditional flourish, and this is used whatever the dance-music may be. Mr. Casals described the effect of the whole band as moving and exciting in a high degree.

I have an old newspaper cutting of the Queen Victoria and Prince Albert watching the British sailor dance a hornpipe on the deck of a man-ofwar, accompanied by a couple of marines with a drum and fife. Shakespeare evidently considered these two instruments as the military equivalent of the tabor and pipe. He makes Benedick laugh at Claudio, in love, for throwing over the drum and fife for the taborer's music.

In the middle ages the tabor and pipe were a good deal associated with the performances of strollers and mountebanks. On the other hand, they did not always take this rôle. There is a beautiful carved figure playing the pipe and tabor in the Angel Choir of Lincoln Cathedral, dating from 1270. In Strutt's Sports and Pastimes (Ed. 2, Plate XXIV), a horse is shown, dancing to a tabor and pipe, from a MS. of about 1300 ; on Plate XXIII is a drawing of a taboring hare (without a pipe) of about the end of the i 3 th century. I am not 
aware that these instruments are known to have existed in England earlier than the 13 th century.

Fra Angelico puts these instruments into the hands of an angelic lady. Her tabor is beautifully given, the pipe is but slightly indicated. In Florence, among the singing boys of Luca della Robbia (reproduced in fig. 5), is to be found the best representation of a pipe player that I have seen. There is a comparatively modern picture of Will Kemp, ${ }^{1}$ the Shakespearian actor, performing his dance to Norwich. He started, apparently in 1599, on the "first Monday in cleane Lent," and succeeded in his object, though not without difficulty. His attendants' names are pleasant : Taborer, Tom Slye, Servant, Wm. Bee, Overseer, Geo. Sprat.

I am glad to say that a tabor and pipe appear in one very honourable secular affair, ${ }^{2}$ namely, a tournament, more correctly a joust or single combat. One of the combatants is supported by a bagpipe, the other by a tabor and pipe. It must be confessed, however, that the taborer was not well treated in mediaeval times, badly paid, and not received with the honour given to minstrels.

I like the rustic character of the pipe, and its association with cheerful mediaeval vagabonds, and, still more, its memories of centuries of village dances. I wish it had found a place in that "dancing in the chequered shade," in which Milton

1 Kemp's Nine Daies Wonder: Performed in a Daunce from London to Norwich, by A. Dyce, Camden Society, I 840 .

${ }^{2}$ See Strutt's Sports and Pastimes, Edit. 2, 1810, Plate XIV.. p. 124 . 


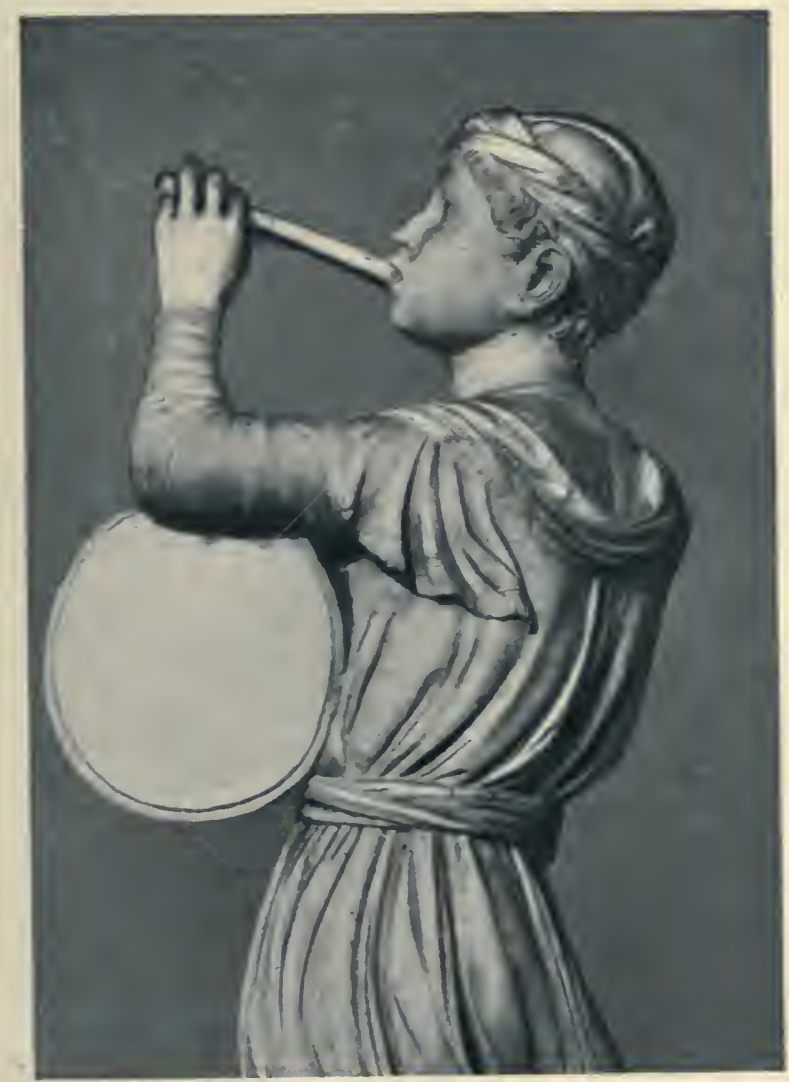

Fig. 5.-Pipe and Tabor.

After Luca della Robbia: in isolating the figure it acus nccessary to complete the drum and part of the drapcry. 

has immortalised the jocund rebecks. But Milton was a player of the bass viol, and does not show any especial feeling for wind instruments, so at least I gather from Welch's interesting book. ${ }^{1}$

The taborer's pipe is a whistle ; it happens to be made of wood, but its musical structure is precisely that of the penny whistle, except in one important particular, that it has but three holes in place of six. The pipe is therefore a poor relation of that beautiful but extinct instrument the recorder ${ }^{2}$ which is only a wooden whistle. The recorder has a low, hollow, but most effective tone, and I shall never forget the ravishing effect of a quartet of recorders as played at a concert given by $\mathrm{Mr}$. Galpin, the well-known authority on old English instruments. The taborer's pipe has none of the sweetness of the recorder ; it is essentially a shrill instrument ; indeed, I am told by a philologist that its old German name Schwegel contains a root implying shrillness. Another old German name is Stamentien Pfeiffe, which my philological friend tells me does not occur in the best German dictionary, and is of unknown origin.

As I have said, the pipe has but three holes (stopped by the index, middle finger and thumb); these give four fundamental tones, which however do not occur in the working scale of the instrument.

1 Welch, Christopher. Six Lectures on the Recorder and other fiutes in relation to Literature, I9II, P. 255.

2 Recorders used to be known as flutes, while what we call flutes were described as German or transverse flutes. Purists desire to revive this nomenclature, and would call the taborer's pipe a finte or fipple-flute. 
In the penny whistle, and most wood-wind instruments, the octave or first harmonic gives the means of extending the scale. But in the taborer's pipe the whole of the workable scale consists of harmonics ; what corresponds to the lower octave in the penny whistle-the non-harmonic or fundamental part of the register-can only be faintly sounded. It is the first harmonic or octave of the lowest of these faint notes that forms the bottom note of the scale of the three-holed pipe. ${ }^{1}$ This note is approximately $\mathrm{D}$ of the modern flat pitch. By successively raising the middle and index fingers and then the thumb, E, F, and $G$ are sounded. Then all the finger holes are again closed, and by a little extra impulse given to the breath $\mathrm{A}$ is sounded, being the harmonic $5^{\text {th }}$ of the lower D. Then follow $B$ and $C$ as harmonic 5ths of $E$ and $F$, and the final $D$ as the octave of the lowest tone. Above this a variable number of notes-about four-are producible by cross-fingerings. The ordinary work-aday scale of the taborer's pipe corresponds to the 12 or 13 uppermost notes of a seven octave P-F., or to the upper notes of a piccolo. The galoubet's scale begins on a B flat one-third below the taborer's pipe. There was also a bass galoubet. This instrument is known from the figures in Praetorius ${ }^{2}$ (1618), and also from one solitary pipe which has

${ }^{1}$ For details of the fingering see the appendix to this article.

${ }^{2}$ Praetorius, Organographia, being the second volume of his Symtagma Musici, 1618, where a figure is given in Plate IX. See Brestkopf and Härtel's reprint of Praetorius, also Galpin's Old English Instruments of Music, xgro. 
escaped destruction. Mr. Galpin has a copy of it in his wonderful collection, and has allowed me to play on it. ${ }^{1}$

Mersenne, ${ }^{2}$ in speaking of the performance of an Englishman, John Price, may give to some unwary reader the impression that the said John could play a continuous scale of three octaves. But it is quite clear that Mersenne included the faint $\mathrm{D}$ an octave below the lowest harmonic note, so that Price could produce an interval of three octaves but a continuous scale of only two octaves. This is not impossible. I can play two out-of-tune shrieking notes above my high $\mathrm{A}$, or I 2 th note, so that I can, after a fashion, get within one note of John Price, and I live in hopes of acquiring yet another and tying with him. The uppermost sounds are made by what was technically known as pinching, i.e. crooking the thumb and forcing the nail into the top hole, so that only a minute stream of air escapes. An old pipe of mine shows the mark of the pinching thumb nail. Mr. Forsyth speaks of "an instrument with only a few notes" as being "much restricted in the way of compass" ": this is not quite just to the taborer's pipe.

In relation to Mr. Forsyth's discussion on the diauloi, it should be remembered that the double pipe still exists in Russia. It is described

1 See also Mahillon, Catalogue descriptif et analytique du Musée instrumental du Conservatoire royal de Bruxelle, I909, Vol 2, p. 282.

${ }^{2}$ Harmonie Universelle, contenant la theorie et la pratique cie la musique, by M. Mersenne, Fol. 1636-7, Vol II, p. 232.

3 Stanford and Forsyth History of Music, I916, p. 44. 
by Mahillon ${ }^{1}$ under the name of the Gelaïka. The fundamental tones of the two instruments are the lower $\mathrm{F}$ sharp in the treble stave, and the B natural above it. Mahillon adds: "tantot elles se partagent la mélodie, d'autres fois elles font entendre des intonations doubles."

With regard to the Greek double-pipe, I am sure that Mr. Forsyth is right, and that the bandage (phorbeia), which is commonly said to have served to compress the cheeks, must have had some other use. I have no doubt that he is justified in assuming that the bandage served to support the instrument. In a pipe with three holes on the upper surface a certain amount of grip on the instrument is given by pressure of the little finger above and the thumb below, and with practice it would be quite possible to manage the instrument. Still, the bandage would give freedom to the fingers, and for the four-holed pipe this form of support would be absolutely necessary. My conclusions are based on experiments on the penny whistle temporarily converted into an instrument for one hand.

In speculating on the evolution of the taborer's pipe, it must be remembered that its harmonics (on which, as I have said, its scale depends) are those of a cylindrical pipe, and a pipe that is long in relation to its bore. I like to think that it had its origin in some of the many natural hollow cylinders found among plants, for instance, the reed grass that grows in fens and dykes, or the elder which supplies a pipe when its pith is bored out, and is

${ }^{1}$ Op. ctt. 1912, Vol 4, p. $21_{4}$. 
perhaps more familiar as the parent of pop-guns than of musical instruments. Then again, there are the hollow stalks of umbelliferous plants, such as angelica and hemlock. The late Mr. Welch, in his interesting book on Recorders, pointed out ${ }^{1}$ that sambucus the elder, calamus the reed, and cicuta the hemlock all occur in classic verse in relation to rustic music. Indeed the word calamus still lives, though corrupted to the French chalumeau and still further altered to the German Schalmei and the English shawm.

Welch doubts whether hemlock or similar stems would be strong enough for the suggested purpose. They certainly would not stand rough usage, but it is possible to make a taborer's pipe out of an Angelica stem, for I have one. It is husky and out of tune, but it shows the thing to be possible.

This connexion between music and the form of plants is not without interest from a wider point of view. We ask ourselves why hollow cylinders occur so commonly in vegetable architecture. That rough teacher, the struggle for life, has taught plants that a tube is, mechanically speaking, the best way of arranging a limited amount of formative or building material. The hemlock or the reed can thus make stalks of ample strength and at comparatively slight cost. There is romance in the fact that plants made tubular stems to their own private profit for unnumbered ages before the coming of man: the hollow reeds waiting all these aeons till Pan should come and make them musical.

3 See p. 267. 
The pipe and tabor have probably come down to us less changed than any other wood-wind instrument, with the possible exception of the panpipes; both flutes and flageolets have become covered with keys, while the pipe still has no more than three aboriginal holes, one for the thumb behind and two for the fingers in front. I have wasted some time in trying to make out how the early taborers held their pipes, but musical instruments are generally drawn with hopeless inaccuracy. I have been rewarded by finding that a boy in Luca della Robbia's bas-relief (Fig. 5) at Florence holds the pipe just as I do, ${ }^{1}$ between the ring and little fingers, which keep the instrument steady even when all three holes are uncovered. There is an interesting point connected with the true or French flageolet. This instrument has six holes arranged in two triads, a thumb and two fingers of the right hand, and the same for the left, so that if all holes are open there would seem to be nothing to steady the pipe. But in $\mathrm{Mr}$. Welch's book (p. 5o) is a figure from Greeting's Pleasant Companion ${ }^{2}$ showing how the flageolet

1 Mr. Galpin, however, uses another grip; he crooks the little finger and presses against the lower end of the pipe, of course without occluding the bore at all. In the early drawings reproduced by Strutt (see ante p. 102) the taborers show as a rule three fingers only. This is practically Luca della Robbia's grip, since the little finger could hardly show in these small illustrations. In Welch's book on the Recorder (p. 195) is a figure (reproduced from Mahillon) of a Basque holding his 3 -holed pipe in a different way, viz., with the ring finger underneath and the little finger unemployed. I find it impossible to hold the pipe in this manner.

2 Various editions appeared from $166 \mathrm{r}$ to $168_{3}$. See Welch, loc. cit., p. $6 \mathrm{r}$. 
should be held, and this, curiously enough, is one of the best views of what I hold to be the proper grip for the taborer's pipe.

The tabor is still much as it was in Fra Angelico's day (judging from the angel above referred to), and indeed in earlier times, as shown in the piping angel in Lincoln Cathedral. We can see what a drum-maker calls the ropes and braces $^{1}$ for tightening the parchment; the snares are also shown in many early drawings of tabors. These are pieces of gut or of horse-hair, stretched across the drum-head, which add a spirited rattle to its tone. Why the first edition of the Dictionary of Music went out of its way to say that the tabor had no snares I cannot guess.

In many of the mediaeval drawings the artist is shown beating his drum on the snare side. I had fancied that this was only one more instance of the bad drawing of musical instruments, but when I saw the careful work of Luca della Robbia, in which the tabors are all beaten on the snare side, I could no longer doubt. I was, however, glad to find in a French account ${ }^{2}$ of the Provençal 3 -holed pipe or galoubet, that this custom survives. In Luca della Robbia's work a single snare-cord is shown instead of four to six catgut lines as in modern drums and this is also true of the Provençal instrument. So that both the characteristics that seemed strange to me in Luca's tabor survive in Provence. drum.

${ }^{2}$ Mr. Galpin says that they are found on an ancient Egyptian

'Mahillon's Catalogue, iii., p. 377. 
It may not be generally known that the French for the snare of a drum is timbre; this is the original meaning of the word, and its familiar use to mean the characteristic tone of a musical sound is later. According to Darmstetter the word 'timbre' is own brother to 'tambour,' both being derived from a low Latin form of tympanum.

The tabor-stick has changed since the early centuries. In some of the old drawings the taborer is striking his instrument with a bludgeon, instead of the light and elegant sticks such as are to be seen in Mr. Manning's collection at Oxford. Such implements were doubtless treasured by the taborer. Valmajour, the tabourinaire in Daudet's Numa Roumestan, possessed a drum-stick which had been in the family for 200 years.

The way of holding the drum has not always been the same. Nowadays we are told to hang it from the thumb or wrist. But in many early drawings it is apparently firmly strapped or tied to the forearm, or even above the elbow. ${ }^{1}$ The Lincoln Angel and Luca's boy have tabors supported by a string round the neck, and this I find to be the best method.

I hope that the drum may long survive in Provence with its ancient companion the pipe. ${ }^{2}$ A different instrument, however, supplies an accompaniment to the galoubet in the Basque provinces. It is a rough sort of lyre with six or

1 A German writer has suggested that this position allows the musician to beat the drum with his head!

${ }^{2}$ According to Mahillon, Catalogue iii., p. 377, to play the tabor and pipe is called in Provençal "tutupomponeyer." 
seven strings tuned alternately to the tonic and dominant, which beaten with a stick make a drone bass to the pipe. It has the attractively savage name of toon-toona, an imitative word like tomtom; the galoubet is called the cherula.

From a French cyclopædia I learn that in Provence the taborer's art was a secret passed on from father to son, a mystery they refused to teach for money. They appeared to hold the patriotic opinion that the art of playing the galoubet, or as they call it, the flitet, has never spread from Provence because of its extreme difficulty. This has been a comfort to me in my attempts to play the pipe and tabor.

\section{APPENDIX I}

\section{Drawings and Carvings of Pipers}

At the risk of being tedious in the way of repetition I have thought it worth while to put together a roúgh list of the illustrations of pipe and tabor which I have met with.

The earliest representation of a player on the 3-holed pipe, of which I have any knowledge, is the beautiful figure in the Angel Choir at Lincoln. Its date is, I believe, I270, and it has been injured so that it is not possible to be sure of the manner in which the pipe is held. The tabor is suspended by means of a string round the neck. 
The most careful representation of our instrument is that by Luca della Robbia, figured at p. I02, in which what I call the correct grip is given. In Pierpoint Morgan's Catalogue of Early Printed Books, Vol II., p. I18, are some illustrations from Gafori, 1492. The pipe is quite incorrectly held, more than two fingers being employed while the thumb is free.

Ibid., Vol III., p. 82. In a figure from Pierre Michaud's Dance des Aveugles, 1485, the pipe has four instead of two holes on the upper surface.

Ibid., Vol III., p. 86. The pipe is incorrect, the holes being too far from the lower end of the instrument; the hand is wrongly given according to our standards, the little finger being flourished in the air. The tabor is suspended from the hand as in the English style, and is struck on the snare side.

In Kemp's Nine Daies Wonder (see above p. 102) the drawing of the pipe is not instructive.

In Strutt's Sports and Pastimes there are several early drawings of performers on the 3-holed pipe. The grip in the majority is correct, i.e. there are three fingers visible, two covering the holes and the ring finger gripping against the little finger underneath. The illustrations are also correct in the fingers being close to the lower end of the pipe.

In Betley Hall, Staffordshire, is a painted glass window, probably dating from 1535, in which a piper is represented. Mr. Tollet, a former squire of Betley, gave an account of it in Johnson and Steevens' Shakspeare, which is reprinted in a privately published book by Barthomley. The pipe is a conical tube, on which four fingers are 
represented; it could not, I believe, have been drawn from a model.

In Mahillon's Catalogue i., p. 375 , is a figure of a Basque playing a 3 -holed pipe, and accompanying himself on the tountouna, a rough stringed instrument. The grip seems to be carefully drawn, but it is hard to see how it could be efficient, only two fingers being seen on the upper surface of the pipe. On the other hand, in a photograph of a Basque playing the same instrument (which I owe to the kindness of a correspondent), the grip is like that figured by Mahillon.

Finally, in Punch, November 13, 1907, a 3-holed pipe is incorrectly drawn. The bore of the instrument is conical, the holes are incorrectly given, and the hand is wrong.

\section{APPENDIX II}

The Fingering of the 3-Holed Piper

The following diagram gives the fingerings which I have found to be best for a 3-holed pipe, a copy of an old one in the possession of $\mathrm{Mr}$. Manning, of Oxford, to whom I am indebted for much kindly assistance.

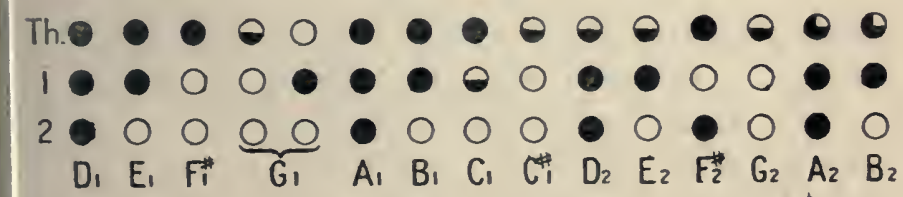

FIG. 6. 
The fingerings are given for the keys $\mathrm{D}$ and $\mathrm{G}$. I have not attempted to play in other keys. For each note the upper circle represents the thumbhole; 1 and 2 are for the first and second fingers respectively. The black circles are supposed to be closed, the white are open. Holes that are half open are represented by circles half white, half black. In the case of $\mathrm{A}_{2}$ and $\mathrm{B}_{2}$ the circles are three-quarter black; this means that a very minute crack is left open.

It is important to remember that each pipe has its individuality. For instance, in one of my instruments $G$ must have the thumb hole completely open, and the alternate fingering (with the index hole closed) is quite out of tune. The note $\mathrm{E}$ is sometimes sharp; in the pipe, the fingerings of which are given in fig. 6 , this fault is corrected by means of a thin metal lining to the lower hole. 


\section{VIII \\ STEPHEN HALES ${ }^{1}$ \\ $1677-1761$}

In attempting to give a picture of any man's life and work it is well to follow the rule of the Dictionary of National Biography, and begin with the dates of his birth and death. Stephen Hales was born in 1677 and died in 1761, having had experiences of the reigns of seven sovereigns.

The authorities for his life are given in my article on Hales in the Dictionary of National Biography. Botanists in general probably take their knowledge of the main facts of his life from Sachs' History of Botany. It is therefore worth while to point out that both the original and the English translation (1890) contain the incorrect statement that Hales was educated at Christ's College, Cambridge, and that he held the living of Riddington, whereas he is one of the glories of Corpus, and was perpetual curate of Teddington. These inaccuracies, however, are trifles in relation to the great and striking merits of Sachs' History, a work which, to my thinking, exhibits the strength and brilliance of the author's mind as clearly as any of his more technical writings. Sachs was no

1 Reprinted by permission of the Syndics of the Cambridge University Press from The Makers of British Botany. 
niggling biographer, and his broad vigorous outlines must form the basis of what anyone, who follows him, can write about the botanists of a past day.

To return to Hales' birth. It is of interest to note how he fits into the changing procession of lives, to see what great men overlap his youth, who were his contemporaries in his maturity, and who were appearing on the scientific stage as he was leaving it.

Sir Isaac Newton was the dominant figure in English science while Hales was developing. He died in 1727 , the year in which Hales published his Vegetable Staticks, a book, which like the Origin of Species, appeared when its author was 50 years of age. Newton was at the zenith of his fame when Hales was a little boy of ro-his Principia having been published in 1687, and when Hales went up to Cambridge in 1696 he must have seen the great man coming from his rooms ${ }^{1}$ in the N.E. corner of the Great Court of Trinity-that corner where Newton's and other more modern ghosts surely walk-Macaulay who used to read, pacing to and fro by the chapel, ${ }^{2}$ and Thackeray who, like his own Esmond, lived "near to the famous Mr. Newton's lodgings." In any case there can be no doubt that the genius of Newton cast its light on Hales, as Sachs has clearly pointed out

1 In 1699 Newton was made Master of the Mint and appointed Whiston his deputy in the Lucasian Professorship, an office he finally resigned in I 703 (Brewster's Life of Newton, I831, p. 249). 2 " There, if anywhere, his dear shade must linger," Trevelyan, Life and Letters of Lord Macaulay (I volume edit. I88I, p. 55). 
(Hist. Bot., Eng. Tr., p. 477). Another great man influenced Hales, namely Robert Boyle, who was born 1627 and died 169r. John Mayow again, that brilliant son of Oxford, whose premature death at 39 in 1679 was so heavy a blow to science, belongs to the same school as Hales-the school which was within an ace of founding a rational chemistry, but which was separated from the more obvious founders of that science by the phlogistontheory of Becchers and Stahl. I do not find any evidence that Hales was influenced by the phlogistic writers, and this is comprehensible enough, if, as I think, he belongs to the school of Mayow and Boyle.

The later discoverers in chemistry are of the following dates, Black 1728-1799, Cavendish $1731-1810$, Priestley 1733-1804, Scheele 17421786, Lavoisier 1743, guillotined 1794. These were all born about the time of Hales' zenith, nor did he live ${ }^{1}$ to see the great results they accomplished. But it should not be forgotten that Hales' chemical work made more easy the triumphant road they trod.

I have spoken of Hales in relation to chemists and physicists because, though essentially a physiologist, he seems to me to have been a chemist and physicist who turned his knowledge to the study of life, rather than a physiologist who had some chemical knowledge.

Whewell points out in his History of the Inductive

${ }^{2}$ Black's discovery of $\mathrm{CO}_{2}$, however, was published in 1754 , seven years before Hales died, but Priestley's, Cavendish's and Lavoisier's work on $O$ and $H$ was later. 
Sciences ${ }^{1}$ that the iphysiologist asks questions of Nature in a sense differing from that of the physicist.. The Why? of the physicist meant Through what causes? that of the physiologist-to what end? This distinction no longer holds good, and if it is to be applied to Hales it is a test which shows him to be a physicist. For, as Sachs shows, though Hales was necessarily a teleologist in the theological sense, he always asked for purely mechanical explanations. He was the most unvitalistic of physiologists, and I think his explanations suffered from this cause. For instance, he seems to have held that to compare the effect of heat on a growing root to the action of the same cause on a thermometer ${ }^{2}$ was a quite satisfactory proceeding. And there are many other passages in Vegetable Staticks where one feels that his speculations are too heavy for his knowledge.

Something must be said of Hales' relation to his predecessors and successors in botanical work. The most striking of his immediate predecessors were Malpighi 1628-I694, Grew 1628-i711, Ray 1627-I705, and Mariotte (birth unknown, died 1684); and of these the three first were born one hundred years before the publication of Vegetable Staticks. Malpighi and Grew were essentially plant-anatomists, though both dealt in physiological speculations. Their works were known to Hales, but they do not seem to have influenced him. We have seen that as a chemist Hales is some-

1837 , irr. p. $3^{89}$.

Vegetable Staticks, p. 346. 
what of a solitary figure, standing between what may be called the periods of Boyle and of Cavendish. This is even more striking in his botanical position, for here he stands in the solitude of all great original inquirers. We must go back to Van Helmont, $1577-1644$, to find anyone comparable to him as an experimentalist. His successors have discovered much that was hidden from him, but consciously or unconsciously they have all learned from him the true method and spirit of physiological work.

It may be urged that in exalting Hales I am unfair to Malpighi. It may be fairer to follow Sachs in linking these great men together, and to insist on the wonderful fact that before Malpighi's book in 1671, vegetable physiology was still where Aristotle left it, whereas 56 years later, in 1727 , we find in Hales' book an experimental science in the modern sense.

It should not be forgotten that students of animal physiology agree with botanists as to Hales' greatness. A writer in the Encyclopodia Britannica speaks of him as "the true founder of the modern experimental method in physiology."

According to Sachs, Ray made some interesting observations on the transmission of water, but on the whole what he says on this subject is not important. There is no evidence that Ray influenced Hales.

Mariotte, the physicist, came to one physiological conclusion of great weight ${ }^{1}$; namely, that

${ }^{1}$ Sachs, Geschichte, p. 502. Malpighi held similar views. 
the different qualities of plants, e.g. taste, odour, etc., do not depend on the absorption from the soil of differently scented or flavoured principles, as the Aristotelians imagined, but on specific differences in the way in which different plants deal with identical food material-an idea which is at the root of a sane physiological outlook. These views were published in $1679,{ }^{1}$ and may have been known to Hales. He certainly was interested in such ideas, as is indicated-by his attempts to give flavour to fruit by supplying them with medicated fluids. He probably did not expect success, for he remarks (p. 360): "The specifick differences of vegetables, which are all sustained and grow from the same nourishment, is [sic] doubtless owing to the very different formation of their minute vessels, whereby an almost infinite variety of combinations of the common principles of vegetables is made." $\mathrm{He}$ continues in the following delightful passage : "And could our eyes attain to a sight of the admirable texture of the parts on which the specific differences in plants depends, [sic] what an amazing and beautiful scene of inimitable embroidery should we behold? what a variety of masterly strokes of machinery? what evident marks of consummate wisdom should we be entertained with?" To conclude what has been said on Hales' chronological positionIngenhousz, the chief founder of the modern point of view on plant nutrition, was born 1730 and published his book, On Vegetables, etc., in 1779.

1 Sachs, Geschichte, p. 499. 
So that what was said of Hales' chemical position is again true of him considered in relation to nutrition; he did not live to see the great discoveries made at the close of the I 8 th century.

There is in his writing a limpid truthfulness and simplicity, unconsciously decorated with pretty 18 th century words and half-rusticities which give it a perennial charm. And inasmuch as I desire to represent Hales, not only as a man to be respected but also to be loved, it will be as well to give what is known of the personal side of his character before going on to a detailed account of his work.

He was, as we have seen, entered at Corpus Christi College, Cambridge, in June 1696. In February $1702-3$ he was admitted a fellow of the College. It was during his life as a fellow that he began to work at chemistry in what he calls "the elaboratory in Trinity College." The room is now occupied by the Senior Bursar, and forms part of the beautiful range of buildings in the bowling green, which, freed from stucco and other desecration, are made visible in their ancient guise by the piety of a son of Trinity and the wisdom of the College authorities. It was here, according to Dr. Bentley, that "the thieving Bursars of the old set embezzled the College-timber,"1 and it was this room that was fitted up as "an elegant laboratory" in 1706 for John Francis Vigani, an Italian chemist, who had taught unofficially in the

${ }^{1}$ Quoted by Carōe, in his paper read before the Cambridge Archaeological Society on King's Hosiel, etc., and "Printed for the Master and Fellows of Trinity College," in I 909. 
University for some years, and became, in 1703 , the first Professor of Chemistry at Cambridge.

Judging from his book, Medulla Chymiae, 1682, Vigani was an eminently practical person, who cared greatly about the proper make of a furnace and the form of a retort but was not cumbered with theories.

Hales vacated his fellowship and became minister or perpetual curate of Teddington ${ }^{1}$ in 1 708-9, and there he lived until his death, fiftytwo years afterwards. He was married (? 1719) and his wife died without issue in $172 \mathrm{r}$.

$\mathrm{He}$ attracted the attention of Royalty, and received plants from the King's garden at Hampton Court. Frederick Prince of Wales, the father of George III., is said to have been fond of surprising him in his laboratory at Teddington. This must surely be a unique habit in a prince, but we may remember that, in the words of the Prince's mock epitaph, "Since it is only Fred there's no more to be said." He became Clerk of the Closet to the Dowager Princess, and this "mother of the best of Kings," as she calls herself, put up his monument in Westminster Abbey. Hales had the honour of receiving the Copley Medal from the Royal Society in 1739 , and Oxford made him a D.D. in 1733.

Some years ago I made a pilgrimage to Teddington, and found in the parish registers many interesting entries by his hand; the last, in a tremulous writing, is on November 4th, I760, two months before he died. He was clearly an active parish

$1 \mathrm{He}$ also held the living of Farringdon in Hampshire where he occasionally resided. 
priest. He made his female parishioners do public penance when he thought they deserved it. He did much for the fabric of the church. "In $1754^{1}$ he helped the parish to a decent water supply and characteristically records in the parish register that the outflow was such as to fill a two-quart vessel in 'three swings of a pendulum beating seconds, which pendulum was $39+\frac{2}{10}$ inches long from the suspending nail to the middle of the plumbet or bob.'" Under the tower he helped to build (which now serves as a porch) Stephen Hales is buried, and the stone which covers his body is being worn away by the feet of the faithful. By the piety of a few botanists a mural tablet, on which the epitaph is restored, has been placed near the grave.

Horace Walpole called Hales "a poor, good, primitive creature" and $\mathrm{Pope}^{2}$ (who was his neighbour) said, "I shall be very glad to see Dr. Hales, and always love to see him, he is so worthy and good a man." Peter Collinson writes of "his constant serenity and cheerfulness of mind"; it is also recorded that "he could look even upon wicked men, and those who did him unkind offices, without any emotion of particular indignation; not from want of discernment or sensibility, but he used to consider them only like those experiments which, upon trial, he found could never be applied to any useful purpose, and which he therefore calmly and dispassionately laid aside."

1 Dict. Nat. Biog.

2 With a certain idleness Pope reduces him to plain Parson Hale, for the sake ot a rhyme in the Epistle to Martha Blount, I, I98. 
Hales' work may be divided into three heads : I Physiological, animal and vegetable;

II Chemical ;

III Inventions and miscellaneous essays.

Under No. I I shall deal only with his work on plants. The last heading (No. III) I shall only refer to slightly, but the variety and ingenuity of his miscellaneous publications is perhaps worth mention here as an indication of the quality of his mind. It seems to me to have had something in common with the versatile ingenuity of Erasmus Darwin and of his grandson Francis Galton. The miscellaneous work also exhibits Hales as a philanthropist, who cared passionately for bettering the health and comfort of his fellow creatures by improving their conditions of life.

His chief book from the physiological and chemical point of view is his Vegetable Staticks. It will be convenient to begin with the physiological part of this book, and refer to the chemistry later. $V$ egetable Staticks is a small $8 \mathrm{vo}$ of 376 pages, dated on the title-page I727. The "Imprimatur Isaac Newton Pr. Reg. Soc." is dated February 16, 1720, and this date is of some slight interest, for Newton died on March 20, and Vegetable Staticks must have been one of the last books he signed.

The dedication is to George Prince of Wales, afterwards George III. The author cannot quite avoid the style of his day, for instance: "And as Solomon the greatest and wisest of men, disdeigned ${ }^{1}$ not to inquire into the nature of Plants, from the

1 The original reads "deigned not," an obvious slip. 
Cedar of Lebanon, to the Hyssop that springeil out of the wall: So it will not, I presume, be an unacceptable entertainment to your Royal Highness," etc.

But the real interest of the dedication is its clear statement of his views on the nutrition of plants. $\mathrm{He}$ asserts that plants obtain nourishment, not only from the earth, "but also more sublimed and exalted food from the-air, that wonderful-fluid, which is of such importance to the life of Vegetables and Animals," etc. We shall see that his later statement is not so definite, and it is well to rescue this downright assertion from oblivion.

His book begins with the research for which he is best known, namely that on transpiration. He took a sunflower growing in a flower-pot, covering the surface of the earth with a plate of thin milled lead, and cemented it so that no vapour could pass, leaving a corked hole to allow of the plant being watered. He did not take steps to prevent loss through the pot, but at the end of the experiment cut off the plant, cemented the stump, and found that the "unglazed porous pot" perspired 2 ozs. in 12 hours, and for this he made due allowance.

The plant so prepared he proceeded to weigh at stated intervals. He obtained the area of the leaves by dividing them into parcels according to their several sizes, and measuring one leaf ${ }^{1}$ of each parcel. The loss of water in 12 hours converted to the metric system is 1.3 c.c. per 100 sq. $\mathrm{cm}$. of

1 This he does by means of a network of threads 1 inch apart. Pfeffer, Pflanzenphysiologie, ed. I, I. p. 142, recommends the method and gives Hales as his authority. 
leaf-surface; and this is of the same order of magnitude as Sachs' result, ${ }^{1}$ namely, 2.2 c.c. per $100 \mathrm{sq} . \mathrm{cm}$.

He goes on to measure the surface of the roots ${ }^{2}$ and to estimate the rate of absorption per area. The calculation is of no value, since he did not know how small a part of the roots is absorbent, nor how enormously the surface of that part is increased by the presence of root-hairs. He goes on to estimate the rate of the flow of water up the stem; this would be 34 cubic inches in 12 hours if the stem (which was one square inch in section) were a hollow tube. He then allowed a sunflower stem to wither and to become completely dry, and found that it had lost $\frac{3}{4}$ of its weight, and assuming that the $\frac{1}{4}$ of the "solid parts" left was useless for the transmission of water he increases his 34 by $\frac{1}{3}$ and gives $45 \frac{1}{3}$ cubic inches in 12 hours as the rate. But the solid matter which he neglected contained the vessels, and he would have been nearer to the truth had he corrected his figures on this basis. The simplest plan is to compare his results with those obtained by $\mathrm{Sachs}^{3}$ in allowing plants to absorb solutions of lithium-salts. If the flow takes place through conduits equivalent to a quarter of a square inch in area, the fluid will rise in 12 hours to a height of $4+34$ or 136 inches, or in one hour to $28.3 \mathrm{~cm} .^{4}$ This is a result comparable to, though

1 Pflanzenphysiologie, 1865 (Fr. Trans. 1868), p. 254.

${ }^{2}$ He gives it as 15.8 square inches, the only instance $I$ have come across of his use of decimals.

3 Arbeiten, 11. p. 182.

'See Sachs' Pflanzenphys. 1865 (Fr. Trans. 1868), p. 257, where the above correction is applied to Hales' work. 
very much smaller than, Sachs' result with the sunflower, viz. $63 \mathrm{~cm}$. per hour.

The data are however hardly worth treating in this manner. But it is of historic interest to note that when Sachs was at work on his Pflanzenphysiologie, published in 1865 , he was compelled to go back nearly 140 years to find any results with which he could compare his own.

We need not follow Hales into his comparison between the "perspiration" of the sunflower and that of a man, nor into his other transpiration experiments on the cabbage, vine, apple, etc. But one or two points must be noted. He found ${ }^{1}$ the "middle rate of perspiration" of a sunflower in I 2 hours of daylight to be 20 ounces, and that of a "dry warm night" about 3 ounces; thus the day transpiration was roughly seven times the nocturnal rate. This difference may be accounted for by the closure of the stomata at night, a phenomenon unknown to Hales.

Hales $^{2}$ notes another point which a knowledge of stomatal behaviour might have explained, viz., that with "scanty watering the perspiration much abated "; he does not attempt an explanation, but merely refers to it as a "healthy latitude of perspiration in this sunflower."

In the course of his work on sunflowers he notices that the flower follows the sun. He says, however that it is "not by turning round with the sun," i.e. that it is not a twisting of the stalk, and

1 Vegetable Staticks, p. 5.

${ }^{2}$ Ibid., p. 14. 
goes on to call it nutation, which must be the locus classicus for the term used in this sense.

An experiment ${ }^{1}$ that I do not remember to have seen quoted elsewhere is worth describing. It is incidentally of interest as showing the generous scale on which his work was planned. An apple bough five feet long was fixed to a vertical glass tube nine feet long. The tube being above and the branch hanging below, the pressure of the column of water would act in concert with the suck of the transpiring leaves, instead of in opposition to this force. He then cut the bare stem of his branch in two, placing the apical half of the specimen (bearing side branches and leaves) with its cut end in a glass vessel of water; the basal and leafless half of the branch remained attached to the vertical tube of water. In the next 30 hours only 6 ounces dripped through the leafless branch, whereas the leafy branch absorbed 18 ounces. This, as he says, shows the great power of perspiration. And though he does not pursue the experiment, it is worthy of note as an attempt, like those of Janse ${ }^{2}$ and others, to correlate the flow of water under pressure with the flow due to transpiration.

It is interesting to find that Hales used the three methods of estimating transpiration which have been employed in modern times-namely, weighing, (ii) a rough sort of potometer, (iii) enclosing a branch in a glass balloon and collecting

1 Vegetable Staticks, p. 4I.

${ }^{2}$ Janse in Pringsheim's Jahrb. xvirr. p. 38. The later literature is given by Dixon in Progressus Rei Bot. III., 1909, p. $5^{8}$. 
the precipitated moisture, the well-known plan followed by various French observers.

He (Vegetable Staticks, p. 5I) concluded his balance of loss and gain in transpiring plants by estimating the amount of available water in the soil to a depth of three feet, and calculating how long his sunflower would exist without watering. He further concludes (p. 57) that an annual rainfall of 22 inches is "sufficient for all the purposes of nature, in such flat countries as this about Teddington."

He constantly notes small points of interest, e.g. (p. 82) that with cut branches the water absorbed diminishes each day, and that the former vigour of absorption may be partly renewed by cut tina fresh surface. ${ }^{1}$

He also showed (p. 89) that the transpiration current can flow perfectly well from apex to base when the apical end is immersed in water.

These are familiar facts to us, but we should realise that it is to the industry and ingenuity of Hales that we owe them. In a repetition (p. 90) of the last experiment we have the first mention of a fact fundamentally important. He took two branches (which with a clerical touch he calls $M$ and $N$ ), and having removed the bark from a part of the branch, dipped the ends in water, $N$ with the great end downwards but $M$ upside down. In this way he showed that the bark was not necessary for the absorption or transmission of water. ${ }^{2}$ I suspect

1 Compare F. von Höhnel, Bot. Zeitung, 1879, p. 318.

${ }^{2}$ This is also shown by experiment xc, Vegetable Staticks, p. I23. 
that one branch was inverted out of respect for the hypothesis of sap-circulation. He perhaps thought that water could travel apically by the wood, but only by the bark in the opposite direction.

Next in order (p. 95) comes his well-known experiment on the pressure exerted by peas increasing in size as they imbibe water. There are, however, pitfalls in this result of which Hales was unaware, and perhaps the chief interest to us now is that he considered the imbibition of the peas ${ }^{1}$ to be the same order of phenomenon as the absorption of water by a cut branch-notwithstanding the fact that he knew the absorption to depend largely on the leaves. ${ }^{2}$ It may be noticed that Sachs, in his imbibitional view of water-transport, may be counted a follower of Hales.

In order to ascertain "whether there was any lateral communication of the sap and sap vessels, as there is of blood in animals," Hales (p. I 2 I) made the experiment which has been repeated in modern laboratories, i.e. cutting a "gap to the pith," and another opposite to it and a few inches above. This he did on an oak branch six feet long whose basal end was placed in water. The branch continued to "perspire" for two days, but gave off only about half the amount of water transpired by a normal branch. ${ }^{4}$ He does not trouble himself about

1 The method by which Hales proposed to record the depth of the sea is a variant of this apparatus.

2 Vegetable Staticks, p. 92.

According to Sachs (Geschichte, p. 509) Ray employed this method.

"Other facts showed that the "gapped" branches did not behave quite normally. 
this difference, being satisfied of "great quantities of liquor having passed laterally by the gap."

$\mathrm{He}$ is interested in the fact of lateral transmission in connexion with the experiment of the suspended tree (Fig. 24, p. 126), which is dependent on the neighbours to which it is grafted for its water supply. This seems to be one of the results that convinced him that there is a distribution of food material which cannot be described as circulation of sap in the sense that was then in vogue.

Hales (p. 143) was one of the first ${ }^{1}$ to make the well-known experiment - the removal of a ring of bark, with the result that the edge of bark nearest the base of the branch swells and thickens in a characteristic manner. He points out that if a number of rings are made one above the other, the swelling is seen at the lower edge of each isolated piece of bark, and therefore (p. 143) the swelling must be attributed "to some other cause than the stoppage of the sap in its return downwards," because the first gap in the bark should be sufficient to check the whole of the flowing sap. ${ }^{2}$ He must, in fact have seen that there is a redistribution of plastic material in each section of bark.

We now for the moment leave the subject of transpiration and pass on to that of root-pressure on which Hales is equally illuminating.

${ }^{1}$ He refers (p. I4 I) to what is in principle the same experiment (see Fig. 27) as due to Mr. Brotherton, and published in the Abridgement of the Phil. Trans. II. p. 708.

2 He notices that the swelling of the bark is connected with the presence of buds. The only ring of bark which had no bud showed no swelling. 
His first experiment (Vegetable Staticks, p. 100), was with a vine, to which he attached a vertical pipe made of three lengths of glass-tubing jointed together. His method is worth notice. $\mathrm{He}$ attached the stump to the manometer with a "stiff cement made of melted Beeswax and Turpentine, and bound it over with several folds of wet bladder and pack-thread." We cannot wonder that the making of water-tight connexions was a great difficulty, and we can sympathise with his belief that he could have got a column more than 2 I feet high but for the leaking of the joints on several occasions. He notes the familiar fact that the vine-stump absorbed water before it began to extrude it.

He afterwards (pp. 106-7) used a mercury gauge, and registered a root-pressure of $32 \frac{1}{2}$ inches or 36 feet $5 \frac{1}{3}$ inches of water, which he proceeds to compare with his own determination of the bloodpressure of the horse ( $8 \mathrm{feet}$ ) and of other animals. Perhaps the most interesting of his root-pressure experiments was that (p. I10) in which several manometers were attached to the branches of a bleeding vine, and showed a result which convinced him that "the force is not from the root only, but must proceed from some power in the stem and branches," a conclusion which some modern workers have also arrived at.

\section{Assimilation.}

Hales' belief that plants draw part of their food from the air, and again, that air is the breath of life, of vegetables as well as of animals (p. 148), are 
based upon a series of chemical experiments performed by himself. Not being satisfied with what he knew of the relation between "air" (by which he meant gas) and the solid bodies in which he supposed gases to be fixed, he delayed the publication of Vegetable Staticks for some two years, and carried out the series of observations which are mentioned in his title-page as "An attempt to analyse the air, by a great variety of chymiostatical experiments," occupying 162 pages of his book. ${ }^{1}$

The theme of his inquiry he takes (Vegetable Staticks, p. 165) from "the illustrious Sir Isaac Neruton," who believed that "dense bodies by fermentation rarify into several sorts of Air ; and this Air by fermentation, and sometimes without it, returns into dense bodies."

Hales' method consisted in heating a variety of substances, e.g. wheat-grains, pease, wood, hog's blood, fallow-deer's horn, oyster-shells, red-lead, gold, etc., and measuring the "air" given off from them. He also tried the effect of acid on iron filings, oyster-shells, etc. In the true spirit of experiment hé began by strongly heating his retorts (one of which was a musket barrel) to make sure that no air arose from them. It is not evident to me why he continued at this subject so long. He had no means of distinguishing one gas from another, and almost the only quality noted is a want of permanence, e.g. when the $\mathrm{CO}_{2}$ produced

${ }^{1}$ It appears that Mayow made similar experiments. Dict. Nat. Biog. s.v. Mayow. 
was dissolved by the water over which he collected it. Sir E. Thorpe ${ }^{1}$ points out that Hales must have prepared hydrogen, carbonic acid, carbonic oxide, sulphur dioxide, and marsh gas. It may, I think, be said that Hales deserved the title usually given to Priestley, viz. "the father of pneumatic ${ }^{2}$ chemistry."

Perhaps the most interesting experiment made by Hales is the heating of minium (red-lead) with the production of oxygen. It proves that he knew, as Boyle, Hooke and Mayow did before him, that a body gains weight in oxidation. Thus Hales remarks : "That the sulphurous and aereal particles of the fire are lodged in many of those bodies which it acts upon, and thereby considerably augments their weight, is very evident in Minium or Red Lead, which is observed to increase in weight in undergoing the action of the fire. The acquired redness of the Minium indicating the addition of plenty of sulphur in the operation." He also speaks of the gas distilled from minium, and remarks: "It was doubtless this quantity of air in the Minium which burst the hermetically sealed glasses of the excellent $M r$. Boyle, when he heated the Minium contained in them by a burning glass" (p. 287).

This was the method also used by Priestley in his celebrated experiment of heating red-lead in hydrogen, whereby the metallic lead reappears

${ }^{1}$ History of Chemistry, 1909, I. p. 69.

${ }^{2}$ Hales made use of a rough pneumatic trough, the invention of which is usually ascribed to Priestley (Thorpe's History of Chemisiry, I. p. 79). 
and the hydrogen disappears by combining with the oxygen set free. This was expressed in the language of the day as the reconstruction of metallic lead by the addition of phlogiston (the hydrogen) to the calx of lead (minium). Thorpe points out the magnitude of the discovery that Priestley missed, and it may be said that Hales too was on the track, and had he known as much as Priestley it would not have been phlogiston that kept him from becoming a Cavendish or Lavoisier. What chiefly concerns us, however, is the bearing of Hales' chemical work on his theories of nutrition. $\mathrm{He}$ concludes that "air makes a very considerable part of the substance of Vegetables," and goes on to say (p. 2I I) that "many of these particles of air" are "in a fixt state, strongly adhering to and wrought into the substance of " plants. ${ }^{1}$ He has some idea of the instability of complex substances, and of the importance of the fact, for he says ${ }^{2}$ that "if all the parts of matter were only endued with a strongly attracting power, [the] whole [of] nature would then become one unactive cohering lump." This may remind us of Herbert Spencer's words : "Thus the essential characteristic of living organic matter, is that it unites this large quantity of contained motion with a degree of cohesion that permits temporary fixity of arrangement " (First Principles, § 103). With regard to the way in which plants absorb and fix the "air" which he finds in their

1 He speaks here merely of the apples used in a certain experiment, but it is clear that he applies the conclusion to other plants.

${ }^{2}$ Vegetable Staticks, p. 313. It should be noted that Hales speaks of organic as well as inorganic substances. 
tissues, Hales is not clear; he does not in any way distinguish between respiration and assimilation. But as I have already said, he definitely asserts that plants draw "sublimed and exalted food" from the air.

As regards the action of light on plants, he suggests (p. 327) that "by freely entering the expanded surfaces of leaves and flowers" light may "contribute much to the ennobling principles of vegetation." He goes on to quote Newton (Opticks, query 30): "The change of bodies into light, and of light into bodies, is-very conformable to the course of nature, which seems delighted with transformations." It is/ a problem for the antiquary to determine, whether or no Swift took from Newton the idea of bottling and recapturing sunshine as practised by the philosopher of Lagado. He could hardly have got it from Hales, since Gulliver's Travels was published in 1726, before Vegetable Staticks.

Nevertheless, Hales is not quite consistent about the action of light; thus (p. 351) he speaks of the dull light in a closely planted wood as checking the perspiration of the lower branches, so that "drawing little nourishment, they perish." This is doubtless one effect of bad illumination under the abovenamed conditions, but the check to photosynthesis is a more serious result. In his final remarks on vegetation ( $p$. 375) Hales says in relation to greenhouses, "It is certainly of as great importance to the life of the plants to discharge that infected rancid air by the admission of fresh, as it is to defend them from the extream cold of the outward air." This idea of ventilating greenhouses he carried out in a 
plant-house designed by him for the Dowager Princess of Wales, in which warm fresh air was admitted. The house in question was built in 1761 in the Princess's garden at Kew, which afterwards became what we now know as Kew Gardens. The site of Hales' greenhouse, which was only pulled down in 1861 , is marked by a big wistaria which formerly grew on the greenhouse wall. It should be recorded that Sir W. Thiselton-Dyer ${ }^{1}$ planned a similar arrangement independently of Hales, and found it produced a marked improvement of the well-being of the plants.

It is worthy of note, -that-though-Hales must have known Malpighi's theory of the function of leaves (which-was broadly-speaking the same as his own), he does not as far-as-I know-refer to it. In his preface (p. ii.) he regrets that Malpighi and Grew, whose anatomical knowledge he appreciated, had not "fortuned to have fallen into this statical" way of inquiry." I believe he means an inquiry of an experimental nature, and I think it was because Malpighi's theory was dependent on analogy rather than on ascertained facts that it influenced Hales so little.

There is another part of physiology on which Hales threw light. He was the first, I believe, to investigate the distribution of growth in developing

1 The above account of Hales' connexion with the Royal Gardens at Kew is from the Kew Bulletin, 1891, p. 289 .

' I am indebted to Sir E. Thorpe for a definition of statical. "Statical (Med.) noting the physical phenomena presented by organised bodies in contradiction to the organic or vital." (Worcester's Diclionary. 1889.), 
shoots and growing leaves, by marking them and measuring the distance between the marks after an interval of time. He describes (p. 330) and figures (p. 344) with his usual thoroughness the apparatus employed; this was a comb-like object made by fixing into a handle five pins $\$$ inch apart from one another ; the points being dipped in red-lead and oil, a young vine-shoot was marked with ten dots $\frac{1}{4}$ inch apart. In the autumn he examined his specimen, and finds that the youngest internode or "joynt" had grown most, and the basal part having been "almost hardened" when he marked it, had "extended very little." In this-a tentative experiment-he made the mistake of not re-measuring his plants at short intervals of time, but it was an admirable beginning, and the direct ancestor of Sachs'1 great research on the subject. In his discussion on growth it is interesting to find the idea of turgescence supplying the motive force for extension. This conception he takes from Borelli. ${ }^{2}$

Hales sees in the nodes of plants "plinths or abutments for the dilating pith to exert its force on" (p. 335) ; but he acutely foresees a modern objection $^{3}$ to the explanation of growth as regulated solely by the hydrostatic pressure in the cell. Hales says (p. 335) : "But a dilating spongy substance, by equally expanding itself every way, would not

\section{Arbeiten, I.}

2 Borelli, De Motu Animalitu, Pt. Ir. Ch. xiii. According to Sachs, Ges. d. Botanik, p. 582, Mariotte (1679) had suggested the same idea.

'Nägeli, Starkekörner, p. 279. 
produce an oblong shoot but rather a globose one."

It is not my place to speak of Hales' work in animal physiology, nor of those researches bearing on the welfare of the human race which occupied his later years. Thus he wrote against the habit of drinking spirits, and made experiments on ventilation by which he benefited English and French prisons, and even the House of Commons; then too he was occupied in attempts to improve the method of distilling potable water at sea, and of preserving meat and biscuit on long voyages. ${ }^{1}$

We are concerned with him simply as-a-vegetable physiologist,-and in that character his fame is imperishable. Of the book which I have been using as my text, namely, Vegetable.Staticks, Sachs says: "It was the first comprehensive work the world had seen which was devoted to the nutrition of plants and the movement of their sap.... Hales had the art of making plants reveal themselves. By experiments carefully planned and cunningly carried out he forced them to betray the energies hidden in their apparently inactive bodies," 2 These words, spoken by a great physiologist of our day, form a fitting tribute to one who is justly described as the father of physiology.

1 See his Philosophical Experiments, 1739.

'Geschichte d. Botanik, p. 515 (free translation). 


\section{NULLIUS IN VERBA 1}

There is a well-known story of Charles Darwin which I shall venture to repeat, because nothing can better emphasise the contrast between Shrewsbury School as it is and as it was.

Charles Darwin used, as a boy, to work at chemistry in a rough laboratory fitted up in the tool-house at his home in Shrewsbury. The fact that he did so became known to his school-fellows, and he was nicknamed "Gas." I have an old Delphine Virgil of my father's in which this word is scrawled, together with the name Miss Case, no doubt a sneer at his having come from Case's preparatory school. Dr. Butler, the Head Master, heard of the chemical work, and Charles Darwin was once publicly rebuked by that alarming person for wasting his time on such useless subjects. My father adds, "He called me very unjustly a poco curante, and as I did not understand what he meant it seemed to me a fearful reproach." A poco curante means of course "a don't-care person"? one who takes no interest in things, and might perhaps be translated by "slacker." I do not suppose that Dr. Butler is likely ever to be forgotten, but as it is, he is sure of a reasonable

1 An Address on the occasion of the opening of the Darwin Laboratories at Shrewsbury School, October 20, I9II. 
share of immortality as the author of a description so magnificently inappropriate. ${ }^{1}$

This is the contrast I referred to ; on one hand a Head Master in 1822 doing his best to discourage a boy from acquiring knowledge of a great subject in the best possible way, i.e. by experiment. And on the other, a Head Master of the same school in I 9 I I encouraging, with a wise zeal, the rational study of science as a regular part of the school course. It may not be possible to trace out the complete evolution of these Darwin Buildings, but I like to fancy that the germ from which they have sprung is that tool house at the Mount. ${ }^{2}$

It is some comfort to us to know that Shrewsbury was not the only place which failed to educate my father in the regulation lines. When he left school he went to Edinburgh University to study

${ }^{1}$ In the Life and Letters of Charles Darwin, Vol. 1., are given my father's autobiographical recollections. He wrote (pp. 3 I 32): "Nothing could have been worse for the development of my mind than Dr. Butler's school, as it was strictly classical, nothing else being tanght, except a little ancient geography and history." This seems to be an exaggeration, as the following list shows. It is taken from Samuel Butler's Life and Letters of Dr. Samuel Butler, 1896, Vol 1., p. I96. The "weekly course of instruction for the fifth and sixth forms, under Dr. Butler," is given, and the items which are not classical are as follows :-

Monday.-English History follows Grecian and Roman history.

The rest of a very full day is classical.

Tuesday.-Half-holiday. All classical except that the Masters of accomplishments attend in the efternoon.

Wednesday. - All classical.

Thursday.-Half-holiday. All classical except a " Lecture in algebra" for the sixth and upper fifth forms.

Friday.-All classical.

Saturday.-All classical except " Lecture in Euclid to sixth and upper fifth."

2 Charles Darwin's home at Shrewsbury. 
medicine. But he found anatomy and materia medica intolerable, and the operating theatre was a horror. So he began to work at science in his own way. He learned to stuff birds from an old negro who had known Waterton. Of this instructor he says, "I used often to sit with him, for he was a very pleasant and intelligent man." $\mathrm{He}$ also caught sea beasts in the pools on the shore, and made one or two small observations, which were communicated to the Plinian Society.

Then he was sent to Cambridge with a view to taking Orders. He enjoyed himself riding and shooting, and especially in catching beetles in the fens. But also in more intellectual ways, as in listening to the anthem in King's Chapel, and looking at the pictures in the Fitzwilliam Museum. Henslow, the Professor of Botany treated him as a friend rather than as a pupil, and finally settled his career by sending him round the world in H.M.S. Beagle. He entered the ship an undergraduate, and left it after five years a man of science. I give these well known details to show how little he profited by any regular course of study either at Shrewsbury, Edinburgh, or Cambridge. His start in life depended on the recognition of his capacity by Henslow, and was nearly wrecked by FitzRoy, the Captain of the Beagle, suspecting that no one with a nose like my father's could be an energetic person.

Are we therefore to conclude that the best method of scientific education is to force a boy to work at uncongenial subjects? In the case of a genius it may not much matter what he is taught; 
he will succeed, in spite of his education. But for us lesser mortals it does matter. I am not going to talk about the way in which science should be taught in schools, a matter about which I am not competent to speak. What I shall speak of is the learning rather than teaching of the subject.

I once heard Lord Rayleigh refer to the necessity of putting one's subject-matter clearly before an audience, and he illustrated his point by the following story. Somebody, possibly a lady, came from listening to a lecture by Mr. So-and-So, and when asked what it was about, replied, "He didn't say." I shall follow Lord Rayleigh's advice and tell you that my subject is "Why science should be learned." Why it is worth while for a boy to give up some of his time to this particular form of knowledge, and what advantage he may expect to gain from so doing.

There are many possible reasons for a boy's learning science.

I Because he is told to. This is an excellent reason, but not inspiriting.

II To gét marks in an Entrance Scholarship examination. This is a virtuous reason but not intellectual.

III To gain knowledge which will be of use when he comes to follow a profession, and wants to know physics in view of becoming an engineer, or physiology as a part of medical training. This is a worthy reason, but not a common one. 
IV Lastly, a boy may learn science because he wants to ; because he finds it entertaining; because it satisfies an unreasoning desire to know how things in general work.

This is the best possible reason and the most efficient, and what I propose, is to inquire whether this wish to know something of science can be justified.

The word 'science' simply means knowledge, but it is usually applied to knowledge that can be verified. Thus we learn by heart that Queen Anne died in I 7 I4. I believe this to be a fact, but I have no means of verifying it. But if I am told that putting chalk into acid will produce a heavy gas having the quality of extinguishing a lighted match, I can verify it. I can do the thing and see the results. I am now the equal of my teacher; I know it in the same way that he does. It has become my very own fact, and it seems to have the satisfactory quality that possession gives. This characteristic of scientific knowledge is not always recognised. I mean the profound difference between what we know and what we are told. When science began to flourish at Cambridge in the 'seventies, and the University was asked to supply money for buildings, an eminent person objected and said, "What do they want with their laboratories? - why can't they believe their teachers, who are in most cases clergymen of the Church of England?" This person had no conception of what the word 'knowledge' means as understood in science. 
Another characteristic of science is that it makes us able to predict. I have already referred to the fact that Queen Anne is dead, and we know, or are told, that she died, as I said before, in 1714 ; we also know that George I. died in 1727, and George II. in 1760 , but that would not enable us to predict that George III. would die in 1820 . They are isolated facts not connected by the causal bond that knits together a series of scientific truths. And this is after all a fortunate thing for the peace of mind of reigning sovereigns.

It is said that you should never prophesy unless you know. But science is made up of prophecies. Some are famous, like the prediction of Adams and Leverrier that a new planet would be found in a stated position. Some are on a humbler scale, such as my father's prediction that a big moth would be found to carry the pollen of Hedychium by brushing it off with the tips of its hovering wings, a method of fertilisation unheard of at the time, which however proved to be the fact.

You may say that it does not matter whether the moth does this particular thing or not. This is no doubt true from a strictly commercial point of view. But in science all facts have some value. We should cultivate a point of view about facts the very reverse of that of the unknown person who said that all books are rather dull.

I once heard a celebrated physicist describe how he explained to an American business man an elaborate spectroscope for examining the sun. The American asked what good it was. The physicist explained that with it you can discover whether or 
no sodium exists in the sun. The American was silent for some time, and then said, "But who the 'nation cares whether there is sodium in the sun or not?" He had not the scientific spirit which does care about sodium in the sun.

Scientific discovery is, as I said, made up of a series of prophecies. You observe fact No. 1, and you say if this be so No. 2 ought to be true, and on examination you find this is true, and No. 2 suggests No. 3. Or else you find 2 not to be true ; this makes you suspect your original fact, and on carefully going over your observation you find No. I was a mistaken observation. The successful man of science is one to whom familiar objects suggest those prophecies generally known as theories. My father was remarkable for not letting what seem to be trifling facts pass without suggesting to him a theory. The flies that are caught on the sundew must have been seen by innumerable people-but it remained for him to prove the truth of his guess that some plants possess digestive ferments like our own, and live on the insects they catch and digest.

The art of being guided by slight indications is sometimes called the method of Zadig, which I learn from Mr. Huxley's essay and not from Voltaire. Mr. Huxley points out that it is not only possible thus to prophecy what will happen, butalso to determine what has happened; and he suggests that there should be a word 'backtell' as well as foretell. Zadig, who was an oriental philosopher, met one day the King's servants in great trouble about the loss of their master's favourite horse. 
When asked whether he had seen it he said, "A fine galloper, is it not? small hoofed, five feet high, tail $3 \frac{1}{2}$ feet long. Cheek-pieces of the bit 23-carat gold, shoes silver." They of course begged to know where it was, and he said he had not seen it.

This will be recognised as the method of Sherlock Holmes, but it is also the method of science. Surely you would like to become scientific under the guidance of that great man. Of course you are not to be Watsons, but actual detectives, with Watsons of your own to admire you. And lest you should fear that the scientific method is alarmingly difficult, I may add that the method of Zadig or Sherlock Holmes, or of science in general, is nothing more than glorified common-sense.

It is difficult to talk about a subject which interests one without seeming to claim that it is superior to all others. I have not meant to imply this. I have only tried to explain in what way science differs from some other sort of knowledge. Nor do I wish to imply that the mind that excels in science is better or worse than that which one finds in a great literary man. An eminent oar is worthy of as much respect as a great cricketer, but he is eminent in a different way.

I am glad to think that there are points in which science, literature, and art are equally excellent-namely, in giving to mankind some of the deepest pleasures of which he is capable, in making him realise the wonder, the beauty and the romance of the world. I spoke of the power of science in knitting together isolated facts into a 
theory. And such a theory may become so all embracing that it is called a law of nature. Those great generalisations, the laws of gravity and the laws of evolution, or the laws of chemical combination, have a beauty and dignity which appeal to everyone.

And on the practical rather than on the theoretical, side there is wonder, and to my mind beauty, in the bigness and in the smallness of the spaces that man can deal with. The astronomer measures out his work, not by miles, but by the inconceivable distance that light can travel in a year. The man who studies bacteria measures by the micron, 25,000 of which go to the inch. To me there is more fascination in the very small than in the other extreme. It is wonderful to think that a plant-a big tree for instance-is made up of countless millions of cells, each of which was built by a minute protoplasmic body, which Huxley has compared to a delicate Ariel imprisoned like Shakespeare's sprite in an oak-tree.

There is a dramatic effect in even the simplest of experiments. I, for one, am never weary of the time-honoured demonstration of a water-plant giving off oxygen as it assimilates. A twig of Elodea in a large beaker of water gives off no bubbles in the dull light at the back of the room, but when close to the window it does so. And with proper precautions the rate of bubbling becomes an accurate measure of the intensity of assimilation. To complete the demonstration the experiment should be repeated with water which has been boiled, and therefore roughly freed from $\mathrm{CO}_{2}$, when 
the rate of bubbling is very greatly diminished. Finally, by blowing vigorously into the water it may be charged once more with $\mathrm{CO}_{2}$, and the normal rate of bubbling may be established.

There are of course innumerable experiments in pure chemistry and physics which have this romantic quality in the manner in which they reveal the secrets of the invisible structure of matter-but of these I have not much personal experience.

I think, too, that the human interest of science should always be encouraged. I mean that those classical experiments, by which great men have advanced human knowledge, should be shown: and performed moreover by the original methods, e.g. the discoveries of Black, Priestley and Cavendish.

After all, the real fun of science begins when one finds out something that was not known before. This is what is rather pompously called original research. It is interesting to see in my father's life how the sporting instinct gave way to the love of discovery. To show this passionate love of sport, he mentions that when as a boy he had just shot his first snipe, his hands trembled so that he could hardly reload his gun. Yet the same boy on the voyage of the Beagle found out how much more entrancing than shooting was the chase of new facts and new theories, and he handed over his gun to his servant. And something of this delight one may have as the merest learner. You are not likely to find out things that nobody knew before, but you may easily find out things quite new to yourself-which to you personally are as good as 
the brand-newest discovery. Lastly, there is another excellent reason for scientific work, namely, that the bodily welfare of the human race and of its friendly animals and plants depends. on accurate knowledge of the nature and behaviour of everything in the world. It is this truth that makes us believe that every fact has its value. Its value may remain unrecognised for long periods, and then it may suddenly find its place in the great jig-saw puzzle of knowledge. The two most exciting sciences just now seem to me to be Physics and Pathology; one as bringing us nearer to the knowledge of the structure of matter, the other in disentangling the causes of deadly and mysterious diseases such as malaria, diphtheria, hydrophobia, sleeping sickness, in a manner and with a success hitherto undreamt of. But because the advances in these sciences are so brilliant and hopeful, no civilised worker will venture to despise the pursuits of less fortunate people whose work seems rather humdrum. There are botanists who spend their whole lives in describing and classifying dried plants in a herbarium. But these are really doing highly valuable work, for the simple reason that we cannot make any accurate use of plants until they have names. I am omitting the purely commercial use of such work, which is very great. I only want to insist that the mere naming of living things is an indispensable stone in the building of the palace of science. All who work at science may recognise that they belong to a guild which makes for the happiness of the human race. And this they must do, not with any pride, but humbly 


\section{NULLIUS IN VERBA}

acknowledging how small is their personal share in the total of progress.

The Darwin Buildings, that is to say, the three new laboratories which are open to-day, were absolutely needed to carry out the Head Master's plan of giving every boy in the School a chance of learning science. When I say that at the present time 270 boys under five masters are at work in the laboratories, you will realise to what good use they are being put. As I happen to represent the Royal Society on your Governing Body it is especially satisfactory to me to know that science is here taught on the principle expressed by the motto of the Society : "Nullius in verba," that is to say, not in other people's words, but in your own observation lies the path of Science. 


\section{$\mathrm{X}$ \\ SIR GEORGE DARWIN ${ }^{1}$}

George Howard, the fifth ${ }^{2}$ child of Charles and Emma Darwin, was born at Down, July 9th, i 845 . Why he was christened ${ }^{3}$ George, I cannot say. It was one of the facts on which we founded a theory that our parents lost their presence of mind at the font, and gave us names for which there was neither the excuse of tradition nor of preference on their own part. His second name, however, commemorates his great-grandmother, Mary Howard, the first wife of Erasmus Darwin. It seems possible that George's ill-health and that of his father were inherited from the Howards. This, at any rate, was Francis Galton's view, who held that his own excellent health was a heritage from Erasmus Darwin's second wife. George's second name, Howard, has a certain appropriateness in his case, for he was the genealogist and herald of our family, and it is through Mary Howard that the Darwins can, by an excessively devious route, claim descent

1 Reprinted, with corrections (by the kind permission of the Syndics of the University Press), from Vol. v. of Sir G. Darwin's Scientific Papers. The biographical sketch of my brother is reproduced in a somewhat abbreviated version and does not contain Prof. E. W. Brown's contribution.

2 The third of those who survived childhood.

${ }^{3}$ At Maer, the Staffordshire home of his mother. 
from certain eminent people, e.g. John of Gaunt. This is shown in the pedigrees which George wrote out, and in the elaborate genealogical tree published in Professor's Pearson's Life of Francis Galton. George's parents had moved to Down in September 1842 , and he was born to those quiet surroundings of which Charles Darwin wrote, "My life goes on like clock-work, and I am fixed on the spot where I shall end it." It would have been difficult to find a more retired place so near London. In 1842 a coach drive of some twenty miles was the only means of access to Down; and even now that railways have crept closer to it, it is singularly out of the world, with little to suggest the neighbourhood of London, unless it be the dull haze of smoke that sometimes clouds the sky. In 1842 such a village, communicating with the main lines of traffic only by stony tortuous lanes, may well have been enabled to retain something of its primitive character. Nor is it hard to believe in thesmugglers and their strings of pack-horses making their way up from the lawless old villages of the Weald, of which the memory then still lingered. ${ }^{1}$

George retained throughout life his deep love for Down. For the lawn with its bright strip of flowers, and for the row of big lime trees that bordered it; for the two yew trees between which we children had our swing, and for many another characteristic which had become as dear and as familiar to him as a human face. He retained his youthful love of the "Sand-walk," a little wood far

${ }^{1}$ Life and Letters of Charles Darwin, Vol. I., p. 319. 
enough from the house to have for us a romantic character of its own.

George loved the country round Down, and all its dry chalky valleys of ploughed land, with "shaws," i.e. broad straggling hedges on their crests, bordered by strips of flowery turf. The country is traversed by many foot-paths; these George knew well and used skilfully in our walks, in which he was generally the leader. His love for the house and the neighbourhood was, I think, entangled with his deepest feelings. In later years his children came with their parents to Down, and they vividly remember his excited happiness, and how he enjoyed showing them his ancient haunts.

In this retired region Charles Darwin's children led a singularly quiet life, practically without friends, and dependent on their brothers and sisters for companionship. George's earliest recollection was of drumming with his spoon and fork on the nursery table because dinner was late, while a barrel-organ played outside. Other memories were less personal; for instance, the firing of guns when Sebastopol was supposed to have been taken. His diary of 1852 shows a composite interest in current events and in the picturesqueness of Natural History : "The Duke is dead. Dodos are out of the world."

He perhaps carried rather far the good habit of re-reading one's favourite authors. He told his children that for a year or so he read through every day the story of Jack the Giant Killer, in a little chap-book with coloured pictures. He early showed 
signs of the energy which marked his character in later life. I am glad to remember that I became his companion and willing slave. There was much playing at soldiers, and I have a clear remembrance of our marching with toy guns and knapsacks across the field to the Sand-walk. There we made our bivouac with gingerbread, and milk warmed (and generally smoked) over a "touch-wood" fire. I was a private while George was a sergeant, and it was part of my duty to stand sentry at the far end of the kitchen-garden until released by a buglecall from the lawn. I have a vague remembrance of presenting my fixed bayonet at my father to ward off a kiss, which seemed to me inconsistent with my military duties. Our imaginary names and heights were written up on the wall of the cloak-room. George, with romantic exactitude, made a small foot rule of such a size that he could conscientiously record his height as 6 feet, and mine as slightly less, in accordance with my age and station.

Under my father's instruction George made spears with weighted heads, which he hurled with remarkable skill by means of an Australian throwing stick. I used to skulk behind the big lime trees on the lawn in the character of victim, and I still remember the look of the spear flying through the air with a certain venomous waggle. Indoors, too, we threw at each other wooden javelins, which we received on beautiful shields made by the village carpenter and decorated with coats of arms.

Heraldry was a serious pursuit of his for many 
years, and the London Library copies of Guillim and Edmonson ${ }^{1}$ were generally at Down. $\mathrm{He}$ retained a love of the science through life, and his copy of Percy's Reliques is decorated with coats of arms admirably drawn and painted. In later life he showed a power of neat and accurate draughtsmanship, and some of the illustrations in his father's books, e.g. in Climbing Plants, are by his hand.

His early education was given by governesses, but the boys of the family used to ride twice or thrice a week to be instructed in Latin by Mr. Reed, the Rector of Hayes-the kindest of teachers. For myself, I chiefly remember the cake we used to have at I I o'clock, and the occasional diversion of looking at the pictures in the great Dutch Bible. George must have impressed his parents with his solidity and self-reliance, since he was more than once allowed to undertake alone the 20 -mile ride to the house of a relative at Hartfield in Sussex. For a boy of ten to bait his pony and order his luncheon at the Edenbridge inn was probably more alarming than the rest of the adventure. There is indeed a touch of David Copperfield in his recollections as preserved in family tradition. The waiter always said, "What will you have for lunch, Sir?" to which he replied, "What is there?" and the waiter said, "Eggs and bacon"; and though he hated bacon more than anything else in the world, he felt obliged to have it.

'Guillim, John, A Display of Heraldry, 6th ed., folio 1724. Edmonson, J., A Complete Body of Heraldry, folio, 1780. 
On August 16th, 1856, George was sent to school. Our elder brother, William, was at Rugby, and his parents felt his long absences from home such an evil that they fixed on the Clapham Grammar School for their younger sons. Besides its nearness to Down, Clapham had the merit of giving more mathematics and science than could then be found in public schools. It was kept by the Rev. Charles Pritchard, ${ }^{1}$ a man of strong character, and with a gift for teaching mathematics by which George undoubtedly profited. In, I think, I861 Pritchard left Clapham and was succeeded by the Rev. Alfred Wrigley, a man of kindly mood but without the force or vigour of Pritchard. As a mathematical instructor I imagine Wrigley was a good drillmaster rather than an inspiring teacher. Under him the place degenerated to some extent; it no longer sent so many boys to the Universities, and became more like a "crammer's" and less like a public school. My own recollections of George at Clapham are coloured by an abiding gratitude for his kindly protection of me as a shrinking and very unhappy "new boy" in 1860 .

George record's in his diary that in 1863 he tried in vain for a Minor Scholarship at St. John's College, Cambridge, and again failed to get one at Trinity in 1864, though he became a Foundation Scholar in 1866 . These facts suggested to me that his capacity as a mathematician was the result of slow growth. I accordingly applied to Lord

1 Afterwards Savilian Professor of Astronomy at Oxford. Born 1808 , died 1893 . 
Moulton, who was kind enough to give me his impressions :

My memories of your brother during his undergraduate career correspond closely to your suggestion that his mathematical power developed somewhat slowly and late. Throughout most, if not the whole, of his undergraduate years he was in the same class as myself and Christie, the ex-Astronomer Royal, at Routh's. ${ }^{1}$ We all recognised him as one who was certain of being high in the Tripos, but he did not display any of that colossal power of work and taking infinite trouble that characterised him afterwards. On the contrary, he treated his work rather jauntily. At that time his health was excellent and he took his studies lightly, so that they did not interfere with his enjoyment of other things. ${ }^{2}$ I remember that as the time of the examination came near I used to tell him that he was unfairly handicapped in being in such robust health and such excellent spirits.

Even when he had taken his degree I do not think he realised his innate mathematical power...It has been a standing wonder to me that he developed the patience for making the laborious numerical calculations on which so much of his most original work was necessarily based. He certainly showed no tendency in that direction during his undergraduate years.

1 The late Mr. Routh was the most celebrated mathematical "Coach" of his day.

${ }^{2}$ Compare Charles Darwin's words: "George has not slaved himself, which makes his success the more satisfactory" (More Letters of C. Darwin, Vol. 11., p. 287). 
Indeed, he told me more than once in later life that he detested arithmetic, and that these calculations were as tedious and painful to him as they would have been to any other man, but that he realised that they must be done, and that it was impossible to train anyone else to do them.

As a Freshman he 'kept' (i.e. lived) in A 6, the staircase at the N.W. corner of the New Court, afterwards moving to $\mathrm{F} 3$ in the Old Court, pleasant rooms entered by a spiral staircase on the south side of the Great Gate. Below him, in the ground floor room, now used as the College offices, lived Mr. Colvill, who remained a faithful but rarely seen friend as long as George lived.

Lord Moulton, who, as we have seen, was a fellow pupil of George's at Routh's, was held even as a Freshman to be an assured Senior Wrangler, a prophecy that he easily made good. The second place was held by George, and was a much more glorious position than he had dared to hope for. In those days the examiners read out the list in the Senate House at an early hour, 8 a.m. I think. George remained in bed and sent me to bring the news. I remember charging out through the crowd the moment the magnificent "Darwin of Trinity" had followed the expected "Moulton of St. John's." I have a general impression of a cheerful crowd sitting on George's bed and literally almost smothering him with congratulations. He received the following characteristic letter from his father ${ }^{\mathbf{1}}$ : p. 187 .

1 Emma Darwin, A Century of Family Letters, 1915, Vol. II., 
Down, Jan. 24th [1868].

My dear old fellow,

I am so pleased. I congratulate you with all my heart and soul. I always said from your early days that such energy, perseverance and talent as yours would be sure to succeed : but I never expected such brilliant success as this. Again and again I congratulate you. But you have made my hand tremble so I can hardly write. The telegram came here at eleven. We have written to W. and the boys.

God bless you, my dear old fellow-may your life so continue.

Your affectionate Father,

Ch. DARwin.

In those days the Tripos examination was held in the winter, and the successful candidates got their degrees early in the Lent Term. George records in his diary that he took his B.A. on January 25th, 1868; also that he won the second of the two Smith's Prizes-the first being the natural heritage of the Senior Wrangler. There is little to record in this year. $\mathrm{He}$ had a pleasant time in the summer, coaching Clement, the nephew of Sir Charles Bunbury, at his beautiful place Barton Hall in Suffolk. In the autumn he was elected a Fellow of Trinity, as he records, "with Galabin, young Niven, Clifford, [Sir Frederick] Pollock, and [Sir Sidney] Colvin." W. K. Clifford was the well-known brilliant mathematician who died comparatively early.

Chief among his Cambridge friends were the 
brothers Arthur, Gerald, and Frank Balfour. The last-named was killed, aged $3 \mathrm{I}$, in a climbing accident in 1882 on the Aiguille Blanche near Courmayeur. He was remarkable both for his scientific work and for his striking and most lovable personality. George's affection for him never faded. His daughter remembers her father (not long before his death) saying with emotion, "I dreamed Frank Balfour was alive." I imagine that tennis was the means of bringing George into contact with Mr. Arthur Balfour. What began in this chance way grew into an enduring friendship, and George's diary shows how much kindness and hospitality he received from $\mathrm{Mr}$. Balfour. George had also the advantage of knowing Lord Rayleigh at Cambridge, and retained his friendship through his life.

In the spring of 1869 he was in Paris for two months working at French. His teacher used to make him write original compositions, and George gained a reputation for humour by giving French versions of all the old Joe Millers and ancient stories he could remember.

It was his intention to make the Bar his profession, ${ }^{1}$ and in October 1869 we find him reading with Mr. Tatham, in 1870 and 1872 with the late Mr. Montague Crackenthorpe (then Cookson), and in November $187 \mathrm{r}$ he was a pupil of Mr. W. G. Harrison. The most valued result of his legal work was the friendship of Mr. and Mrs. Crackenthorpe, which he retained throughout his

${ }^{1} \mathrm{He}$ was called in 1874 but did not practise. 
life. During these years we find the first indications of the circumstances which forced him to give up a legal career-namely, his failing health and his growing inclination towards science. ${ }^{1}$ Thus in the summer of 1869, when we were all at Caerdeon in the Barmouth valley, he writes that he "fell ill," and again in the winter of $187 \mathrm{I}$. His health deteriorated markedly during 1872 and 1873 . In the former year he went to Malvern and to Homburg without deriving any advantage. I have an impression that he did not expect to survive these attacks, but I cannot say at what date he made this forecast of an early death. In January 1873 he visited Cannes, and "came back very ill." It was in the spring of this year that he first consulted Dr. (afterwards Sir Andrew) Clark, from whom he received the kindest care. George suffered from digestive troubles, sickness, and general discomfort and weakness. Dr. Clark's care probably did what was possible to make life more bearable, and as time went on his health gradually improved. In 1894 he consulted the late Dr. Eccles, and by means of the rest-cure, then something of a novelty, his weight increased from 9 stone to 9 stone II pounds. I gain the impression that this treatment produced a permanent improvement, although his health remained a serious handicap throughout his life.

I As a boy he had energetically collected Lepidoptera during the years $1858-6 r$; the first vague indications of a leaning towards physical science may perhaps be found in his joining the Sicilian eclipse expedition, December, 1870-January, 187I. It appears from Nature, December I, 1870 , that George was told off to make sketches of the Corona. 
Meanwhile he had determined on giving up the $\mathrm{Bar}$, and settled in October 1873 , when he was 28 years old, at Trinity in Nevile's Court next the Library ( $\mathrm{G} 4$ ). His diary continues to contain records of ill-health and of various holidays in search of improvement. Thus in 1873 we read, "Very bad during January. Went to Cannes and stayed till the end of April." Again in 1874, "February to July very ill." In spite of unwellness he began in 1872-3 to write on various subjects. He sent to Macmillan's Magazine ${ }^{1}$ an entertaining article, "Development in Dress," where thesurvivals in modern costume were recorded and discussed from the standpoint of evolution. In 1873 he wrote "On beneficial restriction to liberty of marriage," a eugenic article for which he was attacked with gross unfairness and bitterness by the late St. George Mivart. He was defended by Huxley; and Charles Darwin formally ceased all intercourse with Mivart. We find mention of a "Globe Paper for the British Association" in 1873. And in the following year he read a contribution on "Probable Error" to the Mathematical Society ${ }^{3}$ on which he writes in his diary, "found it was old." Besides another paper in the Messenger of Mathematics, he reviewed "Whitney on Language," and wrote a "Defence of Jevons" which I have not been able to trace. In 1875 he was at work on the

1 Macmillan's Magazine, 1872, Vol. xxv1., pp. 410-416.

2 Contemporary Review, I873, Vol. xxir., pp. 412-426.

- Not published.

- Contemporary Review, 1874, Vol. xxIV., pp. 894-904. 
"Flow of Pitch," on an "Equipotential Tracer," on slide rules, and sent a paper on "Cousin Marriages" to the Statistical Society. ${ }^{1}$ It is not my province to deal with these papers; they are enumerated here as showing his activity of mind and his varied interests,-features in his character which were notable throughout life.

The most interesting entry in his diary for 1875 is a "Paper on Equipotentials much approved by Sir W. Thomson." This is the first notice of an association of primary importance in George's scientific career. Then came his memoir, "On the influence of geological changes in the earth's axis of rotation." Lord Kelvin was one of the referees appointed by the Council of the Royal Society to report on this paper, which was published in the Philosophical Transactions in 1877 .

In his diary, November 1878, George records, "Paper on tides ordered to be printed." This refers to his work, "On the bodily tides of viscous and semi-elastic spheroids, etc.," published in the Phil. Trans. in 1879. It was in regard to this paper that his father wrote to George on October 29th, $1878^{2}$ :

My dear old George,

I have been quite delighted with your letter and read it all with eagerness. You were very good to write it. All of us are delighted, for considering what a man Sir

1 Journal of the Statistical Society, 1875, Vol. xxxvir., pt. 2, pp. 153-182, also pp. 183-184, and pp. 344-348.

2 Probably he heard informally at the end of October what was not formally determined till November. 
William Thomson is, it is most grand that you should have staggered him so quickly, and that he should speak of your 'discovery, etc.'... Hurrah for the bowels of the earth and their viscosity, and for the moon and for the Heavenly bodies, and for my son George (F.R.S. very soon)....1

The bond of pupil and master between George Darwin and Lord Kelvin, originating in the years $1877-8$, was to be a permanent one, and developed, not merely into scientific co-operation, but into a close friendship. Sir Joseph Larmor has recorded ${ }^{2}$ that George's "tribute to Lord Kelvin, to whom he dedicated Volume I of his Collected Papers ${ }^{3} . .$. gave lively pleasure to his master and colleague." His words were :

Early in my scientific career it was my good fortune to be brought into close personal relationship with Lord Kelvin. Many visits to Glasgow and to Largs have brought me to look up to him as my master, and I cannot find words to express how much I owe to his friendship and to his inspiration.

During these years there is evidence that he continued to enjoy the friendship of Lord Rayleigh and of Mr. Balfour. We find in his diary records

${ }^{1}$ Emma Darwin, A Century of Family Letters, 1915, Vol. Ir., p. 233 .

2 Nature, December I2, I9I2.

3 It was in 1907 that the Syndics of the Cambridge University Press asked George to prepare a reprint of his scientific papers, which were published in five volumes. George was deeply gratified at an honour that placed him in the same class as Lord Kelvin, Stokes, Cayley, Adams, Clerk Maxwell, Lord Rayleigh, and other men of distinction. 
of visits to Terling and to Whittingehame, or of luncheons at Mr. Balfour's house in Carlton Gardens, for which George's scientific committee work in London gave frequent opportunity. In the same way there are many records of visits to Francis Galton, with whom he was united alike by kinship and affection.

Few people indeed can have taken more pains to cultivate friendship than did George. This trait was the product of his affectionate and eminently sociable nature, and of his characteristic energy and activity. In earlier life he travelled a good deal in search of health, ${ }^{1}$ and in after years he attended numerous congresses as a representative of scientific bodies. He thus had unusual opportunities of making the acquaintance of men of other nationalities, and some of his warmest friendships were with foreigners. In passing through Paris he rarely failed to visit M. and Mme d'Estournelles and "the d'Abbadies." It was in Algiers in 1878 and 1879 that he cemented his friendship with the late J. F. MacLennan, author of Primitive Marriage; and in 1880 he was at Davos with the same friends. In $188 \mathrm{I}$ he went to Madeira, where he received much kindness from the Blandy family-doubtless through the recommendation of Lady Kelvin.

\section{Cambridge.}

We have seen that George was elected a Fellow of Trinity in October 1868 , and that five years

1 Thus in 1872 he was in Homburg, 1873 in Cannes, 1874 in Holland, Belgium, Switzerland and Malta, 1876 in Italy and Sicily 
later (October 1873) he began his second lease of a Cambridge existence. There is at first little to record: he held at this time no official position, and when his Fellowship expired he continued to live in College, busy with his research work, and laying down the earlier tiers of the monumental series of papers which he gave to the world. This soon led to his being proposed (in November 1877) for the Royal Society, and elected in June 1879 . The principal event in this stage of his Cambridge life was his election in 1883 as Plumian Professor of Astronomy and Experimental Philosophy. ${ }^{1}$ His predecessor in the Chair was Professor Challis, who had held office since 1836, and is now chiefly remembered in connection with Adams and the planet Neptune. The professorship is not necessarily connected with the Observatory, and practical astronomy formed no part of George's duties. His lectures being on advanced mathematics usually attracted but few students; in the Long Vacation, however, when he habitually gave one of his courses, there was often a fairly large class.

1 The voting at University elections is in theory strictly confidential, but in practice this is unfortunately not always the case. George records in his diary the names of the five who voted for him and of the four who supported another candidate. None of the electors are now living. The election occurred in January, and in June he had the great pleasure and honour of being re-elected to a Trinity Fellowship. His daughter, Madame Raverat, writes : " Once, when I was walking with my father on the road to Madingley village, he told me how he had walked there on the first Sunday he ever was at Cambridge with two or three other freshmen; and how, when they were about opposite the old chalk pit, one of them betted him $£ 20$ that he (my father) would never be a professor of Cambridge University: ' and ' said my father, with great indignation, "he never paid me." 
George's relations with his class have been sympathetically treated by Professor E. W. Brown, ${ }^{1}$ than whom no one can speak with more authority, since he was one of my brother's favourite pupils.

In the late '7o's George began to be appointed to various University Boards and Syndicates. Thus from $1878-82$ he was on the Museums and Lecture Rooms Syndicate. In 1879 he was placed on the Observatory Syndicate, of which he became an official member in 1883 on his election to the Plumian Professorship. In the same way he was on the Special Board for Mathematics. He was a member of the Financial Board from 1900-I to 1903-4, and on the Council of the Senate in 1905-6 and 1908-9. But he never became a professional syndic-one of those virtuous persons who spend their lives in University affairs. In his obituary of George (Nature, December 12, 1912), Sir Joseph Larmor writes :

In the affairs of the University, of which he was an ornament, Sir George Darwin made a substantial mark, though it cannot be said that he possessed the patience in discussion that is sometimes a necessary condition to taking a share in its administration. But his wide acquaintance and friendships among the statesmen and men of affairs of the time, dating often from undergraduate days, gave him openings for usefulness on a wider plane. Thus, at a time when residents were bewailing even more than usual the inadequacy of the

1 In the second part of the Preface to the fifth volume of Sir G. H, Darwin's Scientific Papers, rg16. 
resources of the University for the great expansion which the scientific progress of the age demanded, it was largely on his initiative that, by a departure from all precedent, an unofficial body was constituted in 1899 under the name of the Cambridge University Association, to promote the further endowment of the University by interesting its graduates throughout the Empire in its progress and its more pressing needs. This important body, which was organised under the strong lead of the late Duke of Devonshire, then Chancellor, comprises as active members most of the public men who owe allegiance to Cambridge, and has already by its interest and help powerfully stimulated the expansion of the University into new fields of national work, though it has not yet achieved financial support on anything like the scale to which American seats of learning are accustomed.

The Master of Christ's writes :

\section{May 3ist, 1915.}

My impression is that George did not take very much interest in the petty details which are so beloved by a certain type of University authority. 'Comma hunting' and such things were not to his taste, and at meetings he was often rather distrait, but when anything of real importance came up he was of extraordinary use. He was especially good at drafting letters, and over anything that he thought promoted the advancement of the University along the right lines he would take endless trouble-writing and re-writing reports and letters till he got them to his taste. The 
sort of movements which interested him most were those which connected Cambridge with the outside world. He was especially interested in the Appointments Board. A good many of us constantly sought his advice, and nearly always took it : but, as I say, I do not think he cared much about the 'parish pump,' and was usually worried at long meetings.

Professor Newall has also been good enough to give me his impressions :

His weight in the committees on which I have had personal experience of his influence seems to me to have depended in large measure on his realising very clearly the distinction between the importance of ends to be aimed at and the difficulty of harmonising the personal characteristics of the men who might be involved in the work needed to attain the ends. The ends he always took seriously-the crotchets he often took humorously, to the great easement of many situations that are liable to arise on a committee. I can imagine that to those who had corns his direct progress may at times have seemed unsympathetic and hasty. He was ready to take much trouble in formulating statements of business with great precision-a result doubtless of his early legal experiences. I recall how he would say, "If a thing has to be done, the minute should if possible make some individual responsible for doing it." He would ask, "Who is going to do the work? If a man has to take the responsibility, we must do what we can to help him, and not hamper him by unnecessary restrictions and criticisms." His helpfulness 
came from his quickness in seizing the important point and his readiness to take endless trouble in the important work of looking into details before and after the meetings. The amount of work that he did in response to the requirements of various Committees was very great, and it was curious to realise in how many cases he seemed to have diffidence as to the value of his contributions.

But on the whole, the work which, he was able to carry out, in addition to professional duties and research, was in matters of general importance unconnected with the University. To these we shall return.

In 1884 he became engaged to Miss Maud Du Puy of Philadelphia. She came of an old Huguenot stock, descending from Dr. John Du Puy, who was born in France in 1679, and settled in New York in 1713. They were married on July 22nd, 1884, and this event happily coloured the remainder of George's life. As time went on, and existence became fuller and busier, she was able by her never-failing devotion to shield him from fatigue and anxiety. In this way he was helped and protected in the various semi-public functions in which he took a principal part. Nor was her help valued only on these occasions, for indeed the comfort and happiness of every day was in her charge. There is a charming letter ${ }^{1}$ from George's mother, dated April I 5th, 1884:

Maud had to put on her wedding-dress in order to say at the Custom-house in America

I Emma Darwin, A Century of Family Letters. Privately printed, 1904, Vol. II., p. 350. 
that she had worn it, so we asked her to come down and show it to us. She came down with great simplicity and quietness...only really pleased at its being admired and at looking pretty herself, which was strikingly the case. She was a little shy at coming in, and sent in Mrs. Jebb to ask George to come out and see it first and bring her in. It was handsome and simple. I like seeing George so frivolous, so deeply interested in which diamond trinket should be my present, and in her new Paris morning dress, in which he felt quite unfit to walk with her.

Later, probably in June, George's mother wrote ${ }^{1}$ to Miss Du Puy, "Your visit here was a great happiness to me, as something in you (I don't know what) made me feel sure you would always be sweet and kind to George when he is ill and uncomfortable." These simple and touching words may be taken as a true forecast of his happy married life.

In March 1885 George acquired by purchase the house Newnham Grange, ${ }^{2}$ which remained his home to the end of his life. It stands at the southern end of the 'Backs,' within a few yards of the river where it bends eastward in flowing from the upper to the lower of the two Newnham watermills. I remember forebodings as to dampness, p. 266.

1 Emma Darwin, A Century of Family Letters, 1915, Vol. II.,

${ }^{2}$ At that time it was known simply as Newnham, but as this is the name of the College, and was also in use for a growing region of houses, the Darwins christened it Newnham Grange. The name Newnham is now officially applied to the region extending from Silver Street Bridge to the Barton Road. 
but they proved wrong-even the cellars being remarkably dry. The house is built of faded yellowish bricks, with old tiles on the roof, and has a pleasant home-like air. It was formerly the house of the Beales family, ${ }^{1}$ one of the old merchant stocks of Cambridge. This fact accounts for the great barn-like granaries which occupied much of the plot near the high road. These buildings were in part pulled down, thus making room for a lawn tennis court, while what was not demolished made a gallery looking on the court, as well as play-room for the children. At the eastern end of the property a cottage and part of the granaries were converted into a small house of an attractively individual character, for which I think tenants have hitherto been easily found among personal friends. One of the most pleasant features of the Grange was the flower-garden and rockery on the other side of the river, reached by a wooden bridge and called "the Little Island." 2 The house is conveniently close to the town, yet has a most pleasant outlook,

1 The following account of Newnham Grange is taken from C. H. Cooper's Memorials of Cambridge, I866, Vol. III., p. 26? (note) : "The site of the hermitage was leased by the Corporation to Oliver Grene, 20 September, 3I Eliz. [1 $5^{89}$ ]. It was in 1790 leased for a long term to Patrick Beales, from whom it came to his brother, S. P. Beales, Esq., who erected thereon a substantial mansion and mercantile premises now occupied by his son, Patrick Beales, Esq., alderman, who purchased the reversion from the Corporation in i 839." Silver Street was formerly known as Little Bridges Street, and the bridges which gave it this name were in charge of a hermit, hence the above reference to the hermitage.

2This was to distinguish it from the "Big Island," both being leased from the town. Later George acquired in the same way the small oblong kitchen garden on the river bank, and bought the freehold of the Lammas land on the opposite bank of the river. 
to the north over the Backs while there is the river and the Fen to the south. The children had a den or house in the branches of a large copper beech tree overhanging the river. They were allowed to use the boat, which was known as the Griffin, from the family crest with which it was adorned. None of them were drowned, though accidents were not unknown; in one of these an eminent lady and well-known writer, who was inveigled on to the river by the children, had to wade to shore near Silver Street bridge owing to the boat running aground.

The Darwins had five children, of whom one died an infant: of the others, Charles Galton Darwin has inherited much of his father's mathematical ability, and has been elected to a Mathematical Lectureship at Christ's College. He is now in the Army, and employed in research work in France. The younger son, William, has a commission in the 18 th Battalion of the Durham Light Infantry, and is now working with his brother. George's elder daughter is married to Monsieur Jacques Raverat. Her skill as an artist has perhaps its hereditary root in her father's draughtsmanship. The younger daughter, Margaret, is married to Mr. Geoffrey Keynes.

George's relations with his family were most happy. His diary never fails to record the dates on which the children came home, or the black days which took them to school. There are constantly recurring entries in his diary of visits to the boys at Marlborough or Winchester, or of the journeys to arrange for the schooling of the girls in England 
or abroad. The parents took pains that their children should have opportunities of learning conversational French and German.

George's characteristic energy showed itself not only in these ways but also in devising bicycling expeditions and informal picnics for the whole family, to the Fleam Dyke, to Whittlesford, or other pleasant spots near home; and these excursions he enjoyed as much as anyone of the party. As he always wished to have his children with him, one or more generally accompanied him and his wife when they attended congresses or other scientific gatherings abroad.

His house was the scene of many Christmas dinners, the first of which I find any record being in 1886. These meetings were often made an occasion for plays acted by the children; of these the most celebrated was a Cambridge version of Romeo and Juliet, in which the hero and heroine were scions of the rival factions of Trinity and St. John's.

\section{Games and Pastimes.}

As an undergraduate George played tennisnot the modern out-door game, but that regal pursuit which is sometimes known as the game of kings and otherwise as the king of games. When George came up as an undergraduate there were two tennis courts in Cambridge, one in the East Road, the other being the ancient one that gave its name to Tennis Court Road, and was pulled down to make room for the new buildings of 
Pembroke. In this way was destroyed the last of the College tennis courts of which we read in Mr. Clark's History. I think George must have had pleasure in the obvious development of the tennis court from some primæval farm-yard in which the pent-house was the roof of a shed, and the grille a real window or half-door. To one brought up on evolution there is also a satisfaction about the French terminology which survives in $e . g$. the Tambour and the Dedans. George put much thought into acquiring a correct style of play; for in tennis there is a religion of attitude corresponding to that which painfully regulates the life of the golfer. He became a good tennis player as an undergraduate, and was in the running for a place in the inter-University match. The marker at the Pembroke court was Henry Harradine, whom we all sincerely liked and respected, but he was not a good teacher, and it was only when George came under Henry's sons, John and Jim Harradine, at the Trinity and Clare court, that his game began to improve. He continued to play tennis for some years, and only gave it up after a blow from a tennis ball in January 1895 had almost destroyed the sight of his left eye.

In r 9 ro he took up archery, and zealously set himself to acquire the correct mode of standing, the position of the head and hands, etc. He kept an archery diary in which each day's shooting is carefully analysed and the results given in percentages. In 191 I he shot on I 3 I days : the last occasion on which he took out his bow was September I3, I9 2. 
I am indebted to Mr. H. Sherlock, who often shot with him at Cambridge, for his impressions. He writes: "I shot a good deal with your brother the year before his death; he was very keen on the sport, methodical and painstaking, and paid great attention to style, and as he had a good natural 'loose,' which is very difficult to acquire, there is little doubt (notwithstanding that he came to archery rather late in life) that had he lived he would have been above the average of the men who shoot fairly regularly at the public meetings." After my brother's death Mr. Sherlock was good enough to look at George's archery note-book. "I then saw," he writes, "that he had analysed them in a way which, so far as I am aware, had never been done before." Mr. Sherlock has given examples of the method in a sympathetic obituary published(p. 273)in The Archer's Register. ${ }^{1}$ George's point was that the traditional method of scoring is not fair in regard to the areas of the coloured rings of the target. Mr. Sherlock records in his Notice that George joined the Royal Toxophilite Society in 1912 , and occasionally shot in the Regent's Park. In 1912 he won the Norton Cup and Medal (144 arrows at 120 yards.)

There was a billiard table at Down, and George learned to play fairly well, though he had no pretension to real proficiency. He used to play at the Athenaeum, and in 191 I we find him playing there in the Billiard Handicap, but a week later he records in his diary that he was "knocked out."

1 The Archer's Register for 1912-1913, by H. Walrond. Iondon, The Field Office, r913. 


\section{Scientific Committees.}

George served for many years on the Solar Physics Committee and on the Meteorological Council. With regard to the latter, Sir Napier Shaw has at my request given me his impressions ${ }^{1}$ :

It was in February 1885 , upon the retirement of Warren De la Rue, that your brother George, by appointment of the Royal Society, joined the governing body of the Meteorological Office, at that time the Meteorological Council. He remained a member until the end of the Council in 1905, and thereafter, until his death, he was one of the two nominees of the Royal Society upon the Meteorological Committee, the new body which was appointed by the Treasury to take over the control of the administration of the Office. . . .

The Commissioners, collectively known as the Meteorological Council, were a remarkably distinguished body of Fellows of the Royal Society, and when Darwin took the place of De la Rue, the members were men subsequently famous, as Sir Richard Strachey, Sir William Wharton, Sir George Stokes, Sir Francis Galton, Sir George Darwin, with E. J. Stone, a former Astronomer Royal for the Cape

I do not think that Darwin addressed himself spontaneously to meteorological problems, but he was always ready to help. He was very regular in his attendance at Council, and the minutes show that after Stokes retired, all questions involving physical measurement or

${ }^{1}$ As here given they are abbreviated. 
mathematical reasoning were referred to him. There is a short and very characteristic report from him on the work of the harmonic analyser, and a considerable number upon researches by Mr. Dines or Sir G. Stokes on anemometers. It is hardly possible to exaggerate his aptitude for work of that kind. He could take a real interest in things that were not his own. $\mathrm{He}$ was full of sympathy and appreciation for efforts of all kinds, especially those of young men, and at the same time, using his wide experience, he was perfectly frank and fearless not only in his judgment but also in the expression of it. He gave one the impression of just protecting himself from boredom by habitual loyalty and a finely tempered sense of duty. My earliest recollection of him on the Council is the thrilling production of a new version of the Annual Report of the Council which he had written because the original had become more completely 'scissors and paste' than he could endure.

After the Office came into my charge in I900, so long as he lived I never thought of taking any serious step without first consulting him, and he was always willing to help by his advice, by his personal influence and by his special knowledge. For the first six years of the time I held a college fellowship, with the peculiar condition of four public lectures in the University each year and no emolument. One year, when I was rather overdone, Darwin took the course for me, and devoted the lectures to Dynamical Meteorology. I believe he got it up for the occasion, for he professed the utmost diffidence about it, but the progress 
which we have made in recent years in that subject dates from those lectures and the correspondence which arose upon them.

In Council it was the established practice to proceed by agreement and not by voting ; he had a wonderful way of bringing a discussion to a head by courageously 'voicing' the conclusion to which it led, and frankly expressing the general opinion without hurting anybody's feelings. . . .

It is not easy to give expression to the powerful influence which he exercised upon all departments of official meteorology without making formal contributions to meteorological literature. He gave me a note on a curious point in the evaluation of the velocity equivalents of the Beaufort Scale, which is published in the Office Memoirs No. 180 , and that is all I have to show in print, but he was in and behind everything that was done, and personally, I need hardly add, I owe to him much more than this or any other letter can fully express.

On May 6, 1904, the year of the South African meeting, he was elected President of the British Association.

On July 29, 1905, he embarked with his wife and his son Charles, and arrived on August i 5 at the Cape, where he gave the first part of his Presidential Address. Here he had the pleasure of finding as Governor, Sir Walter Hely-Hutchinson, whom he had known as a Trinity undergraduate. He was the guest of the late Sir David Gill, who remained a close friend for the rest of his life. George's diary gives his itinerary-which shows the 
trying amount of travel that he went through. A sample may be quoted :

$\begin{array}{crl}\text { August } & \text { 19 } & \text { Embark, } \\ \text {," } & 22 & \text { Arrive at Durban, } \\ \text {, } & 23 & \text { Mount Edgecombe, } \\ \text { ", } & 24 & \text { Pietermaritzburg, } \\ \text {," } & 26 & \text { Colenso, } \\ \text { ", } & 27 & \text { Ladysmith, } \\ \text {, } & 28 & \text { Johannesburg. }\end{array}$

At Johannesburg he gave the second half of his Address. Then on by Bloemfontein, Kimberley, Bulawayo, to the Victoria Falls, where a bridge had to be opened. Then to Portuguese Africa on September 16, 17, where he made speeches in French and English. Finally he arrived at Suez on October 4, and got home October 18.

It was generally agreed that his Presidentship was a conspicuous success. The following appreciation is from the obituary notice in The Observatory, January 1913, p. 58 :

The Association visited a dozen towns, and at each halt its President addressed an audience partly new, and partly composed of people who had been travelling with him for many weeks. At each place this latter section heard with admiration a treatment of his subject wholly fresh and exactly adapted to the locality.

Such duties are always trying, and it should not be forgotten that tact was necessary in a country which only two years before was still in the throes of war. 
In the autumn he received the honour of being made a K.C.B. The distinction was doubly valued as being announced to him by his friend Mr. Balfour, then Prime Minister.

From 1899 to 1900 he was President of the Royal Astronomical Society. One of his last Presidential acts was the presentation of the Society's Medal to his friend M. Poincaré.

He had the unusual distinction of serving twice as President of the Cambridge Philosophical Society, once in 1890-92 and again 1911-12.

In 189 I he gave the Bakerian Lecture ${ }^{1}$ of the Royal Society, his subject being "Tidal Prediction." This annual prælection dates from I775, and the list of lecturers is a distinguished roll of names.

In 1897 he lectured at the Lowell Institute at Boston, and this was the origin of his book on Tides, published in the following year. Of this Sir Joseph Larmor says ${ }^{2}$ that "it has taken rank with the semi-popular writings of Helmholtz and Kelvin as a model of what is possible in the exposition of a scientific subject." It has passed through three English editions, and has been translated into many foreign languages.

\section{International Associations.}

During the last ten or fifteen years of his life George was much occupied with various International bodies, e.g. the International Geodetic

1 See Prof Brown's Memoir, p. xlix.

2Nature, 1912. See also Prof. Brown's Memoir, p. 1. 
Association, the International Association of Academies, the International Congress of Mathematicians, and the Seismological Congress.

With regard to the last named it was in consequence of George's report to the Royal Society that the British Government joined the Congress. It was however with the Geodetic Association that he was principally connected.

Sir Joseph Larmor (Nature, December 12, 1912) gives the following account of the origin of the Association :

The earliest of topographic surveys, the model which other national surveys adopted and improved upon, was the Ordnance Survey of the United Kingdom. But the great trigonometrical survey of India, started nearly a century ago, and steadily carried on since that time by officers of the Royal Engineers, is still the most important contribution to the science of the figure of the earth, though the vast geodetic operations in the United States are now following it closely. The gravitational and other complexities incident on surveying among the great mountain masses of the Himalayas early demanded the highest mathematical assistance. The problems originally attacked in India by Archdeacon Pratt were afterwards virtually taken over by the Royal Society, and its secretary, Sir George Stokes, of Cambridge, became from 1864 onwards the adviser and referee of the survey, as regards its scientific enterprises. On the retirement of Sir George Stokes this position fell very largely to Sir George Darwin, whose relations with the India Office on this and other affairs 
remained close, and very highly appreciated, throughout the rest of his life.

The results of the Indian survey have been of the highest importance for the general science of geodesy....It came to be felt that closer co-operation between different countries was essential to practical progress and to coordination of the work of overlapping surveys.

For the further history of George's connection with the Association, I am indebted to the Secretary, Dr. van d. Sande Bakhuyzen.

On the proposal of the Royal Society the British Government, after having consulted the Director of the Ordnance Survey, in 1898, resolved upon the adhesion of Great Britain to the International Geodetic Association, and appointed as its delegate, G. H. Darwin. By his former researches and by his high scientific character, he, more than any other, was entitled to this position, which would afford him an excellent opportunity of furthering, by his recommendations, the study of theoretical geodesy....

We cannot relate in detail his valuable cooperation as a member of the Council in the various transactions of the Association, for instance, on the junction of the Russian and Indian triangulations through Pamir, but we must gratefully remember his great service to the Association when, at his invitation, the delegates met in 1909 for the 16th General Conference in London and Cambridge.

With the utmost care he prepared everything to render the Conference as interesting and agreeable as possible, and he fully suc- 
ceeded. Through his courtesy the foreign delegates had the opportunity of making the personal acquaintance of several members of the Geodetic staff of England and its colonies, and of other scientific men, who were invited to take part in the Conference; and when after four meetings in London the delegates went to Cambridge to continue their work, they enjoyed the most cordial hospitality from Sir George and Lady Darwin, who, with her husband, procured them in Newnham Grange happy leisure hours between their scientific labours.

At this conference Darwin delivered various reports, and at the discussion on Hecker's determination of the variation of the vertical by the attraction of the moon and sun, he gave an interesting account of the researches on the same subject made by him and his brother Horace more than 20 years ago, which unfortunately failed from the bad conditions of the places of observation.

In 1912 Sir George, though already overfatigued by the preparations for the Mathematical Congress in Cambridge, and the exertions entailed by it, nevertheless prepared the different reports on the geodetic work in the British Empire, but, alas, his illness prevented him from assisting at the conference at Hamburg, where they were presented by other British delegates. The conference thanked him, and sent him its best wishes, but at the end of the year the Association had to deplore the loss of the man who in theoretical geodesy as well as in other branches of mathematics and astronomy stood in the first rank, and who 
for his noble character was respected and beloved by all his colleagues in the International Geodetic Association.

Sir Joseph Larmor writes ${ }^{1}$ :

Sir George Darwin's last public appearance was as president of the fifth International Congress of Mathematicians, which met at Cambridge on August 22-28, 1912. The time for England to receive the congress having obviously arrived, a movement was initiated at Cambridge, with the concurrence of Oxford mathematicians, to send an invitation to the fourth congress held at Rome in 1908. The proposal was cordially accepted, and Sir George Darwin, as doyen of the mathematical school at Cambridge, became chairman of the organising committee, and was subsequently elected by the congress to be their president. Though obviously unwell during part of the meeting, he managed to discharge the delicate duties of the chair with conspicuous success, and guided with great verve the deliberations of the final assembly of what turned out to be a most successful meeting of that important body.

\section{Personal Characteristics.}

His daughter, Madame Raverat, writes :

I think most people might not realise that the sense of adventure and romance was the most important thing in my father's life, except his love of work. He thought about all life romantically, and his own life in particular;

1 Nature, December 12, 1912. 
one could feel it in the quality of everything he said about himself. Everything in the world was interesting and wonderful to him, and he had the power of making other people feel it.

He had a passion for going everywhere and seeing everything; learning every language, knowing the technicalities of every trade ; and all this emphatically not from the scientific or collector's point of view, but from a deep sense of the romance and interest of everything. It was splendid to travel with him; he always learned as much as possible of the language, and talked to everyone; we had to see simply everything there was to be seen, and it was all interesting, like an adventure. For instance, at Vienna I remember being taken to a most improper music hall, and at Schönbrunn hearing from an old forester the whole secret history of the old Emperor's son. My father would tell us the stories of the places we went to with an incomparable conviction and sense of the reality and dramaticness of the events. It is absurd, of course, but in that respect he always seemed to me a little like Sir Walter Scott. ${ }^{1}$

The books he used to read to us when we were quite small, and which we adored, were Percy's Reliques and the Prologue to the

Compare Mr. Chesterton's Twelve Types, (1903), p. I9o. He speaks of Scott's critic in the Edinburgh Review : "The only thing to be said about that critic is that he had never been a little boy, He foolishly imagined that Scott valued the plume and dagger of Marmion for Marmion's sake. Not being himself romantic, he could not understand that Scott valued the plume because it was a plume, and the dagger because it was a dagger." 
Canterbury Tales. He used often to read Shakespeare to himself, I think generally the historical plays; also Chaucer, Don Quixote in Spanish, and all kind of books like Joinville's Life of St. Louis in the old French.

I remember the story of the death of Gordon told so that we all cried, I think; and Gladstone could hardly be mentioned in consequence. All kinds of wars and battles interested him, and I think he liked archery more because it was romantic than because it was a game.

During his last illness his interest in the Balkan war never failed. Three weeks before his death he was so ill that the doctor thought him dying. Suddenly he rallied from the half-unconscious state in which he had been lying for many hours, and the first words he spoke on opening his eyes were, "Have they got to Constantinople yet?" This was very characteristic. I often wish he was alive now, because his understanding and appreciation of the glory and tragedy of this war would be like no one else's.

His daughter Margaret writes :

$\mathrm{He}$ was absolutely unselfconscious, and it never seemed to occur to him to wonder what impression he was making on others. I think it was this simplicity which made him so good with children. He seemed to understand their point of view, and to enjoy with them in a way that is not common with grown-up people. I shall never forget how when our dog had to be killed he seemed to feel the horror of it just as I did, and how this sense of his really sharing 
my grief made him able to comfort me as nobody else could.

He took a transparent pleasure in the honours that came to him, especially in his membership of foreign Academies, in which he and Sir David Gill had a friendly rivalry or "race," as they called it. I think this simplicity was one of his chief characteristics, though most important of all was the great warmth and width of his affections. He would take endless trouble about his friends, especially in going to see them if they were lonely or ill; and he was absolutely faithful and generous in his love.

After his mother came to live in Cambridge I believe he hardly ever missed a day in going to see her, even though he might only be able to stay a few minutes. She lived at some distance off, and he was often both busy and tired. This constancy was very characteristic. It was shown once more in his many visits to Jim Harradine, the marker at the tennis court, on what proved to be his death-bed.

His energy and his kindness of heart were shown in many cases of distress. For instance, a guard on the Great Northern Railway was robbed of his savings by an absconding solicitor, and George succeeded in collecting some $£ 300$ for him. In later years, when his friend the guard became bedridden, George often went to see him. Another man whom he befriended was a one-legged man at Balsham, whom he happened to notice in bicycling past. He took the trouble to see the village authorities, and succeeded in sending the man to London to be fitted with an artificial leg. 
In these and similar cases there was always the touch of personal sympathy. For instance, he pensioned the widow of his gardener, and he often made the payment of her weekly allowance the excuse for a visit.

In another sort of charity he was equally kindhearted, viz., in answering the people who wrote foolish letters to him on scientific subjects-and here as in many points he resembled his father.

His sister, Mrs. Litchfield, has truly said $^{1}$ of George, that he inherited his father's power of work and much of his "cordiality and warmth of nature, with a characteristic power of helping others." He resembled his father in another quality, that of modesty. His friend and pupil, Professor E. W. Brown, writes :

He was always modest about the importance of his researches. He would often wonder whether the results were worth the labour they had cost him, and whether he would have been better employed in some other way.

His nephew Bernard, speaking of George's way of taking pains to be friendly and forthcoming to anyone with whom he came in contact, says:

He was ready to take other people's pleasantness and politeness at its apparent value and not to discount it. If they seemed glad to see him, he believed that they were glad. If he liked somebody, he believed that the somebody liked him, and did not worry p. 146 .

1 Emma Darwin, A Century of Family Letters, 1915, Vol., II., 
himself by wondering whether they really did like him.

Of his energy we have evidence in the amount of material contained in his collected works. There was nothing dilatory about him, and here he again resembled his father, who had markedly the power of doing things at the right moment, and thus avoiding waste of time and discomfort to others. George had none of a characteristic which was defined in the case of Henry Bradshaw, as "always doing something else." After an interruption he could instantly reabsorb himself in his work, so that his study was not kept as a place sacred to peace and quiet.

His wife is my authority for saying that although he got so much done, it was not by working long hours. Moreover, the days that he was away from home made large gaps in his opportunities for steady application. His diaries show in another way that his researches by no means took all his time. He made a note of the books he read, and these make a considerable record. Although he read much good literature with honest enjoyment, he had not a delicate or subtle literary judgment. Nor did he care for music. He was interested in travels, history, and biography, and as he could remember what he read or heard, his knowledge was wide in many directions. His linguistic power was characteristic. He read many European languages. I remember his translating a long Swedish paper for my father. And he took pleasure in the Platt Deutsch stories of Fritz Reuter. 
The discomfort from which he suffered during the meeting at Cambridge of the International Congress of Mathematicians in August 1912 was, in fact, the beginning of his last illness. An exploratory operation showed that he was suffering from malignant disease. Happily he was spared the pain that gives its terror to this malady. His nature was, as we have seen, simple and direct, with a pleasant residue of the innocence and eagerness of childhood. In the manner of his death these qualities were ennobled by an admirable and most unselfish courage. As his vitality ebbed away his affection only showed the stronger. He wished to live, and he felt that his power of work and his enjoyment of life were as strong as ever, but his resignation to the sudden end was complete and beautiful. He died on December 7, 1912, and was buried at Trumpington.

Honours, Medals, Degrees, Societies, etc.

Order. K.C.B. 1905.

Medals. ${ }^{1}$

1883. Telford Medal of the Institution of Civil Engineers.

I884. Royal Medal. ${ }^{2}$

1892. Royal Astronomical Society's Medal.

i9i I. Copley Medal of the Royal Society.

1912. Royal Geographical Society's Medal.

1 Sir George's medals are deposited in the Library of Trinity College, Cambridge. Society.

${ }^{2}$ Given by the Sovereign on the nomination of the Royal 
Offices.

Fellow of Trinity College, Cambridge, and Plumian Professor in the University.

Vice-President of the International Geodetic Association, Lowell Lecturer at Boston U.S. (1897).

Member of the Meteorological and Solar Physics Committees.

Past President of the Cambridge Philosophical Society, Royal Astronomical Society, British Association.

Doctorates, etc., of Universities.

Oxford, Dublin, Glasgow, Pennsylvania, Padua (Socio onorario), Göttingen, Christiania, Cape of Good Hope, Moscow (honorary member).

Foreign or Honorary Membership of Academies, etc.

Amsterdam (Netherlands Academy), Boston (American Academy), Brussels (Royal Society), Calcutta (Math.Soc.), Dublin(Royal Irish Academy), Edinburgh (Royal Society), Halle (K. Leop.-Carol. Acad.), Kharkov (Math. Soc.), Mexico (Soc. "Antonio Alzate"), Moscow (Imperial Society of the Friends of Science), New York, Padua, Philadelphia (Philosophical Society), Rome (Lincei), Stockholm (Swedish Academy), Toronto (Physical Society), Washington (National Academy), Wellington (New Zealand Inst.).

1 Re-elected in 19 r. 
Correspondent of Academies, etc., at

Acireale (Zelanti), Berlin (Prussian Academy), Buda Pest (Hungarian Academy), Frankfort (Senckenberg. Natur. Gesell.), Göttingen (Royal Society), Paris, St. Petersburg, Turin, Istuto Veneto, Vienna. ${ }^{1}$

1 The above list is principally taken from that compiled by Sir George for the Year-Book of the Royal Society, r912, and may not be quite complete. It should be added that he especially valued the honour conferred on him in the publication of his collected papers by the Syndics of the University Press. 


\section{$\mathrm{XI}$ \\ WAR MUSIC}

An Address to a Society of Morris Dancers DeCEMBER 21, 1914

According to the Dictionary of Music ${ }^{1}$ the military march is meant "not only to stimulate courage but also to ensure the orderly advance of troops." In other words, military music serves to incite and to regulate movement. But these cannot always be discriminated. The tramp tramp of marching soldiers is ordered by the rhythm of the band. This is óbvious, but we cannot say how far the bravery of the tune puts strength into tired legs, and this would be incitement,-and how far it is the unappeasable rhythm that forces the men to keep going, and this may perhaps be called regulation. There are occasions when the trumpet comes as a signal to troops waiting to make some sublime effort, and where the fierce imperious sound has a lift and a sting which perhaps no preconcerted signal of a weaker type could give. This is an example of incitement, but in as much as it determines the moment of attack it is also a regulating agent.

${ }^{1}$ Dictionary of Music, ed. I., S.V., March. 
Marching is still of importance,-in spite of the part taken by railways in modern strategy. I should like to know whether the magnificent marches of the Russians are made to the accompaniment of a band or of the regimental choir. One sees in our volunteer army the tendency to sing on the march. But it must be allowed that neither words or tunes are particularly inspiring. The Englishman is habitually afraid of being solemn, and though his marching songs may contain good things they are apt to be treated in a light spirit. There is one which includes the words, "Rule, Rule, Britannia!" and "God Save the Queen!" but these famous phrases serve as chorus to lighthearted fragments, e.g. nursery rhymes, such as "Little Miss Muffett." I regret to add that even this classic is not respectfully used. It should run, "There came a great spider and sat down beside her and frightened Miss Muffett away." I forget the precise words of the parody, except its ending, "And Little Miss Muffett said, "Bother the creature!" I still remember the fine effect of German soldiers heard many years ago singing the "Wacht am Rhein" on the march. Once, too, I listened to Zouaves, and no greater contrast can be imagined. It was hardly more than a murmur, a chatter of diverse scraps, and had no inspiring effect. These magnificent troops may need no artificial stimulus, but ordinary folk are certainly kept going by martial music. I remember, as a boy, marching to the tune of the "British Grenadiers," which has foolish words, and is not striking from a musical point of view, but it seemed to take us along. 
This march-tune comes in finely in Rudyard Kipling's story of the Drums of the Fore and Aft. An untried British regiment is cut up by Afghans and retires in a helter-skelter rush, leaving behind two boys of the Band, who strike up the "British Grenadiers" with the solitary squeak of a fife and the despairing roll of a drum. The answer comes in a great cheer from the Highlanders and Gurkas waiting on the heights, and in a charge that turns defeat into victory. I wish that Kipling had allowed the boys to survive, but the tragedy of their death is after all the effective close. To return to marching-tunes. For average people all that is needed is a well marked rhythm: "John Brown's body," etc., is an admirable march, though taken from its context of tramping soldiers it is hardly a fine tune. But so far as words are concerned it must be allowed that the refrain, "His soul goes marching along," is in the right mood for a war song.

It may be objected that if all I want is rhythm I should be satisfied with instruments of percussion alone. To this I reply that the effect of drums is splendidly martial. I was at Aix at the outbreak of the war, and every day the regiment quartered there used to march out to the music of drums, and of bugles which played simple tunes on the common chord. When the buglers were out of breath, the drums thundered on with magnificent fire, until once more the simple and spirited fanfare came in with its brave out-of-doors flavour-a romantic dash of the hunting song, and yet with something of the seriousness of battle. And indeed this is the 
sort of melody that suits the dauntless spirit of our allies. As I watched these men, so soon to fight for their country, I was reminded of that white-faced boy pictured by Stevenson, striding over his dead comrades, the roll of his drum leading the living to victory or death. Drums are said (incorrectly I believe) to be made of donkey's skin, and Stevenson imagines how, after death, the poor beast takes this magical revenge for the blows received in life, by leading cruel man to destruction. The old English military music seems to have been played by drums alone. King Charles I issued a warrant in the following words": "Whereas ... the March of this our nation so famous in all honourable achievements and glorious warres of this our Kingdom in forraigne parts was through the negligence and carelessness of drummers ... so altered and changed from the ancient gravity and majestie thercof as it was in danger utterly to have been lost and forgotten. . . ." He therefore wills and commands drummers to play only what is recorded in the curious old notation of that day. It must be remembered that drums and trumpets had something of the sacredness of Royalty in the i 7 th century. No one was allowed to play them in public without a license from the Sergeant Trumpeter, ${ }^{2}$ an officer who certainly existed a few years ago, and may, for all I know, still survive.

1 Dictionary of Music, s.v., March.

${ }^{2}$ Dictionary of Music, s.v. Sergeant Trumpeter. When the office was revived in $185^{8}$ it was given to a clarinet player and then to a bassoonist. Before this date it was not even necessary to be a musician to hold the office. The salary is $t_{100}$ per annum. 
In the 17 th century it was a post of some dignity, and gave its holder the title of Esquire.

During the great retreat in the winter of 1914 the effect of music was magnificently illustrated. Mr. Conan Doyle ${ }^{1}$ writes, "Exhausted as the troops were, there could be no halt or rest until they had extricated themselves from the immediate danger. At the last point of human endurance they still staggered on through the evening and the night time, amid roaring thunder and flashing lightning, down the St. Quentin road. Many fell from fatigue, and having fallen continued to sleep. ... In the case of some of the men the collapse was so complete that it was almost impossible to get them on. Major Tom Bridges, of the 4 th Royal Irish Dragoons being sent to round up and hurry forward 250 stragglers at St. Quentin, found them nearly comatose with fatigue. With quick wit he bought a toy drum, and accompanied by a man with a penny whistle he fell them in and marched them, laughing in all their misery, down the high road towards Ham." When he stopped he found that the men stopped also, so he was compelled to march and play the whole way to Roupy.

In Sir Henry Newbolt's Song of the Great Retreat (The Times, Dec. 16, 1914), this triumphant success is described :

"Cheerly goes the dark road, cheerly goes the night,

Cheerly goes the blood to keep the beat :

1 The British Campaign in France and Flanders, 1914, pp. II7 and $1 \mathrm{I} 8$. 
Half a thousand dead men marching on to fight, With a little penny drum to lift their feet."

This song ought to be especially interesting to our Society, because the effect of a small drum and a penny whistle is roughly the same as that of the pipe and tabor, and these are the traditional instruments for English Folk Dances. It is perhaps worth noting that they must in old days have been used in war, for there is an illustration in an ancient manuscript of a taborer piping at the head of a body of troops marching out from a town.

Man is a social animal, and his natural strength lies in community of action with his fellows. It is this which gives music its power over masses of men, the pulsation of the drum, the blare of the answering trumpets, or the strident voice of the bagpipe cry to them in tones which cannot be misunderstood, binding them into a brotherhood of courage and obedience. But a society of Morris Dancers does not need to be reminded of the noble effect of human movement controlled by music. The word 'caper' has somewhat ridiculous associations, but we have learned to respect it for what is implies : the finely ordered strenuous movement of strong bodies leaping in rhythmic dance. It suggests something pagan and prehistoric, a physical religion of astonishing beauty. Some of our Morris men are now giving all the vigour of their young bodies to a great and just cause. Let us wish them a victorious home-coming. 


\section{XII}

\section{THE TEACHING OF SCIENCE ${ }^{1}$}

It is not difficult to sympathise with what Dr. Birkbeck aimed at in founding the College which bears his name. His idea seems to have been, that whatever a man's calling may be, he is the better for accurate knowledge of the things with which he deals. This is a sufficiently obvious statement. But if for the word 'accurate' we substitute 'scientific,' it is no longer a platitude - at least it is not so in the ears of the semi-educated. For we can still find people who believe in the "practical "man" as opposed to one whom they probably call a scientist. One would like to know more of the conception of science formed by the unscientific. They are probably unaware that science is eminently practical in asserting that only to be true which rests on wide and accurate generalisation. It is also practical wisdom to hold, as science does, that truth is temporary and relative, and is in fact merely the best conclusion that can be drawn in the present state of knowledge. To many people science is wearisome and somewhat ridiculous, and these qualities appear in the naturalist of fiction. Thus when even George Eliot draws a coleopterist, he is made a feeble old man shuffling to and fro among his 29th, 1913 .

'An Address given at Birkbeck College, London, on September 
ridiculous beetles. And on the French stage I have seen a botanist treated in the same spirit.

Positiveness and bumptiousness are also supposed to be our attributes. In the 'New Republic' the characters said to represent Huxley and Clifford are completely disguised by their pompous pretentiousness.

It is not difficult to describe the ideals of science, but it is only too easy to fall short of them. It is easy for instance to become a sectarian, to belong to a school, and to be literally incapable of fairness towards the opposition. This was plainly seen at the incoming of evolution, and it was one of the many glories of Sir Charles Lyell that he could accept the 'Origin of Species,' and that, in the words of Hooker, he could under-pin his work with an evolutionary foundation and find his edifice stronger than ever. But we need not consider the battles of giants; we are much more likely to be concerned with the mentally dwarfed or deformedwith the dangerous man who makes positive statements on insufficient data, or suffers from that other vice of not being able to confess ignorance. The only lectures which impressed me, as an undergraduate at Cambridge, were those of the late Sir George Humphry; and his most striking words were confessions of complete ignorance about many parts of physiology. Here is an instance of an opposite state of things, of a want of courage. An eminent chemist was asked why common salt thrown on the fire gives a blue flame. Now the chemist was a German, and having been brought up in that land of stoves, probably had not per- 
formed an experiment so easily made in the home of open fires. So he rashly answered, "It does not burn blue, it is impossible, sodium-salts give a yellow flame." On this my friend fetched the salt and threw a handful on to the glowing coals-with the result that the eminent chemist rose up and fled in silence from the room. He gave an admirable example of how not to behave. He ought not in the first place to have denied the fact a priori, and when he was convicted he should have been glad to learn.

It has been said that in scientific work accuracy is the most valuable quality and the hardest to attain. Accuracy alone may strike us as a dull quality to be so highly rated. When a given result has been obtained in eleven successive experiments, and fails on the twelfth occasion, it is the accurate-minded man who makes a wise use of the failure. It' ought to arouse in us a flame of curiosity, lighting in us a whole posse of theories, which force us to vary our procedure and finally enable us to solve the difficulty.

Most of us are inclined to treat an unexpected result in a cavalier spirit, pushing it aside as "only an exception," whereas it should be received as possibly a personage of distinction in disguise, and not as a rude disturber of our pet ideas.

A class of experimentalists exists from whom we all suffer-namely, cooks. How happy we should be if they possessed this lively desire to understand their own lapses from good cookery! It may be urged in excuse, that although the essence of cooking is the application of heat to food, 
not one cook in a thousand has a thermometer in her oven. I hope that some of the ladies who have in these laboratories learned to believe in accuracy, will become missionaries among the ignorant and insist on this simple reform.

There is a type of accuracy of a very different kind which may become an actual vice. For instance, the desire to weigh things to I-10 $\mathrm{mg}$. which should only have been weighed to a centigram, measuring to $\mathrm{I}-10 \mathrm{~mm}$., and calculating averages to several places of decimals. In such a science, as Botany this may be positive waste of time. Sachs, the great German botanist, in whose laboratory I worked, was never tired of complaining of this "sogenannte Genauigkeit," (this so-called accuracy). I am told that Lord Rayleigh, whose physical inquiries demand in some cases excessive and minute accuracy, has a wonderful instinct for knowing when and where he may relax his methods.

I have been compelled to use the words 'science' and 'scientific' because these terms have become firmly adherent to a group of subjects such as Physics, Chemistry, Geology, Botany, etc., and cannot now be detached from them. Unfortunately 'scientific' is used in anothersenseasimplying accuracy of experimental method and in deduction from results. So that in calling ourselves scientific men we run the risk of seeming to claim a monopoly of method, as though we pretended to be somehow superior to the trained workers in other branches. The current use of the word seems therefore to cast unjust suspicion on literature. I wish that 
the word science could be restored to its original meaning of knowledge, or the art of knowing; but words (like organisms) are evolved, and against evolution the gods fight in vain. In any case I hope it will be believed that in speaking of knowledge I have taken instances from what is usually called science, not out of disrespect to literature, but like Dr. Johnson in a different affair -from ignorance.

I imagine Dr. Birkbeck to have had no idea that this institution would be so extensively used for preparing people for examinations. I doubt whether he would have liked it, but respect to the pious memory of a founder may be exaggerated, and since there is no getting rid of examinations, the next best thing is to make the art of coaching as little harmful as may be to pupil and teacher. I do not mean to speak slightingly of coaching as a whole, for a great deal of it is only a very skilful way of imparting knowledge, but it will be allowed that some of it is not educative in a broad sense.

You will remember that Mr. Brooke, in Middlemarch, was in the habit of mildly investigating questions which he always threw over because he foresaw they would "carry him too far." I confess to feeling very like Mr. Brooke when I attempt to balance the interests of teacher and student. In that comfortable period, the I sth century, things were all in favour of the teacher. The poet Gray, who was Professor of History at Cambridge, could never decide whether to lecture in Latin or English, and ended by never lecturing at all.

It is now easier to find cases where the teacher 
is the victim and slave of his pupils, and has no time or strength to continue his own education.

This has at least two bad results, and probably more than that number: (1) From want of time for reading the teacher can hardly avoid falling behind in a rapidly progressive subject such as one of the natural sciences, and consequently the University or College that enslaves him is injuring its own property. (2) He has no time to do any original work, and this is even worse for him (and therefore, as before, for the College). He ceases to be on intimate terms with the plants or animals or chemical substances with which he has to deal, and his teaching must necessarily lose that vigour and freshness that comes from first-hand personal knowledge. It is downright cruelty to deny time for research to those who vehemently desire to add something to the fabric of human knowledge.

The hampered teacher reminds me of a certain migratory bird living with clipped wings in a Zoological Garden: when the migrating season came round the unfortunate prisoner started to walk, and was to be seen pressing its breast against the bars at the north end of its pen. I hope that nowadays all Colleges realise that they must not prison their birds, but give them the means of satisfying their natural instinct for fresh and selfgained knowledge. The students are in one way better off than their masters, since laboratory work is generally new to them and has therefore some of the charm of discovery.

In what I have said to-night I have confined myself to Natural Science, in which alone I have 
had experience of teaching or examining. On the literary side of things I am, I fear, a Philistine,or enfant terrible. I belong to that class of persons (which has at least the merit of being very large) who have hardly opened a Greek or Latin book since the day they passed their Little-go.

I grudge the time that is given at school to making small boys groan over books not well suited to them, while French and German are, or were in my day, all but untaught. If I had had good oral teaching in modern languages (such, for instance, as that given at the Perse School in Cambridge) I could forgive my teachers. We should without tears have learned to talk fluently and write correctly in at least one modern language, and for the sake of this I could perhaps have borne the weariness of Greek and Latin grammar. If it were not for the tyranny of examinations, classical teaching might' be put to its proper use, which is not to serve as an instrument of torture, but to enable us to read ancient authors.

I would teach Latin and Greek only to older boys, and by the method in which we all learn a modern language-that is when we have the advantage of being at once teacher and learner. I mean by reading quickly, with a translation if necessary; at first without understanding half of what we read, but gradually picking up words as we go along. This is how I learned to read easy Italian. By the advice of the late Henry Sidgwick I began on a bad Italian translation of a French novel, because such a version, being full of French idioms more or less literally translated, is 
easier than idiomatic Italian. The right book to begin on is a good murder story, such as one of Gaboriau's, which are fortunately to be had in bad Italian. What would an old fashioned teacher of Greek and Latin have said to this! In my own case I feel that the difficulty of reading the classics was good discipline, and so far educational. In Henry Sidgwick's method one is carried along by the detective business, and learns Italian words as a child picks up its own language, by context and re-iteration. It will be said that this method $\mathrm{s}$ not applicable to Latin and Greek, and that even if it were so, it would not be educative. I confess I do not expect my words to sink into the hearts of the teachers of what are unkindly called the dead languages. The great Moloch of examination has constantly to be supplied with human children, to say nothing of grown-up people. Some escape, but how many are reduced to ashes?

I have said nothing about what should have been my theme, namely, the beginning of the College year. To my thinking beginnings have something of the melancholy that seems more appropriate to endings. Sad associations tend to adhere to all that has the quality of periodicity. I for one feel this when spring once more puts on the familiar look with which our childhood and youth seemed to mingle on equal terms, but which upbraids us now we are no longer young.

And in a more work-a-day spirit Monday morning is sad. I think this is so because the conception Next Week is full of the ghosts of dead resolutions. No doubt it was on Monday mornings that Mr. 


\section{TEACHING OF SCIENCE}

Shandy renewed his vow to have the hinge of the parlour door mended, which I think remained unrepaired to the end of the book.

But after all, this gloomy point of view belongs to the onlooker, not to the actors in the rhythm of things. Each particular Monday is a new-born entity, and doubtless feels a pleasureable excitement in its brief life. And to the actual snowdrops and winter aconites that pierce the cold ground, spring is a new and glorious experience. In this academic springtime (which chances to occur in autumn) the onlooker need have no morbid feelings, only perhaps a touch of envy of those whose College life begins to-day. 


\section{XIII}

\section{PICTURESQUE EXPERIMENTS}

To those who have never made experiments on plants it may seem that 'picturesque' is an odd term to apply to laboratory methods. But to an experimentalist the adjective does not seem overstrained. There is not merely the pleasure of seeing a prediction verified-that may be experienced in more everyday matters. There is a peculiar delight in the discovery of a method of revealing some detail in the natural history of living things. I remember vividly the pleasure which I felt when I first tried the experiment on Sorghum, described in the essay on the Movements of Plants in this volume. ${ }^{1}$ I hoped that the seedlings would curve in the elaborate manner shown in Fig. 4. But I had so little expectation of success that I did not explain the object of the trial to my laboratory assistant, and it came as a shock of delight when he told me that the seedlings had "curled up like corkscrews." I do not think that it is an exaggeration to say, that this result is a picturesque illustration of the distribution of gravitational sensitiveness in plants. The instances in the present essay are not concerned with the movements of plants, and are so far less interesting, but I think the reader will not refuse them the same adjective.

1 See p. 50. 
We all know that in plants-from the smallest weed to the giant trees of America-there flows a stream of water from the root to the topmost leaf. Nevertheless, it is an experience to have ocular proof of this life-giving current. A branch of laurel is so arranged that it has to suck up the water it needs through a coarse thermometer tube, dipping into a beaker. The laurel does not wither, and we know therefore that it is continuously supplied with water. If the beaker is removed we shall see the absorption, for the thermometer tube does not remain full of water; a minute column of air is seen at its lower end which rapidly increases in size, and finally when the tube is emptied of its water-content, bubbles of air escape one after another into the larger tube, which contains the cut end of the branch. This, the simplest possible experiment, is nevertheless a vivid ocular proof of the laurel's power of absorbing water. It can be shown that the sucking power of the branch depends on its leaves, for if these are removed the rate of the current is very greatly diminished. It can also be proved that it depends on some quality of the leaf surface, for if a new specimen is taken, and if the lower sides of its leaves are rubbed with vaseline, the rate of absorption will be seen to diminish very greatly. Greasing the upper surface of the leaves does not produce this result, and when we examine the two surfaces it is found that the lower one is riddled with innumerable microscopic holes (stomata), while the upper side of the leaf has no such apertures. The stomata in fact are the arbiters of what shall pass in or out of the body of the leaf ; 
they are the gate-keepers who regulate both export and import. They are known by actual inspection (with a microscope) to close at night: the result of this is that the evaporation of the leaves is much slower at night, and this is true when allowance has been made for the fact that evaporation is also checked at night by the dampness of the air.

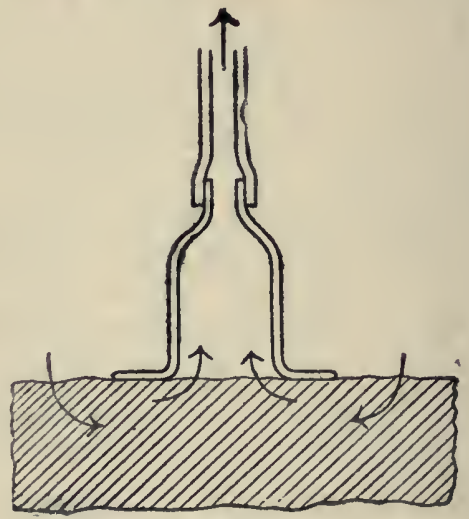

Fig. 7 .

The microscopical inspection of stomata is not a completely satisfactory method of discovering to what degree they are open. It has, however, been my good fortune to resuscitate and simplify a method of studying the stomatal condition. The method was many years ago tried in a hopelessly cumbersome form by a German, but never came into use. My apparatus is described in the Proceedings of the Royal Society, ${ }^{1}$ and is known as the

1 A new method of estimating the aperture of stomata. B., Vol. 84, 1911 . 
Porometer. Its essential part is shown in Fig. 7 . It consists of a funnel-shaped tube, having a broad flange, which is cemented on to the stomata-bearing surface of a leaf. The leaf is represented by the obliquely shaded object and is enormously magnified. To the upper orifice of the funnel is fixed a rubber tube, and by means of it steady suction can be supplied. The result is that a current of air is drawn through the stomata into the leaf, and

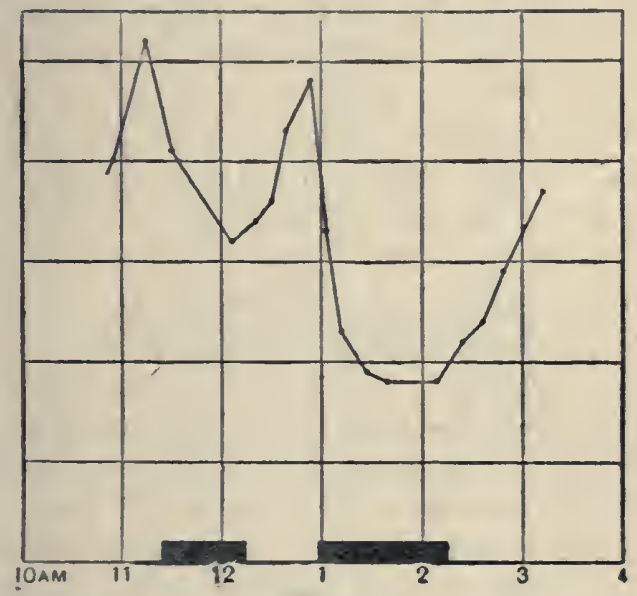

FIG. 8 .

Curve of Porometer readings in light and darkness (black).

then out of the leaf into the cavity of the porometer. The rate of this current is an index of the degree to which the stomata are open. With this apparatus a number of interesting points can be determined.

Fig. 8 shows the effect of alternate periods of light and darkness. The fall of the curve represents 
partial closure, and is seen to occur in the periods of darkness (black), and to rise when the plant is re-illumined. These changes are necessarily accompanied by rise and fall in the evaporation of the leaf, but into the question of the accuracy of this correlation I shall not enter.

There are other methods of demonstrating the movements of the stomata. Stahl had the happy inspiration of making use of the colour-changes of cobalt chloride. A piece of filter paper soaked in a 5 p.c. solution of this salt is blue when dried, and turns pink in damp air. A dry piece of this material, applied with proper precaution to the stomata-bearing surface of a leaf, rapidly changes to pink if the stomata are open. When, however, the same trial is made on the upper surface of a leaf, where stomata do not occur, no such change occurs. If two leaves are treated at the same time, one in the normal position and the other upside down, it is delightful to watch the appearance of a pink picture of that leaf whose stomatic surface is in contact with the paper, while no such change takes place over that which exposes no stomata to the tell-tale material. Another method was discovered by the accident of finding in an old house in Wales a Chinese figure of a man, cut out of a thin shaving of horn, which writhed and twisted when placed on the hand. It was clearly very sensitive to moisture, and it seemed possible that horn-shavings might be used to test the condition of the stomata. The first difficulty was to obtain a supply of this material. Having discovered from the P.O. Directory that there were two horn- 
pressers in London I proceeded to visit one of them somewhere in Hoxton. He turned out to be of a highly suspicious disposition, but his wife had more discernment, and persuaded him that I was a harmless customer, with no designs on trade secrets, and I finally obtained what I wanted. A delicate strip of horn was fixed to a little block of cork and placed on a leaf, and to my delight showed the stomata to be open by violently curving upwards. It was only necessary to fix a graduated arc to the cork, and to fasten a delicate hair on to the horn so as to serve as index. The instrument is not of course accurately quantitative, but it does at least show whether the stomata are nearly shut, moderately open, or widely so. Rough as it is I found it good enough for determining a number of interesting facts in the physiology of stomata. ${ }^{1}$

I now pass on to a different subject, the allimportant proceśs on which the life of green plants depends, an act therefore by which our own existence and that of all other animals is conditioned. I mean the process known as assimilation. This is the truly miraculous feat of using as a source of food the carbonic acid gas $\left(\mathrm{C}_{2} \mathrm{O}_{2}\right)$ which exists in minute quantities in the atmosphere. The plant is in fact a carbon-catching machine, and the machine is driven by the energy of the sun, and can therefore only work in light. The eminent Russian botanist, Timiriazeff, in a lecture on this subject ${ }^{2}$ before the Royal Society, made a witty use of Gulliver's Travels-a book not commonly quoted

${ }^{1}$ Phtl. Trans., B. vol 190, 1898.

2 See above, p. I36. 
as an authority in scientific matters. He pointed out that the philosophers of Lagado, who were extracting sun-beams from cucumbers, were not doing anything absurd. On the contrary, since the cucumbers had been built with the help of sunshine, it was a reasonable expectation that energy corresponding to the sunshine should be obtainable. This indeed is what we do when we drive a steam engine by burning coal which ages ago was built by vegetable machinery driven by sunlight.

It is possible to show the existence of this process by very simple experiments. The most direct, but the least interesting, experiment is to take two similar plants, and expose plant $A$ to an atmosphere containing $\mathrm{CO}_{2}$ while $B$ is in air freed from that gas. Both specimens are placed in bright light, and after a sufficient interval of time their leaves are tested for the presence of starch. This is a simple matter ; the green colouring matter is washed out of them by means of alcohol, and they are then placed in a dilute solution of iodine, which has the property of staining starch purple. It is always pleasant to see the leaf that had been supplied with $\mathrm{CO}_{2}$ turn blue, while the starved leaf remains a hungry yellow.

Some of the prettiest methods of demonstrating this process depend, not on the manufacture of starch in the leaf, but on the fact that an assimilating plant sets free oxygen, by breaking up the molecule $\mathrm{CO}_{2}$, building the carbon (C) into its own tissues, and letting the oxygen (O) go free. A beautiful method was discovered on these lines by Engel- 
mann, which I was never tired of seeing year after year in my Cambridge class. Defibrinated bullock's blood is freed from air by means of an air pump and charged with $\mathrm{CO}_{2}$. In the course of this process it acquires the dingy tint of venous blood. A single leaf of the American weed (Elodea) is mounted on a glass slide in a drop of this blood and covered by an ordinary cover slip. Then comes the dramatic moment : the preparation is exposed to sunshine, and in 3 or 4 minutes a delicate scarlet border begins to appear round the leaf and grows rapidly, making a curious sunset effect in contrast with dingy purple of the venous blood. The meaning is very clear ; the Elodea leaf in sunshine took the carbon from the $\mathrm{CO}_{2}$, and the oxygen thus set free gave the venous blood the scarlet hue characteristic of the arterial condition. Professor Farmer has designed a striking method based on another well-known experiment of Engelmann's. A drop of water containing the products of decay, and therefore swarming with bacteria, supplies the test. A drop of this fluid is placed on a glass slip, one or two delicate leaves of a green water plant (Elodea) are added, and a square of thin glass is placed on it. Round the edges of the cover-slip the preparation must be sealed with a preparation of wax, which melts at a low temperature, and when cold serves to prevent the preparation drying ; it also isolates it from the surrounding atmosphere. After making sure under the microscope that the bacteria are in active movement, the glass slip is placed in the dark for some 3 or 4 hours. It is then examined, and the bacteria will be found to have 
ceased to move because they and the leaves between them have consumed the oxygen dissolved in the water, and bacterial activity being dependent on oxygen naturally came to an end. The preparation is placed under the microscope and illumined with bright incandescent gas, and after a short time the bacteria begin to stir and are soon once more whirling in their insensate dance. The reason is obvious-the green leaves under the influence of light were able to seize the carbon from the $\mathrm{CO}_{2}$, and the $\mathrm{O}$ thus set free put the bacteria in motion. The bacterial dance is therefore evidence of the act of assimilation carried on by the Elodea leaf.

Yet another method is worth mention, viz., that of Boussingault. The plant is placed in an inverted glass vessel resting in a dish of water, and is filled with hydrogen mixed with a percentage of $\mathrm{CO}_{2}$. Inside the vessel a fragment of phosphorus is suspended, and as a small amount of oxygen is sure to be mixed with the hydrogen the phosphorus will be oxygenated and white fumes will fill the vessel. The observer must wait until these clouds have subsided, which may need a couple of hours. This must take place in the dark, and as soon as the atmosphere is clear, the whole preparation is placed in bright light, when obvious clouds will again appear-a proof that oxgyen has been set free by the assimilation of the green plants. With this example I must bring my short series of experiments to a close, with the hope that my readers may not deny that they are picturesque. 


\section{XIV}

\section{DOGS AND DOG LOVERS}

Whately. ${ }^{1}$

Why is it that some people do not like dogs? There are those who dislike other people's dogs just as they dislike strange children. This is a point of view which is comprehensible though unattractive. Still, in comparison with those who do not like dogs at all this class seem positively amiable. I knew a lady with the most perfect understanding of the qualities of human beings, whether bad or good, yet she had no sympathy with dogs. She would be kind to them, as an external duty to all living things, but a dog had absolutely no place in her heart. What made this blindness seem all the more incomprehensible was the fact that she could love a bullfinch ; she could not therefore plead that she loved humanity so much that she had no love left for beings of another sort. After all, it may be that not to care for dogs is no more a blemish than a lack of musical ear, which is not a sign of general dullness of artistic perception since it is found in some poets. We must accordingly allow that not to love dogs is not a sign of a black heart or

${ }^{1}$ Quoted by Professor A. C. Bradley in his Oxford Lectures on Poetry, 1909, p. 34I. 
a debased nature. A dog lover will grant this to be an unavoidable intellectual conclusion, but in the secret corners of his mind he will feel something more hostile than mere Christian pity for these emotionally deformed people. If he holds Erewhonian doctrines he would like to send for the family straightener, and bear with fortitude the punishment inflicted on his friends and relations.

I fear that we, the dog lovers, are, by those who do not share our tastes, held to be unbalanced persons, who intrude their passions on the reasonable and well bred. They object to us as victims of perverted instincts, who talk unknown doglanguage in and out of season. It is not clear to me why we care so much for dogs. Is it, in truth, an exaggeration, or an offshoot of that love of the helpless young of our own kind which natural selection developes in social animals? This is not necessarily maternal, as we see in the story of the heroic male baboon, who risked his life in saving a young one from a pack of baying hounds. ${ }^{1}$ Or is it an instinct developed in a hunting tribe-a blind tendency to take good care of the foodproviders (at the expense of starving aunts and grandmothers), such as we see among the Fuegians, who explained that, "Doggies catch otters-old women no."2

However this may be, it is I think certain that the love of dogs is an unreasoning passion, having all the force of an instinct. In a story by Miss

1 Descent of Man, 1871, Vol. 1., p. 75.

2Charles Darwin's Journal of Researches, etc., ed. 1860, p. 214 
Wilkins we see how the love even of a cat may come to be regarded as a human right or need. The old woman who had lost her cat (he afterwards emerged half starved from the cellar), rebelled against the will of God. She allowed that the happiness of husband and children was possibly not to be expected by everyone, but "there was cats enough to go all round."

I think it impossible to account for the especial affection that we bear to certain dogs. Dogs are, as I have said, in a degree like our children; they come to us and they have to be tended, fed, and guarded, and in these services we learn to love them. And when our affection is reflected back to us from the thing we love, it gains an especially touching quality. In the case of dogs our affection is certainly not a response to any inherent charm obvious to all the world-and here again they resemble childrén. The dog I loved best was an inferior Irish terrier, who gave me much trouble and anxiety. He was constantly fighting; he barked fiercely at innocent visitors. He killed chickens, and for this I had to beat him cruelly, tie him up and leave him trembling with a dead victim round his neck, a punishment for which I still feel remorse, though it saved him from being shot as a criminal, and cured him of his murderous tendency for many years. Pat was not a clever dog, and when striving to learn certain simple tricks he used to fall into abysses of miserable stupidity, and give up all hope of winning the biscuit earned by his fellow-dog, a Scotch terrier, with all the intelligent certainty of his nation. Pat 
had one attractive physical quality; he was perfectly sweet and clean; indeed his adoring family compared his scent to that of new mown hay ; he had also a smooth head, which was compared, by one enthusiastic admirer, to a puttinggreen. He had the attractive and not very common quality of grinning-tucking up his lips and showing the teeth, but producing the effect of a smile, and expressing a shy and apologetic frame of mind.

Pat lived with a bad tempered Scotch terrier called Whisk, whom I liked for his strong character and intellectual acquirements, but I had no great affection for him. He could not bear being spoken to or even looked at while he ate his dinner, and would growl with his mouth full, in a terrific manner, if so disturbed. In the same ferocious spirit he would growl and snap if his basket was accidentally kicked when he was dozing in the evening, and however much we apologised he would take each expression of regret as a fresh insult, and answer them all with growls, which gradually died away in sleep.

We only once had a big dog, and he was not a success though he was an agreeable person. We bought him and his brother, two very fat mastiff puppies, at North Berwick, and brought them south. The one pleasant incident in the journey was the question of a German in Edinburgh station : "Madam, who are these dogs?" We gave away one and kept the other, who bore the magnificent name of Tantallon, soon abbreviated into Tan. He had many friendly habits, but they were on too large a scale for domestic life. He had, for instance, 
a way of placing a dirty paw on the table cloth at meals, and he knocked down street children by trying to lick their faces and (so rumour said) by wagging his tail. He frightened cab horses into hysterics, and their drivers fell off and claimed damages. He ate with enjoyment the embroidered perambulator-cushion of a neighbour, who was discovered looking on while Tan tore strips off the cushion with that powerful upward movement of the head and neck which few cushions can withstand. Finally poor Tan had to be given away, and was lost sight of.

These rough outlines of the characters of some of our dogs are meant to show that the reasons for loving dogs are not patent, and that we cannot complain if the words, used by a little girl in Punch towards a couple of earwigs, should be applied to us and our dogs," "Nasty creatures ! I cannot think how they can care for each other."

Stevenson's essay ${ }^{1}$ on The Character of Dogs is not entirely satisfactory. It is surely a one-sided view of the dog that "he is vainer than man, singularly greedy of notice, singularly intolerant of ridicule, suspicious like the deaf, jealous to the degree of frenzy, and radically devoid of truth." It is hardly possible that he should be vainer than man; and in the dog, vanity is a far simpler and more lovable thing than the complex and offensive passion in his master. His greed for notice and his jealousy are part of his great love for his master. I do not remember that Stevenson ever speaks of

${ }^{1}$ Memories and Porlraits. 
the passionate love (not for mankind, but for one special person) which burns in the heart of a dog. It is a singular omission-and I cannot but think it intentional. If so he was wise, for it certainly does not lend itself to the manner which Stevenson adopts towards dogs. No doubt I may be led into sentimentality and general wearifulness in attempting to describe what seems to me the most striking characteristic of dogs-their great and enduring power of loving. It may be that "the day of an intelligent small dog is passed in the manufacture and laborious communication of falsehood." But he does not lie when he says quite plainly how greatly he loves his master. Nor do I agree that a small spoiled dog would prate interminably, and still about himself. I think he would say, "I love you" rather often, but that bears repetition. I know a Schipperke whose main interest in life is his dinner, but. when his mistress was ill he had only two desires, to lie on her bed and to bite the doctor for approaching her. $\mathrm{He}$ had to be dragged out for a walk instead of eagerly begging for one. Was this an elaborate falsehood? Was it pretence? Was it conventionality?

A dog can hardly be expected to plead guilty when detected in crime. He jumps off the forbidden bed when he hears someone coming, and, being unaware that the warm place on the counterpane will betray him, he assumes a calm and happy air. But this is a lie so natural that I for one cannot blame the liar.

In my life with dogs I have felt much more clearly their desire to speak, and to speak truth, 
than the wish to deceive. I had an old Scotch terrier, who in his youth, before I knew him, had been called Nigel, no doubt because he was black and small, but as he grew up he somehow acquired the uncouth name of Scrubbins. At one stage of his career he was condemned to death for eczema. I begged him off, and he lived some five years with me, and was cured of his eczema by the devoted care of a servant. He was a dog of large heart, who, while he cared for others, was especially devoted to me. In his old age his eyes became dim and his limbs stiff. He had a pathetic way of standing staring into my eyes, or with difficulty getting his paws on to my knees to ask to have his head rubbed, an attention of which he never wearied. No one could doubt that this was his expression of the mutual love that bound us to each other. This was the indestructible impression produced, and it is useless to tell me that he may have been striving to conceal some crime, or at least some base and worldly point of view. When sentiment is applied to facts, rational conclusions are apt to be rare-but without a share of sentiment there might have been no facts to record.

There are innumerable cases proving the devotion of dogs-a passion surviving the master's death, and prolonged until the dog himself dies. Such is the story of the heroic dog seen to watch his master's dead body in South America, keeping the vultures off it, and only allowing himself an occasional rush to the river for water, until he too died. What is there here but-a passion of love? 
We may call it instinct, but what is the love of a human mother?

A dog differs from his master in not taking offence; you may tread on his tail and he will only apologise for being in your way. But I have known a dog bite his mistress when she interfered with him in a fight, while he was beside himself with anger. In the same way an unhappy dog caught in a trap may be so maddened with pain as to attempt to bite those who seek to free him, but these are extreme cases. It is again part of this same lovable quality of dogs that they are not given to moods. They are always ready to welcome us and to wag tails when we notice them.

M. Anatole France shows in some ways a sympathy with dogs, and a sensitiveness to their mental attitudes, finer and more true than anything in Stevenson's essay. The misery of Riquet ${ }^{1}$ over the démenagement of his master, M. Bergeret, is admirably drawn. Riquet begins by barking fiercely when "des hommes inconnus, mal vêtus, injurieux et farouches" invade his beloved house, and ends in being lifted in silent misery and shut up in a portmanteau. Riquet soon becomes too human, but he does at least show his adoration of $\mathrm{M}$. Bergeret, in mourning over the desecration and removal of "ton fauteuil profond-le fauteuil où nous reposions tous les soirs, et bien souvent le matin, à côté l'un de l'autre."

No. xir. of the Pensées de Riquet does not bear on the love that subsists between dog and man;

${ }^{1}$ Crainquebille, Riquet, etc., (n.d.) 


\section{DOGS AND DOG LOVERS}

it goes deeper however, for it shows that men as well as dogs are dominated by instinctive night fears which unite them by a most ancient and enduring bond. Riquet says : "A la tombée de la nuit des puissances malfaisantes rôdent autour de la maison," a fact obvious to all children. There is (No. XII.) an admirable comic prayer to his master beginning, "O mon maître Bergeret, dieu de carnage, je t'adore." But it seems to me to miss the true flavour of doggishness.

Professor A. C. Bradley ${ }^{1}$ strives to show that Shakespeare "did not care for dogs." His opinion is worthy of respect, and all the more that he seems to be a dog lover himself. At least, so I interpret what he says of Shakespeare: "To all that he loved most in men he was blind in dogs, and then we call him universal!" "What is significant," he says, "is the absence of sympathic allusion to the characteristic virtues of dogs, and the abundance of allusions of an insulting kind."

I had always imagined that the description of the hounds in "A Midsummer's Night's Dream" was written by one who liked dogs as individuals, not merely as a picturesque piece of hunting apparatus. But Professor Bradley's contrary opinion is probably the sounder. In the same way I think that the passage in "Lear," "Tray, Blanche, and Sweetheart," etc., could only have been written by one who understood the shock which the little dogs' behaviour gave the King. On the other hand, I agree that Shakespeare does

1 Oxford Lectures on Poetry, 1909, pp. 340, 341. 
not sympathise with the admirable conduct of Launce, who sat in the stocks to save his dog from execution for theft.

Scott was a genuine dog lover. It is on record that he excused himself for not keeping an engagement on the score of the death of an old friend, that friend being his bulldog Camp. His deerhounds Bran and Maida are, like the Duke of Wellington's horse Copenhagen, known to all the world. I am glad to think that Scott's dogs are preserved in several of his portraits. In his books there are two types of dogs, Dandie Dinmonts' Pepper and Mustard who have given their master's name to a breed and are real dogs of flesh and blood. Or again, Harry Bertram's Wasp, who helps to save Dandie from the thieves. But there is also the theatrical dog, Roswal, in The Talisman, who springs at the throat of Conrad of Montserrat and saves his master's honour. Between these come Gurth's dog, Fangs, slightly tinged by the "tushery" of Ivanhoe, but still striking and pathetic. I keep still my sympathy with Gurth, who swears "by S. Edmund, S. Dunstan, S. Withold and S. Edward," that he will never forgive Cedric for having attempted to kill his dog, "the only living creature that ever showed me kindness."

But apart from his love of dogs Scott shows that he can use them with splendid dramatic effect; for instance, when Dugald Dalgetty and the Child of the Mist are escaping from the Duke of Argyll's prison, how we thrill as the distant baying of those deadly trackers, the bloodhounds, strikes on the ear of the fugitives. 
I am not clear as to what was Dickens' personal attitude towards dogs, but he certainly understood the passion of the dog lover.

The man who ousted David Copperfield from the box-seat in the London Coach ${ }^{1}$ remarked, "Orses and dorgs is some men's fancy. They're wittles and drink to me-lodging, wife and children, reading, writing, and 'rithmetic-snuff, tobacker, and sleep." Probably we should have felt, as Mr. Pickwick did on a similar occasion, ${ }^{2}$ that it would have been well if horses and dogs had been 'washing' also. I doubt, in fact, whether we should have enjoyed his company, or even whether we should have felt him a dog lover of our own sort-but we should not be too nice, and must allow some merit to his form of the passion.

Another of Dickens's characters, Mr. Sleary, ${ }^{3}$ of "the Horse Riding," has a much more attractive way of caring for animals. His theory of how a dog he has lost found him again always pleases me. The dog is believed to set on foot inquiries among his friends. "You don't happen to know a person of the name of Sleary, do you? Person of the name of Sleary in the Horse-Riding waystout man-game eye?" The inquiries were successful; and I like, too, the frankly sentimental account of the appearance of the clown's dog after his master's death, and the dog's search for the clown's little girl:-

\section{David Copperfield, Chap. xix.}

2 "Its board and lodging to me, is smoke." Pickwick, Chap. xx.

In Hard Times, Chap. virr. I have ventured to omit the elaborate lisp with which Mr. "Thleary" speaks in the original. 
"We was getting up our Children in the Wood one morning, when there comes into our Ring by the stage door a dog. He had travelled a long way, he was in very bad condition, he was lame, and pretty well blind. He went round to our children, one after another, as if he was a-seeking for a child he knowd ; and then he come to me, and throwed himself up behind, and stood on his two forelegs, weak as he was, and then wagged his tail and died."

I might doubtless give other instances of wellknown men who were lovers of $\operatorname{dogs}^{1}{ }^{1}$ but I shall refrain from further quotation. The instincts of man are being purged of the brutality by which they are too often characterised, and what are clumsily called dumb animals have benefited side by side with human beings. It is not yet true that even a merciful man is merciful to his beast, but in England, at any rate, it is recognised that actual cruelty to animals is wrong, but even this is not always the case among other nations. My father used to tell us how, when his horse was exhausted, he lagged behind his S. American companion who shouted, "Spur him! Don Carlos, spur him! he is my horse," and simply could not understand my father's motive. But I am glad to remember that even among rough people, in uncivilised ages, a sense of humanity to animals was not unknown. Busbecquius $^{2}$ records that in Constantinople an angry crowd assembled before a shop in which

${ }^{1}$ See for instance the Life and Letters of Charles Darwin, Vol I, p. 113.

${ }^{2}$ C. T. Forster's Life and Detters of Ogier de Busbecq, I88ז. 
was exhibited a living bird with its mouth forcibly opened to show its huge gape.

Cruelty is often said to be the outcome of ignorance and stupidity rather than of innate brutality. I wish I could believe this : in any case it is an evil which must be not merely held in check but rooted out. All lovers of animals owe a debt of gratitude to the Society for Prevention of Cruelty to Animals, not only for their great organisation for the prevention and punishment of brutalities, but also, and perhaps especially, for their guidance of public opinion.

THE END.

PRINTED BY W. HEFFER AND SONS LID., CAMBRIDGE, ENGLAND. 


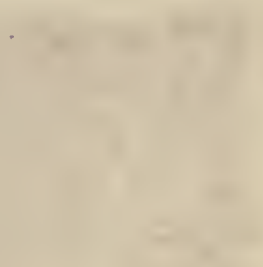

:

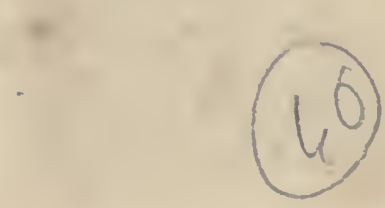

$9 \times 4$

L 



\section{PLEASE DO NOT REMOVE}

CARDS OR SLIPS FROM THIS POCKET

\section{UNIVERSITY OF TORONTO LIBRARY}


